\title{
Modernising English Land Law - Part 2
}

\author{
Graham McBain ${ }^{1,2}$ \\ ${ }^{1}$ Peterhouse, Cambridge, UK \\ ${ }^{2}$ Harvard Law School, USA \\ Correspondence: Graham McBain, 21 Millmead Terrace, Guildford, Surrey GU2 4AT, UK. E-mail: \\ gsmcbain@aol.com
}

Received: January 22, 2019 Accepted: February 28, 2019 Online Published: April 23, 2019

doi:10.5539/ilr.v8n1p85

URL: https://doi.org/10.5539/ilr.v8n1p85

\section{INTRODUCTION}

The first part of this article ${ }^{1}$ considered various pieces of old land legislation which need to be repealed or modernised, in order to assist the intelligibility and coherence of English land law in modern times. This article considers the Norman tenurial system. That is, the feudal system of tenure or land holding ${ }^{2}$ on which our land law has been based since the Norman Conquest in 1066.

\section{(a) Norman Tenurial System}

This article asserts that this tenurial system - that is, this land holding legal system - should be abolished. The result would be that - unlike in times past - title to all land in England and Wales will no longer be held directly or indirectly from the Crown, with the same being the lord paramount (supreme lord). ${ }^{3}$ Thus, all:

- $\quad$ tenures (i.e. feudal forms of landholding); ${ }^{4}$

- $\quad$ tenurial titles (i.e. descriptions of the land holder) ${ }^{5}$

- tenurial incidents(i.e. the rights and obligations deriving from the tenure); ${ }^{6}$ and the

- $\quad$ tenurial hierarchy (i.e. lord paramount, mesne lord and tenant paravail), ${ }^{7}$

\footnotetext{
${ }^{1}$ GS McBain, Modernising English Land Law (2019) International Law Research, vol 8, no 1, pp 30-84.

${ }^{2} \mathrm{C}$ Sweet, A Dictionary of English Law $\left(1^{\text {st }}\right.$ ed, 1882)(tenure) 'Tenure...is a mode of holding or occupying...thus we speak of tenure of land in the sense of occupation or tenancy...'.(italics supplied). E Coke, Institutes of the Laws of England (W Clarke \& Sons, London, last ed, 1824), vol 1, s 1 (1a) 'he [the tenant] has the estate [see n 8] of the land, he holds the land of some superior lord, and is to perform the services due, and thereunto he is bound by doom and judgment of law.' (italics supplied). T Madox, Baronia Anglica: An History of LandHonors and Baronies and of Tenure in Capite (1741), p 163 'Tenure is, where a tenant holdeth of his lord.' (italics supplied). See also C Jessel, The Law of the Manor (1998), $\mathrm{p} 72$.

${ }^{3}$ The holder of the land was the lord (dominus). The Crown was the supreme (i.e. the ultimate) holder, see M Wright, Introduction to the Law of Tenures ( $1^{\text {st }}$ ed, 1730), p 65 'the king as supreme lord of all the lands in England, as were supposed to be due to a supreme lord by the feudal law.'

${ }^{4}$ As will be seen, the principal Norman forms of landholding were: (a) knight service; (b) grand sarjeanty; (c) petty sarjeanty; (d) frankalmoign (including divine service); (e) common socage (which was residual). By 1925 only common socage remained, with (b) and (c) being honorary only. Holding by way of common socage in a borough (burgh, Anglo-Saxon for a fortified town) was called burgage. Tenants of Crown land in the time of Edward the Confessor (1042-66) and of William I (1066-87) were called tenants by ancient demesne and they held by way of common socage. Villeins (peasants, serfs, nativi) in Norman times did not hold their land by way of any tenure, but at will - although, later, by customary law (i.e. the common law as derived from court decision) they were accorded a right to hold land which, later, became called copyhold. There were also slaves, who were treated as chattels without land rights. See also Sweet, $\mathrm{n} 2$, (burgage) and (tenant by ancient demesne). There were various types of villeins - including bordars, cottars (cottagers), soscets, coliberts and regional variations.

${ }^{5}$ Thus, a knight had a tenure by way of knight service (and of grand sarjeanty). A cleric (ecclesiastic) had a tenure by way of frankalmoign. A free tenant (free holder) had a tenure by way of common socage. 'Common' socage was to distinguish the same from socage held by way of local custom. The derivation of socage is uncertain. It may have come from the Anglo-Saxon 'soc', a plough, referring to the performance of agricultural services. However, it may also have derived from the word soke, referring to legal jurisdiction.

${ }^{6}$ Thus, the knight was required to provide military service, a cleric an ecclesiastical service and a free tenant (a socman) an agricultural service. These, soon, became commuted into money payments. Grand and petty sarjeanty were personal services to the sovereign and they were (often) honorary and ceremonial.

${ }^{7}$ An inferior holder of land below the Crown as lord paramount was called a mesne lord (an inferior, or intermediate, lord). Wright, $\mathrm{n} \mathrm{3,p}$ 109 'inferior or mesne lords.' The tenant in actual possession of the land was called the tenant paravail (the inferior tenant).
} 
should be abolished. Such will enable the present concept of an 'estate in fee simple absolute in possession ${ }^{, 8}$ to transmogrify into one of 'ownership' or 'freehold'. This will require amendment to the Law of Property Act 1925, section 1 of which, currently, provides that:

The only estates in land which are capable of subsisting or of being conveyed or created at law ${ }^{9}$ are:

(a) an estate in fee simple absolute in possession; ${ }^{10}$

(b) a term of years absolute. ${ }^{11}$

\section{(b) Legal Concept of the Manor}

As well as the abolition of the Norman system of land tenure, this article advocates the abolition of the legal concept of the 'manor' - including the title 'lord of the manor.' The manor (or landed estate), and any rights and obligations existing in respect thereof, was never part of the Norman tenurial system. Indeed, it was (likely) older, the concept of a manor existing in Anglo-Saxon times.

- However, post-Norman Conquest, there was a degree of inter-connectedness since the lord of the manor was, usually, a knight. Further - like tenurial rights and obligations - there were manorial rights and obligations;

- As it is, today, only a few (genuine) manors still exist. Also, any rights and obligations are few and, in some cases, anomalous. Further, the title 'lord of the manor' can be held in gross and not involve any holding of manorial land.

Thus, it is asserted that this confused area of law should be modernised. That is, the legal concept of a 'manor' including the title 'lord of the manor' and manorial courts - should be abolished. And, such manorial incidents (i.e. rights and obligations) as presently exist should be 'de-linked' from the legal concept of a manor. Thus, they should be held by the registered owner ${ }^{12}$ - not as lord of the manor - but as owner of a freehold (save, where held in gross). ${ }^{13}$ In any case, such manorial incidents should be further limited in their scope.

\section{(c) Crown Franchises often held by Lords of the Manor}

Finally, there are various Crown prerogatives- that is, rights or privileges -which were (sometimes) franchised to lords of the manor as well as to others and which are now (long) obsolete or restricted in their application. ${ }^{14}$ Such comprise the following, the right of the Crown (or a franchisee) to:

\footnotetext{
${ }^{8}$ The 'fee' (also, called a fief or a feud) comprised the (feudal) grant of land (or 'estate'). The terms (conditions) on which the land was granted comprised the 'tenure'. Sweet, n 2, (fee) 'Etymology - Norman French, fee, fe, fie; low latin, feodum, from Gothic, faihu, property (modern German, vieh, cattle). Feodum originally meant land granted in consideration of services to be rendered, as opposed to allodium, or land held absolutely.' Ibid. 'Formerly ' $f e e$ ' also signified the land itself. Thus, a 'knight's fee' was the quantity of land which 'goeth to the livelihood of a knight' and seems to have consisted of lands worth $£ 20$ a year.' Ibid (feud) 'Feud, in the Middle Ages, was a grant of land [an estate] by a feudal superior or lord, to be held by the grantee (the feudal inferior or tenant) in return for services to be rendered by him. The word is used to signify the interest of the tenant, and also the land itself. Etymology - gothic, faihu; Anglo-Saxon, feoh [equals] property.' It may be noted that Littleton (c. 1481) interpreted 'fee' as synonymous with 'inheritance', see Coke, n 2, vol 1, s 12 (a). It is not so interpreted today. See also Ibid, a 1 (9a ) 'feoffment is derived of the word of art feodum, quia est donatio feodi [feud, because [a feoffment] it is the grant of a feud/fee]; for the ancient writers of the law called a feoffment donatio, of the verb do or dedi [I give or I have given].' One suspects that the original word 'feud' referred, in particular, to a grant of land by Lombard sovereigns for military service, with the grant, later, becoming inheritable. See R Chambers, Treatise on Estates and Tenures (1824), introduction, pp 8-10. As to the (mis) interpretation of Littelton, see Ibid, p 25.

${ }^{9}$ This older wording might be altered to state 'The only estates in land which are capable of existing or being created at law...'. There would seem to be no need to refer to a conveyance (a grant, viz. 'being conveyed') as such. Further, 'existing' would seem better than 'subsisting'.

${ }^{10}$ Thus, the estate (the land) was one of a fee (a grant) that was 'simple'. That is, it was absolute (pure) - as opposed to being a conditional or qualified (i.e. a base) fee. The fee was also 'in possession' since it was an outright grant of the seisin (possession) of the land - as opposed to any charge over (or interest in) the same. Coke, $\mathrm{n} 2$, vol 1, s 1 (1b ) 'this word (simple) properly excludes both conditions and limitations, that defeat or abridge the fee.' For seisin, ibid, s 10 (17a) 'seisitus, comes of the French word seisin i.e. possession, saving that in the common law, seised or seisin is properly applied to freehold, and possessed or possession properly to goods and chattels; although sometime the one is used instead of the other.'

${ }^{11}$ i.e. leasehold.

${ }^{12}$ Various manorial rights and obligations are subject to registration under the Land Registration Act 2002.

${ }^{13}$ Some manorial rights and obligations such as common of pasture can be held in gross and are not subject to any landholding by the holder of the same. See n 1, p 35, n 29.

${ }^{14}$ For articles which analyse these in detail, see the following by GS McBain: (a) Modernising the Monarchy in Legal Terms (2010) King's Law Journal ('KLJ'), vol 21(3), pp 535-60 (royal fish); (b) Modernising the Monarchy in Legal Terms - Part 2 (2011) KLJ, vol 22(1), pp 95-118 (royal mines); (c) Abolishing some more Obsolete Crown Prerogatives (2011) Liverpool Law Review, vol 32, pp 65-92 (waif, estray, swans, pontage and murage); (d) Modernising the Monarchy in Legal Terms - Part 3 (2012) KLJ, vol 23, pp 95-118 (treasure trove); (e) Abolishing some more Obsolete Crown Prerogatives: Part 2 (2011) Liverpool Law Review, vol 32, pp 275-315 (wreck, flotsam, jetsam, ligan as well as markets and fairs); (f) Modernising the Monarchy in Legal Terms. Part 4 (2012) 23 KLJ, pp 285-311 (Crown exercise of
} 
- waif (i.e. stolen goods thrown away by a thief in flight); ${ }^{15}$

- estray (i.e. farm animals straying in a manor whose owner is unknown); ${ }^{16}$

- $\quad$ royal fish (i.e. a right to whales and sturgeon) ${ }^{17}$

- royal fowl (i.e. a right to unmarked mute swans in open water); ${ }^{18}$

- $\quad$ wreck (as well as flotsam, jetsam, ligan and derelict) $;^{19}$

- treasure trove. $^{20}$

The Crown prerogatives in the case of waif, estray and royal fish should be abolished in their entirety, being obsolete. In the case of royal fowl, any franchise should be limited only to those still exercising it. ${ }^{21}$ In the case of wreck and treasure trove, any franchise should be abolished. Not least, in the case of wreck, since it has become an obligation rather than a source of revenue (as intended).Also, some lords of the manor - as well as others - in the past were given the franchise of the Crown prerogative to impose a toll (a tax) for the maintenance and repair of defensive walls in towns as well as for the maintenance and repair of bridges and roads. However, such are no longer availed of, being superceded by legislation. Thus, the Crown prerogative (and any franchise) to levy:

- murage (i.e. a toll to maintain, and repair, a defensive wall); ${ }^{22}$

- pontage (i.e. a toll to maintain, and repair, a bridge) ${ }^{23}$

- toll thorough (i.e. a toll to maintain, and repair, a public highway); and

- toll traverse (i.e. a toll to maintain, and repair, a road), ${ }^{24}$

should be abolished. Finally, some lords of the manor (as well as others) in the past were given the franchise to operate a ferry or a fair or market. However, such a prerogative (and any franchise) has been superceded by legislation today or it is not availed of. Thus, the Crown prerogative (and any franchise) to operate a:

- ferry; or a

- fair or market,

should be abolished (which will also, abolish the right to levy any tolls in relation thereto). In conclusion, this article proposes that all these changes should be reflected in a Land Reform Act.

This can be fairly simple in purport, see Appendix A.

these prerogatives); (g) Abolishing the Crime of Public Nuisance and Modernising that of Public Indecency (2017) International Law Research, vol 6, no 1, pp 1-107 (it deals, in part, with the history of bridges and pontage as well as the history of highways); (g) Expanding Democracy - Transferring the Crown Prerogative to Parliament (2014) Review of European Studies, vol 6, no 1, pp 1- 44.

${ }^{15}$ This was prior to the establishment of a modern police force in Victorian times and this right was linked to the legal obligation of hue and cry, itself, long obsolete. The last case of waif was, possibly, in 1600. See also McBain, n 14(c).

${ }^{16}$ This occurred in medieval times when arable land and meadows were open and not inclosed. Thus, the boundaries between land owners were indistinct. However, this right has long been obsolete in practice. Further, such a right occurring would be most unlikely today when fields are fenced, land ownership is clear, farm animals are micro chipped etc. See also McBain, n 14(c).

${ }^{17}$ Sweet, $\mathrm{n} 2$ (royal fish) 'Royal fish are whale and sturgeon, and these, when either thrown ashore or caught near the coast, are the property of the king.' The Crown (the sovereign) indicated in 1971 that she no longer wanted to exercise this right. However, it was preserved by the Wildlife and Countryside Act 1971, s 1. There is no evidence that any franchisee of this right has sought to exercise it in modern times. Besides, whales and sturgeon are protected species.

${ }^{18}$ The Crown only exercises this right on the river Thames, on an annual basis. The only franchisees still extant are the Worshipful Company of Vintners and the Worshipful Company of Dyers, on the river Thames. Further, the Illchester family maintains a swan breeding centre in Abbotswood, Dorest. Swans are no longer eaten by the Crown (or any franchisee) as a delicacy - the purpose for which the right was first recognised.

${ }^{19}$ Modern salvage techniques and the construction and greater safety of ships, have reduced the prospect of wreck in practice. See also McBain, n 14 (e).

${ }^{20}$ There is also a Crown right to dig for treasure trove on Crown land. See also McBain, $n$ 14(d).

${ }^{21}$ See $\mathrm{n} 18$.

${ }^{22}$ See also McBain, $\mathrm{n} 14$, article (c)(pontage and murage).

${ }^{23}$ Ibid.

${ }^{24}$ J Williams, Rights of Common and Other Prescriptive Rights (1880), p 299 'Toll traverse is properly where a man pays a certain toll for passing over the soil of another man, in a way which is not a high street. Toll thorough is properly where a toll is taken of men for passing through a vill in the high street, or passing over a public ferry or a public bridge.' 


\section{LEGAL TEXTS \& DATA}

When considering the Norman system of tenure (i.e. the Norman land holding system), there are many older legal texts on the same ${ }^{25}$ - as well as texts on legal history. ${ }^{26} \mathrm{Also}$, texts on the particular forms of tenure such as: knight service, ${ }^{27}$ sarjeanty, ${ }^{28}$ frankalmoign etc ${ }^{29}$ Further, there are early general texts such as those of Coke $(1628-41)^{30}$ and of Blackstone (1765-9) ${ }^{31}$ which consider the Norman tenurial system. Finally, there are also more modern texts on land law. ${ }^{32}$ This article will commence with describing the system of tenure which was imposed after the Norman Conquest of England in 1066.

In conclusion, this article will consider the historical nature of the Norman legal system of tenure (land holding) and what remains today.

\section{NORMAN SYSTEM OF TENURE}

When William the Conqueror (William I, 1066-87) invaded England and became sovereign in 1066, it is unclear the extent to which he changed English law from that which prevailed in later Anglo-Saxon times. The modern perception tends to be that this was less than might be supposed. ${ }^{33}$

- Sovereign owns all Land. However, as noted in the first article, it is trite law that William I established the legal proposition (principle) - if not before - that all land in England was held of the sovereign. ${ }^{34}$ In short, if asked by an inquirer who owns England, William I would have (likely) replied to the effect 'I do, all of it.' Thus, all land descended from the Crown; ${ }^{35}$

- Barter System not Money. Further, it is often forgotten the extent to which there was a lack of money in early times. Indeed, in Anglo-Saxon England - quite possibly for some 200 years after the departure of the Romans in $\mathrm{AD} 410$ - there was no coinage (from $\mathrm{AD} 451-620$ ). Further, there was no national coinage until AD 765 with the general use of the penny (apart from in Northumbria). ${ }^{36}$ As a result, commercial transactions were effected mainly by barter - payment being made in the form of cattle, ${ }^{37}$ farm produce, other goods etc. Payment was also made in the form of the performance of services.

\footnotetext{
${ }^{25}$ See generally those listed in A Legal Bibliography of the British Commonwealth (1955)('Sweet \& Maxwell'), vol 1 (English Law to 1800), pt 16 (tenures). See, in particular: (a) J Dalrymple, Essay towards a General History of Feudal Property in Great Britain (1 $1^{\text {st }}$ ed, 1757); (b) KE Digby, Introduction to the Law of Real Property (1875); (c) G Gilbert, Law ofTenures (1730); (d) W Holdsworth, Historical Introduction to the Land Laws (1927); (e) PH Hore, Explanation of Ancient Terms and Measures in Land (1874); (f) RC Maclaurin, On the Nature and Evidence of Title to Realty: A Historical Sketch (1901); (g) S Moss, English Land Laws (1886); (h) W Noy, Compleat Lawyer or Treatise concerning Tenures and Estates in Lands of Inheritance for Life and other Hereditaments and Chattels Real and Personal (1651); (i) B Pim, Essay on Feudal Tenures (1871); (j) F Pollock, The Land Laws (1896); (k) P Vinogradoff, Transfer of Land in Old English Law (1907); (1) Wright, n 3. For a pithy summary of the tenurial system, see WE Hearn, The Government of England (1886).

${ }^{26}$ See, in particular: (a) J Fisher, History of Landholding in England (1876); (b) RM Garnier, History of the English Landed Interest (1908); (c) ND Fustel de Coulanges, The Origin of Property in Land (trans. M Ashley, 1904); (d) WF Finlaison, History of Law of Tenures of Land in England (1926); (e) AA Walton, History of the LandedTenures of Great Britain and Ireland from the Norman Conquest (1865).

${ }^{27}$ See, in particular: (a) JF Baldwin, Scutage and Knight Service in England (1897); (b) Madox, n 2; (c) F Phillips, Tenenda non Tollenda or Necessity of Preserving Tenures in Capite and by Knight Service (1660); (d) H Spelman, The Origin, Growth, Propogation of Feuds and Tenures by Knight Service in England (1639). For history, see JH Round, Introduction of Knight-Service into England (1891).

${ }^{28}$ EG Kimball, Serjeanty Tenure in Medieval England (1936).

${ }^{29}$ HM Chew, The English Ecclesiastical Tenants in Chief and Knight Service (1932).

${ }^{30}$ See n 2. Also, E Coke, The Compleat Copyholder (1641) (dealing with copyhold and customary estates, this work is also contained in E Coke, Three Law Tracts (1764)). See also C Watkins, Treatise on Copyholds ( $1^{\text {st }}$ ed 1797, last ed 1826); J Scriven (ed A Brown), A Treatise on the Law ofCopyholds ( ${ }^{\text {st }}$ ed, 1816, last ed 1896); BW Adkin, Copyhold and Other Land Tenures of England (1911) and RB Fisher, A Practical Treatise on the Copyhold Tenure (1794).

${ }^{31}$ W Blackstone, Commentaries on the Laws of England (Oxford, Clarendon Press, $1^{\text {st }}$ ed, 1765-9, Univ. of Chicago Press rep 1979).

${ }^{32}$ See, in particular: (a) C Harpum et al (eds), Megarry and Wade, The Law of Real Property ( ${ }^{\text {th }}$ ed, 2012); (b) SFC Milsom, Historical Foundations of the Common Law ( $\left.2^{\text {nd }} \mathrm{ed}, 1981\right)$; (c) AWB Simpson, An Introduction to the History of the Land Law (2 ${ }^{\text {nd }}$ ed, 1986); (d) EH Burn \& J Cartwright, Cheshire \& Burn's Modern Law of Real Property (18 ${ }^{\text {th }} \mathrm{ed}$, 2011)('Cheshire'); (e) JG Riddall, Land Law (2003).

${ }^{33}$ See e.g. J Hudson, The Oxford History of the Laws of England (OUP, 2012), vol 2, c.990-1216. Madox, n 2, p 27 (writing in 1741) thought that land tenure in Anglo-Saxon times was not feudal.

${ }^{34}$ e.g. Wright, n 3, p 59 'it became a fundamental necessary maxim, principle or fiction of our English law of tenures, that the king is universal lord of his whole territories, and that no man doth [does], or can possess any part thereof, or lands therein, but as either mediately, or immediately derived from him.'

${ }^{35}$ Coke, n 2, vol 1, s 85 (65a) 'first, there is no land in England in the hands of any subject...but it is holden of some lord by some kind of service...Secondly, all the lands within this realm were originally derived from the Crown, and therefore the king is sovereign lord, or lord paramount, either mediate or immediate, of all and every parcel of land within the realm.'

${ }^{36}$ See, on money in the Anglo-Saxon period, GS McBain, Abolishing the Doctrine of Consideration - The Story of the Arra (2018) International Law Research (2018), vol 7, no 1, pp 34-41.

37 'Cattle' (from which the word 'chattels' derives) comprised larger farm animals such as oxen, cows and horses.
} 
Thus, when William I parcelled out English land to his followers in return for their helping him to conquer England - following Continental practice, including in his native Normandy- he instigated a system by which they held their land as tenants (from the latin tenere, to hold) ${ }^{38}$ not in return for the payment of money (rent) but by the tenant having imposed on him a legal obligation to provide various services in return. ${ }^{39}$ These services were also linked to the status of his followers with military service - as might be expected from a conqueror being the most important service which could be rendered to the Crown. ${ }^{40}$ Thus, the hierarchy was as follows, having regard to the status, nature and description of the same:

\begin{tabular}{|c|c|c|}
\hline$\underline{\text { Status }}$ & $\underline{\text { Nature of Service }}$ & Description of Service \\
\hline \multicolumn{3}{|l|}{ Crown } \\
\hline \multirow[t]{3}{*}{ Knight } & Military & Knight service; ${ }^{41}$ \\
\hline & Military $^{42}$ & Grand sarjeanty; ${ }^{43}$ \\
\hline & Military & Petty sarjeanty; ${ }^{44}$ \\
\hline Cleric & Ecclesiastical & Frankalmoign $^{45}$ (inc. divine service) ${ }^{46}$ \\
\hline Socman & Agricultural & Common socage. ${ }^{47}$ \\
\hline
\end{tabular}

\footnotetext{
${ }^{38}$ Harpum, n 32, p 23 'Each of these sets of [feudal] services [e.g. knight service etc] was known as a tenure, because it showed upon what terms the land was held (tenere, to hold)'. See also Coke, n 2, vol 1, s 1 (Co Litt 1a).

${ }^{39}$ Madox, n 2, p 32 'When the king fest [enfeoffed] a man of land, he declared and imposed the service, by which it [the land] was to be holden [held].'
}

${ }^{40}$ In Anglo-Saxon times, it was not wholly different in the sense that subjects were performing military, ecclesiastical and agricultural services. However, these (probably) were not linked to the tenure of land as such.

${ }^{41}$ Riddall, $\mathrm{n} 32, \mathrm{p} 13$ 'A tenant who held by the tenure of knight service was originally obliged to provide his lord with a specified number of fully armed horsemen. By the middle of the twelfth century the obligation to provide men had largely been commuted for a fixed money payment, termed 'scutage'. By the end of the Middle Ages, with the decline in the value of money, scutage had largely ceased to be collected.' See also Simpson, n 32, pp 3, 7-8. One form (type) of knight service was guarding a castle, see Sweet, n 2 (castle-guard or castleward). Another was cornage (blowing a horn to warn of theapproach of the enemy) although this was also (likely) a form of grand sarjeanty. See Sweet, n 2 (cornage). For knights service generally, see Coke, n 2, vol 1, ss 85 (64b) \& 103 (74b). For castleguard, Ibid s 121 (87a) and, for cornage, s 156 (106b). Sweet, n 2 (knight's service) 'Tenure by knight's service was where a man held land of another person or of the Crown by military service, of which the principal varieties were escuage, grand sarjeanty, castleward and cornage.'

${ }^{42}$, Grand sarjeanty included knight's service and it was, usually, of a military nature. See Chambers, n 8, p 209. See also Coke, n 2, vol 1, s $153(105 b-106 a)$

${ }^{43}$ Chambers, $\mathrm{n} 8, \mathrm{p} 13$ (grand sarjeanty) 'A tenant who held by the tenure of grand sarjeanty did so in return for performing some service of an honourable character, e.g. holding an office of state, such as that of chamberlain, or performing a particular service, as at the king's coronation.' Ibid, p 14 (petty serjeanty) 'When the king granted land to a tenant in return for services of a non-personal nature, such as carrying his letters, or feeding his hounds or hawks, or providing him with arrows, or straw for his bed, then the tenant held by the tenure of petty sarjeanty.' Grand sarjeanty included knight's service as it was, usually, a military service of some sort. Ibid, $p$ 209. See also Harpum, $n$ 32, p 24, Cheshire, n 32, p 40 \& Simpson, n 32, pp 9-10, 13-4. See also, generally, Coke, n 2, vol 1, s 153 (105b).

${ }^{44}$ Petty sarjeanty was a more minor military tenure, one of common socage (thus, villeins could not hold it). See generally, Coke, $\mathrm{n} 2$, vol 1 , s 159(108a). Chambers, n 8, pp 210-1 'To socage may be referred tenure by petit serjeanty, that is, by an obligation to pay a bow or arrow, or any other implement of war, to the king. Like grand serjeanty it was exempt from aid and by that distinguished from common socage.' Ibid, p 211 'Grand and petit serjeanty were tenures in capite by their own nature.'

${ }^{45}$ Sweet, $\mathrm{n} 2$ (frankalmoign) 'Frankalmoign is the tenure by which the lands of the church are for the most part held. [quoting Littleton]"And such tenure began first in old time. When a man in old time was seised of certain lands or tenements in his demesne as of fee, and of the same infeoffed an abbot and his co[n]vent, or [a] prior and his co[n]vent, to have and to hold to them and their successors in pure and perpetual alms or in frankalmoigne, in such case the tenements were held in frankalmoign.' Tenants in frankalmoign do no fealty or other temporal service to their lord, but are only bound to celebrate divine service in accordance with the book of common prayer; and, if they fail to do so, the lord cannot distrain them, but can only complain to their ordinary or visitor.' Ibid. 'Etymology - Norman French, fraunche aumoyne, or aumone, [equals] free alms (because the tenant was free from the temporal service).' See also Coke, n 2, vol 1, s 85 (64b) and s $133(93 b)$

${ }^{46}$ See Harpum, n 32, p 24, Riddall, n 32, p 13 \& Simpson, n 32, p 10. Sweet n 2 (tenure by divine service) 'Tenure by divine service is where an ecclesiastical corporation, sole or aggregate, holds land by a certain divine service, as to say prayers on a certain day in every year, 'or to distribute in alms to a hundred poor men an [a] hundred pence at such a day.' This tenure differs from frankalmoign in the service being certain, in consequence of which the lord may distrain if the service is not performed. Fealty is also due by the tenant.' See also Coke, n 2, vol 1, s 85 (64b) ands 137 (96b). Divine service was (originally) called tenure in alms to distinguish it from tenure in free alms (frankalmoign).

${ }^{47}$ Chambers, $\mathrm{n} 8, \mathrm{p} 14$ (commons socage) 'The service most commonly rendered under this form of tenure was of an agricultural character, both the nature (e.g. ploughing) and the amount (e.g. 20 days a year) being fixed. But the services were not necessarily of an agricultural nature, and many other kinds are recorded. In towns a form of common socage existed under which money rents were rendered instead of services.' Coke, n 2, vol 1, s 85 (64b) 'Socage, the service of the plough, aptly placed next to knights service, for that the ploughman makes the best soldier...'. See generally, s 117 (85b). 
It may be noted that the socman (also, called the free tenant or free holder) was a residual category of land holder. There were variants to the same. Especially, burgage where payment in money by townspeople was the primary obligation in lieu of their rendering an agricultural service. ${ }^{48}$

As it is, in time, all these service obligations became commuted into the payment of money, since the latter was much easier. ${ }^{49}$ Such, also, enabled the sovereign to procure professional mercenaries in the case of the military tenure - ensuring a greater chance of attendance and of success in war. Below these categories there were two other main categories into which the English population fell: peasants (villeins) and slaves. Indeed, at the time of the Norman Conquest in1066, the majority of the population fell into these latter categories. Slaves had no land rights at all and they were treated as chattels while peasants held their land at will.

- $\quad$ Concept of 'In Capite'. From 1066, landholding tapered greatly with there being only some 1500 or so major landholders in 1086. Such held their land directly of the Crown. That is, in capite. ${ }^{50}$ And, they were bound to the Crown by giving - on the grant of their land - oaths of homage and of fealty. It may be noted that these are not the same as the oath of allegiance. Further, fealty did not apply in the case of frankalmoign; ${ }^{51}$

- Bonds of Homage \& Fealty. Homage created an obligation by the tenant to his lord to render assistance to the latter in return for protection. ${ }^{52}$ Thus, a bond (also, called a ligament or tie) was formed between them. Fealty created an obligation on the part of the tenant to his lord to faithfully perform the service he was obliged to perform; ${ }^{53}$

- $\quad$ Feudal Hierarchy. Landowners in capite (see above) parcelled out parts of the land they held from the Crown to their followers who, in turn, did likewise - giving oaths of homage and fealty to their superior. The result was to create a system of intermediate landholding with the Crown being termed the 'lord paramount' (that is, the ultimate, or supreme, lord), ${ }^{54}$ the intermediate landholder being termed the

\footnotetext{
${ }^{48}$ Alfred the Great (king of the Anglo-Saxons, 886-899 AD) expanded fortified towns (also called burghs, boroughs), although London had been such with the Romans having erected a great City wall in c. $220 \mathrm{AD}$ (it embraced c. 330 acres within). London town was owned by the king (in his body politic), at least, from the time of king Aldred. In his first charter to the Londoners, c. 1087, William I called them his burgesses (buruwaru). London would have had c. 18,000 citizens at the time of the Norman Conquest 1066 and they (probably) paid to William I a composite rent of c. $£ 300$ p.a. Such was a 'quitrent' since they were quit of any agricultural or other service - apart from an oath of fealty. Certainly, a charter of Henry I (1100-35) ofc. 1132 recognised a quit rent of $£ 300$ p.a. which only formerly ended in Londonin 1929 when the rent was cancelled. See generally, GS McBain, Liberties and Customs of the City of London - Are there any Left ? (2013) International Law Research, vol 2, no 1, pp 32-95. Another variety of common socage was gavelkind. See also Coke, n 2 , vol 1 , s 210 (140a)

${ }^{49}$ Early on the obligation of knight service could beavoided by the making of a money payment in lieu (scutage). This (also, called escuage) was introduced in the reign of Henry I (1100-35). By the end of the fifteenth century, services rendered in payment in connection with common socage had largely been commuted into money payments, sometimes called 'quit rents' (see n 48). However, by the end of the Middle Ages, quit rents had largely ceased to be collected, being nominal. See also Sweet, n 2 (escuage) 'no instance of Parliament's assessing it [escuage] since the reign of Edward II [1307-27].'

${ }^{50}$ Sweet, n 2 (in capite) 'In capite, in chief, or en chef, originally meant 'directly', 'immediately', sine medio, sans mesne. Hence 'tenure in capite' primarily means the tenure of very lord and very tenant, or the relation between a tenant and his immediate feudal superior, as opposed to a mesne tenure; but the phrase was always applied especially to land held directly of the crown, and at the present day it is used exclusively in that sense.' Madox, n 2, p 164 'To hold of the king in capite was to hold of him immediately, sine medio.' Ibid, p 166.

${ }^{51}$ Thus, if the oath of fealty is abolished, this results in no abolition of allegiance (which arises irrespective of an oath in any case). See Coke, n 2, vol 1, s 94 (68b). Also, Chambers, n 8, pp 173-5 (difference between liege homage and feudal homage). As to frankalmoign and no fealty, see Coke, n 2, vol 1, s 135 (95a).

${ }^{52}$ Sweet, n 2 (homage)'homage signified a 'most honourable and humble service of reverence', which every free tenantfor an estate in fee simple or in fee tail was bound to perform to his feudal lord; it was so called because in doing homage in ordinary cases the tenant said to his lord 'I become your man [Norman French home] of life and limb'. Homage created an obligation of assistance by the tenant to his lord, and of protection by the lord to his tenant. It was abolished by the Tenures Abolition Act 1660. See E Jenks, Modern Land Law (1899), p 15, $\mathrm{n} 2$. See generally (inc. for the oath of homage), Coke, n 2, vol 1, s 85 (Co Litt 64a). Also, Cheshire, n 32, p 33 \& Simpson, n 32, pp 15-6.

${ }^{53} \mathrm{Ibid}$, (fealty) 'Fealty is a service which every free tenant (except a tenant in frankalmoign) is in theory bound to perform to his feudal lord. It is therefore an incident to every seignory and is due on every change of the tenancy or the seignory; but it is in practice completely obsolete. The ceremony of fealty consisted in the tenant taking an oath of fidelity to the lord. Fealty is also one of the incidents of tenure due from every copyhold tenant to the lord of the manor in respect of his customary tenement. It consists in swearing to be faithful in performing the services of the tenancy, and may be required on every change of the lord or tenant; but in practice it is always respited.' Also 'Etymology - Norman French: From Latin fidelitas, faithfulness.' See generally, Coke, n 2, vol 1, s 91 (67b).

${ }^{54} \mathrm{Ibid}$, (paramount) 'Paramount means superior...In the law of tenure, if A holds land in fee of B and B holds the same land in fee of C, then $\mathrm{C}$ is the lord paramount, and he has the seignory paramount, as opposed to A the tenant paravail, and B the mesne, whose seignory is called the mesnalty.' Ibid, (paravail) 'paravail means inferior or subordinate...The term is chiefly used with reference to the tenure of estates in land, a tenant paravail being a tenant who holds land in fee of another and has no tenant who holds of him...'
} 
'mesne lord' (that is, the intermediate lord) ${ }^{55}$ and the person actually in possession of the land in question being termed the tenant paravail (that is, the inferior tenant) ${ }^{56}$ In the case of the intermediate landholder, there could be one, or more, of the same; ${ }^{57}$

- $\quad$ Seignory. The relationship between the feudal lord and the tenant was termed one of 'seignory' (also, called 'lordship' $)$; $^{58}$

- Manors \& Honors. The Norman tenurial system was, also, one where land not inside a town (that is, a burgh or borough) ${ }^{59}$ was, generally, described as a 'manor' from the latin manerium (itself, from the latin manere, to remain), ${ }^{60}$ much as we refer to a landed estate or a 'farm' today. ${ }^{61}$ Such a term was, originally, a non-technical description. On his manor (landed estate) the lord (dominus) farmed it with the help of his family as well as with the help of slaves, villeins (peasants) and free tenants, all of the same living on (and from) the land. The lord was called the 'lord of the manor.' An honor (also spelt honour and, also, called a barony) comprised a description of a group of manors held by the same person. $^{62}$

Further, the Norman tenurial system could be one of 'substitution' or of 'subinfeudation'.

- In the first case, the tenurial incidents (that is, the rights and obligations flowing from the tenure) were held of the Crown. Thus, for example, if the Crown (A), conveyed (i.e. granted) land to B who granted it to $\mathrm{C}$, any tenurial obligations became owed by $\mathrm{C}$ to $\mathrm{A}$;

- Contrariwise, with subinfeudation, they were owed to B who, then, owed them to A.

The problem with the latter was that the Crown and the greater landowners lost out, since the service obligation (and later payment in lieu) became 'lost' among a mass of intermediate mesne lords. Thus, subinfeudation of the fee simple was prohibited by the Statute of Quia Emptores 1290, as discussed in the first article. ${ }^{63}$ As well as these major service obligations, there were a whole host of other obligations which were connected to landholding such as marriage, wardship, relief, aid etc. ${ }^{64}$ These are not considered in any detail in this article since they were abolished by the Tenures Abolition Act 1660.

\footnotetext{
${ }^{55}$ Ibid, (mesne) 'signifies middle, intervening or intermediate'. Ibid, 'Etymology - Norman French, meen; modern French, moyen, from late Latin, medianus, from medius, middle.'

${ }^{56}$ Ibid, (lord) 'If before the Statute of Quia Emptores [1290] A conveyed land to B to hold of himself (A) and B conveyed it to C to hold of himself (B) A would be called lord paramount, B mesne lord, or 'mesne' and C tenant paravail...the Crown is sovereign lord, or lord paramount, of all the land in England, and in that character sometimes becomes entitled to land by escheat.' Ibid, (paravail) 'paravail means inferior or subordinate... The term is chiefly used with reference to the tenure of estates in land, a tenant paravail being a tenant who holds land in fee of another and has no tenant who holds of him, as opposed to a mesne lord and a lord paramount.' Also 'Etymology Notwithstanding Coke, who says that 'the tenant of the land is called tenant par availe, because it is presumed that he hath availe and profit by the land', it seems clear that paravail is compounded of par and the French word aval [equals] below, and paramount of par and amount [equals] above.'

${ }^{57}$ Ibid (lord) 'In the law of real property, a lord is a person of whom land is held by another as his tenant.... If, before the Statute of Quia Emptores [1290], A conveyed land to B to hold of himself (A), and B conveyed it to C to hold of himself, A would be called lord paramount, $\mathrm{B}$ mesne lord, or 'mesne', and $\mathrm{C}$ tenant paravail.'

${ }^{58}$ Ibid, (seignory) 'A seignory is the relation of a feudal lord to his tenant, and to the land held by him. Thus, if before the Statute of Quia Emptores [1290], A, a tenant in fee simple, conveyed his land to B to hold of A as his tenant, then A's rights against B in respect of services, fealty etc, and his interest in the land in the event of an escheat or forfeiture by B or his successors in title, would constitute a seignory. Since the Statute of Quia Emptores no seignory can be created.' Also 'Etymology - Norman French, seigneur; from Latin, senior.'

${ }^{59}$ This being the Anglo-Saxon word for a fortified town. See also ns $4 \& 48$.

${ }^{60}$ See Jessel, n 2, p xi.

${ }^{61}$ The word 'farm', likely, derives (at base) from the latin 'fundus' which referred, in Roman times, to private land as opposed to that owned by the State. See also n 125. In Anglo-Saxon times, the word 'farm' is traced to the Anglo-Saxon 'feorme' (farm), the food rent payable by a tenant, since coinage was rare. As to coinage, see McBain, $\mathrm{n} 36$.

${ }^{62}$ Sweet, $\mathrm{n} 2$, (honor) 'Honor means (i) a seignory in capite of which several inferior lordships or manors depend; and (ii) the land or district included in the seignory. An honor cannot be created since the Stat [ute] Quia Emptores [1290], except by Act of Parliament.' See also GS McBain, The Case for abolishing Manorial Franchises and Customs (2013) Coventry LJ, vol 18, no 1, pp 43-68. Also, Madox, n 2, p 3.Halsbury, Laws of England ( $5^{\text {th }}$ ed)( 'Halsbury Laws'), vol 32, para 96 'If the land allotted to a subject by the monarch was sufficiently large to allow of his subordinates in their turn constituting other manors within the parcels allotted to them, the subject, who was called a 'tenant in capite' or a 'lord paramount', was said to have an 'honour', or in some cases a 'barony', and his subordinates were inferior lords or 'mesne lords'.

${ }^{63}$ Ibid (lord) 'The Statute of Quia Emptores [1290] having abolished subinfeudation, no person can now create a lordship. The only lords of any importance at the present day are lords of manors. But the Crown is sovereign lord, or lord paramount, of all the land in England, and in that character sometimes becomes entitled to land by escheat.'

${ }^{64}$ e.g. knight service had 5 incidents (aids, relief, wardship, marriage, escheat), see Sweet, n 2 (knight service). See generally, Coke, n 2, vol 1, s 103 (76a). Also, Sweet, n 2 (definitions of the same).
} 
In conclusion, the Norman kings instituted a legal system of tenure (land holding) in which all land was held directly - or indirectly - of the Crown in return for providing a service, whether military, ecclesiastical or agricultural.

\section{TRANSITION IN THE TENURIAL SYSTEM}

In the course of time, the Norman tenurial system changed. The principal change was that the service obligation became commuted into the payment of money, as the latter became more plentiful. This commenced from the reign of Henry I (1100-35).

- Thus, instead of providing knight service, the knight paid a sum of money in lieu. It was called escuage or scutage. ${ }^{65}$ This enabled the sovereign to employ professional mercenaries instead;

- In the cases of grand sarjeanty and frankalmoign, these tended to be fairly nominal anyway and the latter soon became limited to coronation services. In the case of petty sarjeanty this, also, soon became nominal;

- In the case of socage, at the time of the Norman Conquest 1066, this involved the performance of various agricultural services. However, in the case of free tenants who were located in towns it became commuted into the payment of (often) an annual composite rent. This was also (often) in the form of a quitrent. That is, the free tenants were held 'quit' (free) of all service obligations in return for a money payment termed a 'rent' (return); ${ }^{66}$

- In conclusion, the 'service' system of tenure evolved into that of a money payment (a rent) ${ }^{67}$ in lieu. A process of commutation. This process (likely) commenced with townspeople in large towns such as London who paid a rent, possibly, at the time of the Norman Conquest or not long thereafter. ${ }^{68}$

Also, the peasants (villeins) who worked on the manor of another - and who held the land on which they lived wholly at the will of the former - began to acquire, in law, a customary right to retain that land and to pass it on (on the same terms) to their children. Thus, villein tenure became - in the course of time - what was called copyhold tenure. That is, a landholding that was evidenced by reference to a copy of the relevant manorial court roll. ${ }^{69}$ The source of this 'custom' - viz. common (that is, customary) law - comprised (evolving) judicial precedent. As for slaves, they had 'died out'in England by the $13^{\text {th }}$ century or so, graduating to becoming peasants (villeins) or free tenants. ${ }^{70}$ As a result, by later medieval times, the Norman tenurial system was 'creaking'. Indeed, it should have been overhauled in the $16^{\text {th }}$ century - if not before - with a money payment system wholly superceding it. ${ }^{71}$

In conclusion, the Norman tenurial system - one which was based on holding land in return for the performance of a service - had become obsolete by later medieval times.

\section{TENURES ABOLITION ACT 1660}

The failure to reform the Norman tenurial system created problems for sovereigns such as Henry VIII (1509-47) who was perpetually short of money. So too, for his successors. It became chronic in the time of James I (1603-

\footnotetext{
${ }^{65}$ Madox, n 2, p 219 'escuage-money, was a composition or commutation for actual service.'

${ }^{66}$ Sweet, n 2 (rent). See also n 48.

${ }^{67}$ The source of the word 'rent' is not wholly clear. Coke, n 2, vol 1, s 213 (141b) 'rent', 'in latin redditus by some dicitur a redeundo, quia retroit, et quotannis redit. And others say it is derived of reddere, for that the rent is reserved out of the profits of the land, and is not due till the tenant or lessee take the profits.' See also Clun's Case (1613) 10 Co Rep 126a at 127b 'So we call a rent paid yearly for land or other things redditus, a reddendo [a return, from returning], because it is yearly yielded or restored for the lands etc. Or rather as some will have reddeundo [turning back], because it does return to the lessor or donor for the issues and profits of of the land.' JH Baxter \& $\mathrm{C}$ Johnson, Medieval Latin Word-List (1955 reprint) 'rentale, rental, rent-bookc.1200, a 1564; rent (sc) 1528, 1565'. See also Oxford English Dictionary (rent) 'OF [Old French] rente.' Coke, n 2, vol 1, s 119 (86a) 'afterwards these [agricultural] services were changed into money, by the consent of the tenants and the desire of the lords viz. into an annual rent...'. Madox, n 2, p 260 ('the rent was called rent-service, by uniformity of speaking'). See also CT Lewis \& C Short, A Latin Dictionary (1890)(reddo and redeo).

${ }^{68}$ See n 48.

${ }^{69}$ Villein tenure (villeinage), unlike common socage, was an unfree tenure. It became known as copyhold. See Harpum, $\mathrm{n} 32$, pp 25-7. Coke, n 2, vol 1, s 73 (58a) 'Bracton called copyholders villanos sockmannos [i.e. peasants], not because they were bond [bound to the land], but because they held by base tenure, by doing of villain services'. See generally, Ibid, s 172 (116a) et seq. Tenancy by the verge was a form of copyhold, Iibid, s 78 (61a).

${ }^{70}$ Sweet, n 2 (villein) 'Villeinage has never been formally abolished, but it had become rare in Edward the Sixth's reign [1547-53], and disappeared altogether under the Stuarts'. Ibid, 'Etymology - Norman French, vileyn; low latin, villanus, from villa, a farm.' The last case of villeinage appears to have been Pigg v Caley (1617) Noy 27 (74 ER 997). Certainly, the Tenures Abolition Act 1660 abolished villeins appurtenant (i.e. those bound to a manor) but not villeins in gross (i.e. those bound to a particular lord).

${ }^{71}$ Hearn, n 25, p 339 'When Henry Tudor [Henry VII, 1483-1509] ascended the throne, little of feudalism was left save its burthens [burdens].'
} 
25) who resorted to ever more dubious tactics to raise funds - such as creating more knights and then demanding they perform their service obligation. This, in order to secure the payment of money in lieu. ${ }^{72}$ The solution would have been to abolish the Norman tenurial system and for Parliament, instead, to pay the sovereign for undertaking his role by means of an annual payment (salary) to him - with the recovery of such a sum being by way of a national tax - whether on land or on goods (such as on alcohol etc). ${ }^{73}$ The ill-fated Charles I (1625-49) sought to achieve this early on in his reign. However, Parliament was not prepared to accept the same. As a result, it was not until after a bloody Civil War (1641-9) and the Commonwealth period (1649-60) that Charles II (1660-85) was able to agree with Parliament the passing of the Tenures Abolition Act 1660 (the '1660 Act' $).{ }^{74}$ This Act, inter alia, provided as follows, that:

all tenures by knights-service of the king, or of any other person, and by knights service in capite, and by socage in capite of the king, ${ }^{75}$ and the fruits and consequents [i.e. the consequences or incidents] thereof, happened or which shall or may hereafter happen or arise thereupon or thereby, [shall] be taken away and discharged; any law, statute, custom, or usage to the contrary hereof in any wise notwithstanding;

and that all tenures of any honours, manors, lands, tenements or hereditaments, or any estate of any inheritance at the common law, held either of the king, or of any other person or persons, bodies politic or corporate, are hereby enacted to be turned into free and common socage ...

[and] that all tenures hereafter to be created by the king's Majesty, his heirs or successors, upon any gifts or grants of any manors, lands, tenements or hereditaments, of any estate of inheritance at the common law, shall be in free and common socage, and shall be adjudged to be in free and common socage only, and not by knights service or in capite...

and that the same shall for ever hereafter stand and be discharged of all tenure by homage, escuage, ${ }^{76}$ voyages royal ${ }^{77}$ and charges for the same, [as well as] wardships incident to tenure by knight service, and values and forfeitures of marriage, and other charges incident to tenure by knights service, and of and from aide pur file marrier, and aide pur fitz chevalier... ${ }^{78}$ (italics supplied)

Thus, the 1660 Act abolished knight service - whether held directly of the sovereign (in capite) or not.

The Act also provided:

this Act, or any thing therein contained, shall not take away, or be construed to take away, tenures in frank-almoign, or to subject them to any greater or other services than they now are;... ${ }^{79}$

\footnotetext{
${ }^{72}$ The House in Lords proposed, in 1610, that James I be paid $£ 200,000$ p.a. in return for the abolition of some of the tenurial system. However, this was rejected, see e.g. Cobbett's Parliamentary History of England (1806), vol 1, pp 1134 \& 1142. Hearn, n 25, p 341 'the negotiation was ultimately broken off in mutual displeasure.'

${ }^{73}$ In the time of Charles II (1660-85) this was achieved with his receiving a tax on beer and other liquors. Hearn, n 25, p 342.

${ }^{74}$ The Preamble to the Act provided 'Whereas it hath been found by former experience, that....tenures by knights-service, either of the king or others, or by knights service in capite, or socage in capite of the king, the consequents [i.e. the incidents] upon the same, have been much more burdensome, grevious and prejudicial to the kingdom, than they have been beneficial to the king...'.

${ }^{75}$ Grand and petty sarjeanty were both held in capite, see Coke, n 2, vol 1, s 159 (108a). See also s 161 (108b), n (1) re their abolition as tenures by the Tenures Abolition Act 1660 .

${ }^{76}$ Sweet, n 2 (escuage) 'Tenure by escuage was one of the varieties of tenure by knight's service. It imposed on the tenant the duty of accompanying the king to war for forty days, or of sending a substitute, or of paying a sum of money, which was assessed by Parliament after the expedition or 'voyage royal.' [royal war expedition] This payment was called escuage, or escuage uncertain, to distinguish it from escuage certain, which was one of the services of which socage might consist. Thus if a man held land by the service of paying to his lord half a mark, or other fixed sum for escuage, this was escuage certain, and the tenure was socage and not knight's service. Escuage was abolished by [the Tenures Abolition Act 1660], and had fallen into disuse long before, for there is no instance of Parliament's assessing it since the reign of Edward II [1307-27].' It also stated 'Etymology. Norman French, escuage (late latin, scutagium), from escu; latin, scutum, a shield.' See generally, Coke, n 2, vol 1, s 95 (68b) 'Escuage is called in latin scutagium, that is, service of the shield; and that tenant, which holds his land by escuage, holds by knight service'.

${ }^{77}$ Coke, n 2, vol 1, s 95 (69b) 'A voyage royal is not only, when the king himself goes to war...but also when his lieutenant or deputy of his lieutenant goes.'

${ }^{78}$ Sweet, $\mathrm{n} 2$ (aid) 'Formerly every tenant in chivalry was liable to make payments called aids (1) to ransom his lord's person if taken prisoner; (2) to make the lord's eldest son a knight; and (3) to provide a portion for the lord's eldest daughter; and every tenant in socage was liable to the two latter aids. Aids were abolished by [the Tenures Abolition Act 1660].' See also Chambers, n 8, p 190-2.

${ }^{79}$ This reference included divine service. Chambers, $\mathrm{n} 8, \mathrm{p} 217$ 'Tenure by divine service differs from tenure in frank almoign principally in this, that in tenure by divine service, the duty to be performed is always ascertained in the deed by which the tenure was created...It is a consequence of this certainty that the lord may distrain for the non-performance of the service. And it is a further consequence that a tenant by divine service may be compelled to do fealty to the lord, fealty being incident to every service for the neglect of which distress may be made.'
} 
nor to alter or change any tenure by copy of court roll [i.e. copyhold], or other services incident thereto; 80

nor to take away the honorary services of grand sarjeanty, other than that of wardship, marriage, and value of forfeiture of marriage, escuage, voyages royal, and other charges incident to tenure by knights service; and other than aide pur faier fitz chevalier, and aide pur file marrier. (italics supplied)

Thus, the 1660 Act preserved the tenure of frankalmoign. Riddall asserted that such was, then, abolished by the Administration of Justice Act $1925 .^{81}$ Others are not so sure. One would suggest that frankalmoign was abolished as Riddall suggests. However, a Land Reform Act could confirm this, if required (see Appendix A). The 1660 Act also preserved copyhold tenure (tenure by copy of court roll). Finally, the 1660 Act abolished the tenures of grand and petty sarjeanty. ${ }^{82}$ However, it left these as honorary services. That is, the 1660 Act abolished the tenure as such but it preserved certain incidents (rights and obligations) of the same. Albeit, these were left honorary so that they are not legally enforceable as such ${ }^{83}$ It is asserted that these should now be abolished save in respect of grand serjeanty as it relates to coronation services (see7).

In conclusion, the 1660 Act abolished certain tenures and tenural incidents, but not all of them. Thus, frankalmoign remained as a tenure. So did copyhold. Grand and petty sarjeanty also remained, but only as honorary services (that is, they were not legally binding).

\section{NORMAN TENURE IN THE $20^{\mathrm{TH}}$ CENTURY}

Although the 1660 Act abolished much of the Norman tenurial system, parts of it remained. Various pieces of legislation in the $20^{\text {th }}$ century abolished more tenures and tenurial incidents - viz. those relating to: (a) copyhold land; and (b) land held by way of common socage. In respect of these, the position was as follows:

\section{(a) Incidents of Copyhold Tenure}

The Law of Property Act 1922 abolished copyhold tenure. This took effect at the end of $1925{ }^{84}$ However, certain incidents (i.e. rights and obligations) of copyhold remained. Riddall noted that those which survived at that time were divided into 3 classes:

(i) Those in the first class were abolished from 1 January 1926. This class included: fealty (i.e. the obligation of the copyholder to perform his copyhold service), suit of court (i.e. the obligation of the copyholder to attend a court customary) and escheat for want of (that is, for lack of) heirs; ${ }^{85}$

\footnotetext{
${ }^{80}$ Coke, n 2, vol 1, s 73 (57b, Littleton) 'Tenant by copy of court roll is, as if a man be seised of a manor within which manor there is a custom which has been used time out of mind of man, that certain tenants within the same manor have used to have lands and tenements, to hold them and their heirs in fee simple, or fee tail, or for terms of life etc at the will of the lord according to the custom of the manor.' Also, (58a, Coke) 'And for as much as the title or estate of the copyholder is entered into the roll whereof the steward delivers to him a copy thereof he is called copyholder.' Sweet, $\mathrm{n} 2$ (copyhold) 'Copyholds, or lands held by copyhold tenure, are lands, forming part of a manor, originally granted by the lord for tenancies at will merely, which however have by immemorial custom become converted into estates independent of the will of the lord in everything but name, and of various degrees of duration, according to the custom of the particular manor. Copyholds are so called, because the evidence of the title to such lands consists of copies of the court roll of the manor, a book in which all dealings with the land are entered.'

${ }^{81}$ Riddall, n 32, p 21. Jessel, n 2, p 42 'Both frankalmoign and copyhold were converted [into common socage] in 1925.' However, he also stated, p 86 'Frankalmoign was abolished by the Administration of Estates Act 1925 save for those holding at the time, and there can be few (if any) now left.' Ibid, p 315 'Section 56 and sch 2 of the Administration of Estates Act 1925 [rep] provides that all frankalmoign should be converted to socage as from the date of the first transmission after December 31, 1925. By the date of the 1976 Measure [i.e. Endowments and Glebe Measure 1976] there can have been few (if any) church lands where the holder was still the same individual as before 1926, so that by then virtually all frankalmoign must have ceased...' Today, such is (almost certainly) obsolete.

${ }^{82} \mathrm{Ibid}, \mathrm{p} 21$ 'The number of tenures was reduced in two stages...In 1660, by the Tenures Abolition Act, which abolished grand and petty sergeant, and knight service...'?

${ }^{83}$ Ibid, 'Incidents of a tenure which has been abolished, the incidents being expressly preserved by the Act of 1660 which abolished the tenure itself. The following incidents fall into this category: (a) The honorary services of grand sargeanty. These were preserved by the Act of 1660 which abolished the tenure of grand sergeanty. These are of no more than historical interest...'. See also Law of Property Act 1922, s 126 'Nothing in this Act shall affect the services incident to grand and petty sarjeanty (which shall not be deemed to be manorial incidents) but the land affected shall be subject to the provisions of this Act in like manner, as if, before the commencement of the Act, it had been held in free and common socage or has been copyhold land as the case may require.'

${ }^{84}$ See Law of Property Act 1922, s 128 and sch 12, para 1 (rep). Also, Riddall, n 32, p 21. Jessel, n 2, p 91 'copyhold was abolished on December 31, 1925 by the Law of Property Act 1922.'

${ }^{85}$ Riddall, n 32, p 21. Harpum, n 32, pp 33 lists (in more detail): (i) forfeiture for alienation in freehold (i.e. for purporting to convey the copyhold land as freehold) or without licence; (ii) fealty and customary suits and services; (iii) escheat for want [i.e. lack of] of heirs; (iv) special customs of descent (e.g. gavelkind and borough English), dower, freebench (the usual name for dower in copyhold land) and curtesy. In the case of escheat, the Law of Property Act 1922, sch 12 para 1(c) provided that 'In place of the lord's right to escheat [,] the Crown or the duchy of Lancaster or the duchy of Cornwall (as the case may be) may become entitled to the land as bona vacantia under the provisions of [part 8] of this Act.' Part 8 of the Act (relating to intestacy) has been repealed. Harpum, n 32, p 34, fn 74 noted that this para 1(c)
} 
(ii) Those in the second class were abolished at the end of $1935 .{ }^{86}$ However, the lord of the manor was given the right to claim compensation from the tenant for their loss. The date for claiming has long passed. The incidents in this class included the following: relief, forfeiture to the lord, heriots, quit rents, and the right of the lord to timber.

Thus, these no longer exist. As to the third class, Riddall stated:

(iii) Those in the third class were preserved and continue indefinitely unless abolished by agreement between the lord of the manor and the tenant (or by legislation). The incidents in this class include any:

(a)rights of the lord (or tenant) to mines and minerals;

(b) rights of the lord in respect of fairs, markets and sporting; ${ }^{87}$

(c) tenants' rights of common (e.g. to pasture beasts on the waste land of the manor);

(d) liabilityof the lord (or tenant) for the upkeep (i.e. the repair and maintenance) of dykes, ditches, sea walls, bridges and the like. ${ }^{88}$

These incidents in the $3^{\text {rd }}$ class (save for fairs and markets) are manorial incidents - not tenurial ones something, often, confused although they are quite distinct. Those in respect of fairs and markets are franchisal, since they comprise a franchise of the Crown prerogative to operate a market or fair.

\section{(b) Incidents of Common Socage}

As for various incidents of common socage, incidents of the manorial class which still exist today are the same as (iii) above. However, as well, the following still exist:

(i) Redundant Incidents. Fealty, suit to court, forfeiture to the lord and relief - unlike in the case of copyhold where these have been abolished. Riddall (writing in 2003) noted that: 'These incidents still technically exist but are of no practical importance and are now no more than curiosities' ${ }^{89}$ Riddall also referred to the possibility of other common socage incident still existing, such as an obligation to render a manorial rent; ${ }^{90}$

(ii) Escheat. Two forms of escheat have been long abolished. ${ }^{91}$ However, the common law concept of escheat, as such, has not yet been abolished. Thus, it may continue to apply in very limited circumstances, see 9.

\section{It is asserted that all these common socage tenurial incidents should be abolished.}

\section{(c) Case for Abolition}

It would seem clear, and appropriate, that the incidents in (b)(i) above should be abolished in the case of common socage as they have been in the case of copyhold. They are wholly redundant. Further, that any other incidents of common socage mentioned in (i) should also be abolished. Today, they will be nominal and not of any worth. As for escheat, see 9 and as to the 3rd class of copyhold and common socage incidents, see 13-20.

In conclusion, all incidents of common socage should now be abolished (including escheat, see 9) save for those in the respect of the $3^{\text {rd }}$ class - this, both for common socage tenants and for former copyhold tenants.

probably does not abolish all forms of copyhold escheat. Cf. British General Insurance Co v AG [1945] LJNCCR 113, 125. Also, Law of Property Act 1925, sch 13, pt 2 (15). For the position in older times, see Fisher (in 1794), n 30, ch 9.

${ }^{86}$ Ibid, p 21 (however, the reference should be to 1935). Cf. Harpum, n 32, p 34 lists: (i) quit rents, chief rents and other similar payments; (ii) fines, reliefs, heriots and dues (including fees payable to stewards); (iii) forfeitures other than for alienation in freehold or without licence; (iv) timber rights. See also Law of Property Act 1922, ss 128-9, 138, 140, sch 13, pt 2.

87 'Sporting' referred to killing game, originally, by the lord or a tenant as a necessity for their table. Not as a 'sport' (pastime) as such.

${ }^{88}$ On these manorial rights, see McBain, n 62. Coke, n 2, vol 2, p 700, laid it down that some persons were bound to repair bridges by reason of their tenure of lands or tenements or by reason of prescription. However, p 701 'none can be compelled to make new bridges, where never any were before, but by Act of Parliament.' (italics supplied). See also Williams (in 1880), n 24, pp 363-4. Also, Law of Property Act 1922, sch 12(6) ('construction maintenance cleansing or repair of any dykes, ditches, canals, sea or river walls, piles, bridges, levels, ways and other works required for the protection or general benefit of any land within a manor or for abating nuisances therein...').

${ }^{89}$ Riddall, n 32, p 22.

${ }^{90}$ Ibid, p 22, mentioned an annual rent paid to a lord of the manor for allotments in Blaxhall, Suffolk in 1975 (this is a manorial incident). Whether such are still paid is uncertain. See also Harpum, n 32, p 35, n 85. Also, A Hirst, Blaxhall Council seeks to negotiate with the lord of the manor over Land Dispute (31 July 2014) East Anglian Daily Times (relates to Stone Common, rights said to be acquired by an individual in 1998 when he purchased the title of lord of the manor).

${ }^{91}$ See 9. 


\section{ABOLISHING SARJEANTY}

As a result of the 1660 Act, sarjeanty (grand and petty) was abolished as a tenure but retained as an honorary service. Should grand and petty sarjeanty now be abolished ?As to this:

\section{(a) Grand Sarjeanty}

Sweet (in 1882) stated, as to grand serjeanty, which is a type (that is, a form) of knight service: ${ }^{92}$

Tenure by grand serjeanty is where a man holds his lands or tenements of our sovereign lord the king by such services as he ought to do in his proper person to the king, as to carry the banner of the king, or his lance, or to lead his army, or to be his marshall, or to carry his sword before him in his coronation, or to be his server at his coronation, or his carver, or his butler, or to be one of his chamberlains at the receipt of his exchequer, or to do other like services, etc.

And the cause why this service is called grand serjeanty is for that it is a greater and more worthy service than the service in tenure of escuage. The tenure of grand serjeanty still continues, though it is no longer a tenure by knight's service, the [1660 Act], having converted it into free and common socage, merely preserving the honorary services incident to it. ${ }^{93}$ (italics supplied and wording divided for ease of reference)

This honorary serjeanty - which was (mainly) a military one - is, today, only exercised at the time of the coronation $^{94}$ and it should be limited to such. As noted in a previous article, there are few aspects of it. ${ }^{95}$

\section{(b) Petty Sarjeanty}

Sweet (in 1882) stated as to petty sarjeanty, quoting Littleton (c. 1481):

Tenure by petite serjeanty is where a man holds his land of our sovereign lord the king, to yield to him yearly a bow, or a sword, or a dagger, or a knife, or a lance, or a pair of gloves of mail, or a pair of gilt spurs, or an arrow, or divers [various] arrows, or to yield such other small things belonging to war.' Also, 'And such service is but socage in effect. ${ }^{96}$

This tenure - which was mainly a military one - was abolished by the 1660 Act but the honorary service was retained (although not legally enforceable). However, there is no need for the same and, in practice, such services are never performed now, save on (very) rare ceremonial occasions. ${ }^{97}$ Further, the military purposes of supplying arrows etc - as well as those relating to providing falcons and hounds etc - are long obsolete. This tenure should be abolished. ${ }^{98}$

In conclusion, grand and petty sarjeanty should be abolished - save for coronation services in the case of the former.

\section{ABOLISHING MESNE LORDSHIPS}

As a result of the Statute of Quia Emptores 1290 which abolished subinfeudation, it is not possible to create a mesne (i.e. an intermediate) lordship. It is asserted that all mesne lordships should be abolished (for lords of the manor, see 11). In practice, this should change nothing. As Riddall noted:

\footnotetext{
${ }^{92}$ Coke, n 2, vol 1, s 158 (108a, quoting Littleton) 'all which hold of the king by grand serjanty, hold of the king by knight service; and the king for this shall have ward, marriage and relief; but he shall not have of them escuage, unless they hold of him by escuage.' A fn states 'The tenure by grand serjeanty still continues, though it is so regulated by the [Tenures Abolition Act 1660] as to be made in effect free and common socage, except so far as regards the merely honorary part of grand serjeanty...'. Ibid, s 161 'And note, that a man cannot hold by grand serjeanty, nor by petite serjeanty, but of the king etc.' (i.e. in capite). Grand sarjeanty was not a tenure in socage (unlike petty sarjeanty). Coke, n 2, vol 1, s 117 (86a). See generally, ss 153-8 (105b-108a). As Halsbury Laws, n 62, vol 32, para 95, n 11, notes, grand sarjeanty is a tenurial, not a manorial, service.

${ }^{93}$ Sweet, n 2 (grand serjeanty). For examples see Madox, n 2, pp 242-52. The wording in italics no longer applies.

${ }^{94}$ Coke, n 2, vol 1, s 35 (29b) 'every man that claimed to hold by grand sarjeanty to do any service to the king at his coronation, exhibited his petition to the said duke [of Lancaster, in the time of Richard I (1189-99)] as steward of England, who upon hearing the proofs either allowed or disallowed the same.'

${ }^{95}$ See: (a) McBain, n 62; and (b) GS McBain, Abolishing Obsolete Offices (2012) Coventry LJ, vol 17, no 2, pp 43-50 (listing the 21 claims at the coronation of Elizabeth I in 1953. Ecclesiastical coronation claims are not those of grand sarjeanty as such).

${ }^{96}$ Sweet, n 2 (petty sargeanty). See also Coke, n 2, vol 1, s 159 (108a) \& s 160 (108b).

${ }^{97}$ See McBain, n 62, pp 64-5 (Duke of Cornwall in 1973, some 45 years ago).

${ }^{98}$ See the examples referred to in the article in $n 62$.
} 
all land (except that occupied by the Crown) is in law still held from the Crown, either directly or (most commonly) through mesne lords, whose identity has in the great majority of cases long ceased to be known. $^{99}$ (italics supplied)

For its part, Harpum noted:

all the tenurial incidents (including escheat) ${ }^{100}$ which might in exceptional cases have brought profit to a mesne lord have been abolished, so that there is no inducement for a private person to prove that he is the lord of land. We can, in fact, now describe the theory of tenure, despite the great part that it has played in the history of English law, as a conception of merely academic interest. It no longer restricts the tenant in his free enjoyment of the land. ${ }^{101}$ (italics supplied).

One would agree. Further, it is asserted that it would be (very) difficult for a person today to trace his mesne lordship in an unbroken line from 1290 - more than 700 years ago.

\section{In conclusion, all mesne lordships should be abolished. In practice, there will be no loss. \\ 9. ESCHEAT $^{102}$}

The tenurial incidents referred to in 6-8 above are, today, of no practical consequence and their abolition will effect no practical loss, since they do not arise in practice. The only incident of any consequence is escheat, a common law concept which embraced, in medieval times, escheat for want of heirs and escheat for felony. As to escheat, Wright, in his Introduction to the Law of Tenures (1730), noted that:

When a feud or fee determines for want of heirs, or propter delictum tenentis, the land falls back to the lord, and the land returning to the lord upon such determination of the fee or tenure is called an escheat...the word escheat, as formed from the French word escheoir to happen, and primarily signifying any thing coming accidentally, or by chance, and in such sense comprehending obventions and forfeitures of all kinds...it imports something happening, or returning to the lord upon a determination of tenure only... ${ }^{103}$

For its part, Sweet's Law Dictionary ( $1^{\text {st }}$ edition, 1882) provided:

Escheat takes place when by accident lands fall to the lord of whom they are holden, or to the Crown. It is derived from the feudal rule, that where an estate in fee simple comes to an end, the land reverts to the lord by whose ancestors or predecessors the estate was originally created.

At the present day, seignories in freehold land [i.e. mesne lordships] are of no practical value, and the evidence of them has generally been lost; so that where an escheat takes place the land in almost all cases goes to the Crown as the ultimate lord of all lands in England.

An escheat doth happen in two ways - aut per defectum sanguinis i.e. for default [want] of heirs, as may be imagined, seldom occurs, almost the only case being where a bastard dies intestate without children or other issue. Escheat propter delictum tenentis takes place where a person is outlawed for felony, upon which his blood is corrupted; that is to say, he becomes incapable of holding land, or of inheriting it, and it therefore escheats to the lord. Formerly judgment of death for felony caused an escheat in the same manner as outlawry; but this has recently been abolished, ${ }^{104}$ as has also the rule that

\footnotetext{
${ }^{99}$ Riddall, n 32, p 23. Sweet (writing in 1882), n 2, (seignory) 'Since the Statute of Quia Emptores [1290] no seignory can be created. Owing to the feudal incidents of tenure (fealty etc) having now become obsolete, and to the rent services anciently reserved having become almost valueless, seignories in freehold land are seldom of any practical importance: in most cases indeed they cannot be traced. Consequently almost the only seignories now in existence are those of lords of manors, for a manor does not exist unless there are at least two free tenants, that is, tenants of freehold land forming part of the manor who hold of the lord by a service of some kind. Hence a manor is sometimes said to consist of demesnes and seignories [i.e. land and lordship].'

${ }^{100}$ Escheat has been abolished in the case of want of heirs and for felony (see 9). However, escheat in the case of manors would appear to still be extant in some of the cases referred to Riddall, see text to n 112. See also, re Harpum, n 85.

${ }^{101}$ Harpum, n 32, p 47.

${ }^{102}$ Halsbury Laws, n 62, vol 29, para 145

${ }^{103}$ Wright, n 3, p 117. Coke, n 2, vol 1, s 4 (13a) 'Escheate, eschaeta, is a word of art, and derived from the French word escheat (id est [that is]) cadere, excidere or accidere[to fall, fall down or fall upon], and signifies properly when by accident the lands fall to the lord of whom they are holden, in which case we say that the fee is escheated...an escheat does happen in two ways, aut per defectum sanguinis, i.e for default of heir, aut pur delictum tenentis, i.e. for felony...'. Ibid, s 130 (92a). See also Jessel, n 2, pp 118-9.

${ }^{104}$ Forfeiture Act 1870.
} 
a person could not trace descent to land through an ancestor who has been attainted of treason or felony, so that the land escheated to the lord. ${ }^{105}$

Escheat for want of an heir was abolished by the Administration of Estates Act 1925, s 45 and escheat for felony was abolished by the Forfeiture Act 1870. Escheat for outlawry has also been abolished, with the abolition of the latter in 1938. Escheat should, strictly, be distinguished from forfeiture. However, the two are (often) confused. As it is, forfeiture to the Crown in the case of felony and treason generally (including high treason, for, in effect, breaking the oath of allegiance ${ }^{106}$ was abolished by the Forfeiture Act 1870 . And, forfeiture of copyhold land to the lord of the manor was abolished by the Law of Property Act 1922. Jessel, writing in 1998, noted the following:

The third type of escheat arises under ss $178^{107}$ and $315^{108}$ of the Insolvency Act 1986 when a liquidator of a company or a trustee in bankruptcy of an individual disclaims freehold land which is onerous, that is to say either worthless or a burden. ${ }^{109}$ Examples may be land subject to a heavy rent charge or strict covenants or which was polluted, or a dangerous disused quarry.

Most freehold land is now considered to be held from the Crown (or the royal duchies of Lancaster and Cornwall) and normally they take escheats, but if there is any land held of a subject, or mesne lord, then it will escheat to him. There are four possible cases. The first is former copyhold enfranchised by statute under the Copyhold Acts 1841 to 1894 before $1926^{110}$...The second is where it can be shown

\footnotetext{
${ }^{105}$ Sweet, n 2 (escheat). Also 'Etymology- Norman French, eschete, from escheoir, to fall to (in the sense of a wind-fall); Latin, cadere.'For escheat, see also Chambers, n 8, pp 192-201. These only proper forms of escheat were for wants of heirs and for felony, see Fisher (in 1794), n 30, pp 76-7. Halsbury Laws, n 62, vol 29, para 147 summarises the whole law of escheat in just one paragraph. Indeed, it states 'Escheat is the capacity of the chief lord to resume land granted to him or a predecessor in title on determination of the estate granted. It may now arise on disclaimer. This may be by a trustee in bankruptcy or a liquidator [i.e. Insolvency Act 1986, ss 178 \& 315] or the Treasury solicitor [i.e. Companies Act 2006, s 2013]...'.

${ }^{106}$ As indicated in $\mathrm{n} 51$, the oath of allegiance is not the same as the oath of homage and the oath of fealty. It is general and applies to all British subjects (as well as some others) regardless of any tenure (land holding) - including manorial land. This common obligation of allegiance principally derives from William I (1066-87), in 1085, requiring all his tenants in capite to swear allegiance to him in person. See Hearn, n 25, p 327 'And there came before him his barons and all landholders who were of any account, of whatsoever fief they were; and they were all made his men, and swore to him fidelity against all men.' See also Williams, n 24, p 293 (forfeiture for outlawry has also been abolished, in 1938).

${ }^{107} \mathrm{~s} 178$ (power to disclaim onerous property) '(1) This and the next two sections apply to a company that is being wound up in England and Wales. (2) Subject as follows, the liquidator may, by the giving of the prescribed notice, disclaim any onerous property and may do so notwithstanding that he has taken possession of it, endeavoured to sell it, or otherwise exercised rights of ownership in relation to it. (3) The following is onerous property for the purposes of this section - (a) any unprofitable contract, and (b) any other property of the company which is unsaleable or not readily saleable or is such that it may give rise to a liability to pay money or perform any other onerous act. (4) A disclaimer under this section - (a) operates so as to determine, as from the date of the disclaimer, the rights, interests and liabilities of the company in or in respect of the property disclaimed; but (b) does not, except so far as is necessary for the purpose of releasing the company from any liability, affect the rights or liabilities of any other person. (5) A notice of disclaimer shall not be given under this section in respect of any property if - (a) a person interested in the property has applied in writing to the liquidator or one of his predecessors as liquidator requiring the liquidator or that predecessor to decide whether he will disclaim or not, and (b) the period of 28 days beginning with the day on which that application was made, or such longer period as the court may allow, has expired without a notice of disclaimer having been given under this section in respect of that property. (6) Any person sustaining loss or damage in consequence of the operation of a disclaimer under this section is deemed a creditor of the company to the extent of the loss or damage and accordingly may prove for the loss or damage in the winding up.'

${ }^{108}$ s 315 (disclaimer (general power)). (1) Subject as follows, the trustee may, by the giving of the prescribed notice, disclaim any onerous property and may do so notwithstanding that he has taken possession of it, endeavoured to sell it or otherwise exercised rights of ownership in relation to it. (2) The following is onerous property for the purposes of this section, that is to say - (a) any unprofitable contract, and (b) any other property comprised in the bankrupt's estate which is unsaleable or not readily saleable, or is such that it may give rise to a liability to pay money or perform any other onerous act. (3) A disclaimer under this section - (a) operates so as to determine, as from the date of the disclaimer, the rights, interests and liabilities of the bankrupt and his estate in or in respect of the property disclaimed, and (b) discharges the trustee from all personal liability in respect of that property as from the commencement of his trusteeship, but does not, except so far as is necessary for the purpose of releasing the bankrupt, the bankrupt's estate and the trustee from any liability, affect the rights or liabilities of any other person. (4) A notice of disclaimer shall not be given under this section in respect of any property that has been claimed for the estate under section 307 (after-acquired property) or 308 (personal property of bankrupt exceeding reasonable replacement value) or 308A, except with the leave of the court. (5) Any person sustaining loss or damage in consequence of the operation of a disclaimer under this section is deemed to be a creditor of the bankrupt to the extent of the loss or damage and accordingly may prove for the loss or damage as a bankruptcy debt.'

${ }^{109}$ Jessel, n 2, p 120 referred to Scmilla Properties Ltd v Gesso Properties BVI Ltd [1995] ECGS 52. Also, to Hindcastle Ltd v Barbara Attenborough Associates [1996] 1 AE 737. See also Halsbury Laws, n 62, vol 29, para 145.

${ }^{110}$ However, Jessel noted, n 2, p 123 'in the case of copyhold land, para (1)(c) of sch 12 to the Law of Property Act 1922, provides that all former enfranchised land under the Act shall henceforth be held free of any escheat to the lord. It can of course escheat to the Crown.'
} 
that the land was originally sold out of a sub-manor...The third is land subject to a rent of assize... ${ }^{111}$

The fourth is former glebe land... ${ }^{112}$

However, this is not (strictly) accurate. A disclaimer of land is statutory. It is not, therefore, common law escheat which existed long before companies and bankruptcy. Further, the medieval concept of escheat did not cover disclaimer by the tenant - whether of his tenurial land or the tenurial service obligation. Thus, ss 178 and 315 are better treated as statutory (not common law) examples of bona vacantia in any case ${ }^{113}$ and statutory provision should state this (see Appendix A), if escheat is abolished. As to the latter cases mentioned by Jessel (land held of a subject or a mesne lord), such cases are now (very) rare and comprise anomalies not worth retaining. Also, if the tenurial system is abolished, it is appropriate that the common law of escheat should be abolished - the same to include escheat to the duchies of Lancaster and Cornwall which comprise franchises of the Crown's prerogative (right) to escheat. If escheat is abolished (and ss 178 and 315 treated as examples of bona vacantia) provision should also be made $^{114}$ for cases where land is:

(a) without an owner; ${ }^{115}$ or

(b) disclaimed by its owner generally (cf. when onerous, see above). ${ }^{116}$

These should be treated not as escheat but as a statutory form of bona vacantia to the Crown only (and not to any duchy). ${ }^{117}$

\section{In conclusion, escheat should be abolished.}

\section{NORMAN TENURIAL SYSTEM - CONCLUSION}

The vestiges of the Norman tenurial (landholding) system should be abolished. Abolition will have no practical effect (or loss). Such will enable all land in England and Wales to be held directly by the freeholder (including the Crown) and not directly, or indirectly, of the Crown.

Abolition of the tenurial system could be achieved without abolition of the manorial system. Also, without the abolition of certain franchises of the Crown prerogative which were (often) given to knights and to lords of the manor. However, to avoid uncertainty - and because the manorial system is also, effectively, redundant - it is asserted that a Land Reform Act should also abolish both of these. This matter is now considered.

\section{THE MANOR}

It has been previously noted (see 1) that the manor was not part of the Norman tenurial system. ${ }^{118}$ That is, a manor, as such, was not held of the Crown in return for the performance of a service obligation to the same. Not least, since (probably) the concept of the manor pre-dates the Norman Conquest $1066 .{ }^{119}$ However, postConquest, the lord of the manor was (often) a knight and, to an extent, his 'mini-sovereignty' was reflected within the manor in terms of the manorial incidents (i.e. rights and obligations) which were owed to him (and by

\footnotetext{
${ }^{111}$ The rent was a fixed rent, payable in lieu of the performance of the service. See also Sweet, n 2 (rent) 'Before the Statute Quia Emptores [1290], a person could convey land in fee simple to be held of him and his heirs, and reserving a rent service from the grantee. Some instances of rents thus created still exist either under the name of fee farm rents or of quit rents, so called because in consideration of their payment the tenants are quit or discharged of all other services. Such rents are now found almost only in manors, being frequently due both by the freeholders and the copyholders: they are sometimes called customary rents, being due by custom; or rents of assize, from being fixed in amount; and those of the freeholders are frequently called chief rents.' (italics supplied)

${ }^{112}$ Jessel, n 2, p 120. Sweet, $\mathrm{n} 2$ (glebe) 'Glebe in ecclesiastical law is a portion of land attached to a benefice as part of its endowment.'

${ }^{113}$ Bona vacantia has always been rather an elastic category. Originally, it only applied to personal property. However, it was extended to freeholds. Also, to the equity of redemption of freeholds. Further, it used to cover treasure trove, estrays and royal fish. However, they are no longer classed as such. See Halsbury Laws, n 62, vol 29, para 149, n 1.

${ }^{114}$ It should be made because, in the case of (a), under the Norman tenurial system, the Crown owns all land (whether directly or indirectly) Thus, if this system is abolished clarity needs to be given as to land which no one else claims. Also, it would seem apposite today to includethe case of (b), where the owner disclaims land, even if not onerous.

${ }^{115}$ Because not all land is registered and because land itself can diminish or grow (the result of the actions of the ocean and rivers) it is possible for the ownership of land to be unknown. If so, it would seem appropriate for the Crown to acquire ownership of the same as bona vacantia.

${ }^{116}$ Generally, if you own land you cannot disclaim it. However, it would seem appropriate for the Crown to have the option to take ownership where a person deliberately abandons it (cf. where it is onerous property, see ss 178 and 315 referred to in the text) and the Crown is prepared to accept title to the same.

${ }^{117}$ Since the duchies no longer retain revenue arising from bona vacantia (they give it to charity) any right of the same to bona vacantia should be abolished, to help simplify the law.

${ }^{118}$ Jessel, n 2, p 357 'manors are not, as such, part of the feudal system or necessarily held in fee.' For manors generally see Halsbury Laws, n 62, vol 32, para 95 et seq.

${ }^{119}$ E Howlett (the Manor and Manor Law), in W Andrews, Legal Lore (1896), p 83, put it thus 'The name 'manor' is of Norman origin, but the estate to which it was given existed, in its essential character, long before the [Norman] Conquest.'
} 
him) in respect of his free tenants and villeins (later, copyholders). As for his slaves, they had 'died out' (probably) by the $13^{\text {th }}$ century becoming either free tenants or villeins. Further, they were mere chattels anyway, having no rights. Sweet's Law Dictionary noted in 1882 that:

almost the only seignories [i.e lordships] in existence are those of lords of manors, for a manor does not exist unless there are at least two free tenants, that is tenants of freehold land forming part of the manor who hold of the lord by a service of some kind. Hence a manor is sometimes said to consist of demesnes [lands] ${ }^{120}$ and seignories. ${ }^{121}$

In the case of a manor, various manorial incidents still exist (although some are now theoretical or rarely availed of), see 12-20. Further, the title, 'lord of the manor' can be held separate from any land holding. That is, in gross. As a result, from the 1950's, there was a tendency of persons with aspirations to seek to become 'lord of the manor ${ }^{122}$ and to acquire the title, without being interested in any manorial incidents that were financially of worth which, in any case - as early as the 1950's - had become very meagre. ${ }^{123}$ Should the legal concept of the manor be abolished? When considering this, there would seem to be 3 possibilities:

1. abolish (i) the legal concept of a manor; (ii) the title 'lord of the manor'; and (iii) all (or some) manorial incidents; or

2. abolish (i) and (iii),but not (ii) (i.e. retain the title of lord of the manor); or

3. abolish (i) and (ii) and de-link manorial incidents from being such.

As will be seen, it is asserted that no 3 would seem the best option. Not least, since few (if any) manors still exist, since a manor - in strict legal terms - must have existed pre-1290 (i.e. before the Statute of Quia Emptores 1290). The history of the manor will now be considered.

\section{(a) Introduction}

It is likely that - in Roman Britain - a manor (manerium) ${ }^{124}$ existed as a large form of estate (land holding). ${ }^{125}$ One in which the owner (likely, a person of considerable status) farmed his land using slaves he owned as well

${ }^{120}$ Chambers, n 8, p 48 'Demesne, according to Lord Coke's etymology, is derived from de main, or manual occupation: but as it is in latin dominicium, it may much more probably be derived from dominus.' One would suggest that the English word 'domain' (land owned by a person) reflects accurately the word 'demesne'. See also Oxford English Dictionary (demesne). Sweet, n 2 (demesne) 'In its primary sense 'demesne' signifies 'own' or that which is a man's private property...Demesne also applied to those parts of a manor which were in the possession or occupation of a freehold tenant, or of his lessees for years, as opposed to those which others held of him for an estate of freehold...Demesne was also applied to those parts of a manor which were in the occupation of the lord, or of his villeins, or tenants for years, being cultivated 'for the necessary sustentation, maintenance, and supportation of the lordand his household', as opposed to that part of the manor which had been granted out to free tenants in consideration of services; hence, a manor is said to be held in dominico and in servitio, or to consist of demesnes and services. At the present day the demesne lands of a manor consist (1) of the lord's demesnes, or that part which is in the actual occupation of the lord, (2) of the copyholders' demesnes, or the part held by copyhold tenants, and (3) of the waste land of the manor.' See also Madox, n 2, p 65. For the division of demesnes into 'inlands' (where the lord kept the land on the manor for his own immediate use and enjoyment) and 'uplands' (also called, 'outlands', 'because those lands were in the occupation and manurance of certain tenants, who, in consideration of the profits arising from those lands, were bound to perform unto their lords certain duties and services'), see Fisher, n 30, pp 4-5.

${ }^{121}$ Sweet, n 2, (seignory). See also n 58.

${ }^{122}$ In the 1980's, in particular, it became fashionable to buy the title of lord of the manor (footballers and tennis stars seemed to be especially attracted to it). Jessel, n 2, p 46 'In the 1980s many people who had spare money and were looking for something unusual to spend it on found that they could purchase the title of lord of some obscure manor for a few thousand pounds. The most famous lordship to be sold was Henley in Arden (which includes Stratford on Avon) which changed hands in 1988 for £87,000. Even an obscure manor with no rights could, at the height of the 1980 s boom, fetch $£ 10,000$. This was a pure status commodity and the market collapsed when the economy declined, but it left many people wondering about what manors were and what rights might be attached to them. More recently sales have revived. The manor of Wimbeldon was sold at auction in May 1996 for $£ 171,000$ as a result, it is said, of bidding between rival tennis stars.'

${ }^{123}$ This point is, often overlooked, when considering things such as class 3 sporting or mineral rights. However, for example, a sale of 56 lordships of manors in the counties of Essex, Suffolk and Norfolk in 1954 shows, in the sale details, that manorial rights to the lord had become few and were not emphasised. See Catalogue for the Sale of the Beaumont Collection of Manors at auction on $3^{\text {rd }}$ November 1954 and a further sale by private treaty. For example, lot 1 (sale of the manor of Layer Breton, p 9) referred as income to: (a) two wayleave agreements with the Eastern Electricity Board (rent at $£ 1,16 \mathrm{~s} \mathrm{p.a.);} \mathrm{(b)} \mathrm{rent} \mathrm{for} \mathrm{grazing} \mathrm{on} \mathrm{the} \mathrm{heath} \mathrm{(} £ 5$ p.a.in the past, but not now let); (c) payment from time to time of $£ 7$ by a circus to use the heath, after consulation with the police etc; (d) sporting rights 'over the heath have from time to time been let' but not presently. In the case of lot 9 (sale of the manor of Martells Hall, p 20) the enfranchisement rent charges out of former copyhold land, included in the lot comprised two at $£ 1,6 \mathrm{~s}$ and at $13 \mathrm{~s}$ p.a. respectively. All very meagre.

${ }^{124}$ Sweet, n 2 (manor) 'Etymology and history. Manor is derived from the Norman-French, manoir, maners (latin, manerium, from manere, to remain or dwell), a dwelling or habitation, originally applied to the mansion of the lord. It is now generally supposed that manors were not a creation of the Norman Conquest, but an adaptation to the Norman rules of tenure of the institutions known as village communities which existed among the Saxons.'

${ }^{125}$ Jessel, n 2, pp 15-6, noted that, in classical latin, dominus tended to mean 'master' or 'owner', whereas in medieval latin, it was translated as 'lord'. Thus, lord of the manor (estate). Also, that the dominus of the fundus (estate) that surrounded the villa (main house), after many 
as the service of agricultural tenants who were not such (i.e. who were free, including freed slaves). After the Romans departed from Britain in AD 410, it is also likely that the manor continued to exist - to some extent - in Anglo-Saxon times ${ }^{126}$ (although it has been a matter of conjecture as to whether land in England at that time was owned freely (allodially) and without any 'lord' in such a time ${ }^{127}$ - that is, whether there was a feudal system of tenure).Thus, the Anglo-Saxon manor would not have been unknown to post-Conquest England. ${ }^{128}$

- Manor as a Legal Concept. What William I (1066-87) did, however, was to define a manor as a legal concept and to integrate it into the Norman tenurial system. Thus, the lord of the manor (a mesne lord ${ }^{129}$ was the person who owned a manor which - in Norman times - would have been a large landed estate. Further, such would have comprised 'demesne land' (that is, land which he owned and cultivated himself) as well as land which he owned but which was occupied by socage tenants(free holders) and villeins (peasants). Also, 'manorial waste' (that is, land which the lord of the manor owned but which he did not cultivate), ${ }^{130}$

- $\quad$ Those who farmed the Manor Land. The lord of the manor would have had villeins and, sometimes, slaves ${ }^{131}$ who helped cultivate his land - the former holding any house and land at will and the latter being treated as chattels. Also, the lord of the manor would have had agricultural labourers who held their house and land from him as free holders (i.e. by way of common socage);

- Manorial Courts. If the lord of the manor had socage tenants (free holders) he would have a manorial court (a court baron) to deal with any land disputes (in the case where the Crown was lord of the manor in the time of Edward the Confessor (1042-66) or William I (1066-87), the court for the freehold tenants was called a court of ancient demesne). ${ }^{132}$ In the case of villeins, the court was called a court customary to deal with such disputes;

centuries, became the 'lord' of the estate. One would agree and that, at base, 'lord ofthe manor' was, simply, a reference to the owner of a large amount of land (estate), the Anglo-Saxon translation of 'estate' being 'land'. Under Roman law, land holding (tenure) was categorised into: (i) fiscus (state land); (ii) fundus (private land); and (iii) ager (private fields, owned by a small holder).

${ }^{126}$ One would surmise that the Roman categorisations of fiscus and fundus (see fn above) disappeared. However, that the concept of an estate (now called land, inAnglo-Saxon) continued, together with reference to the owner of the same as dominus (lord, master, owner). The extent to which slaves were used in Anglo-Saxon times to farm land is uncertain. However, as with the Roman fiscus, this would seem (very) likely.

${ }^{127}$ The extent to which land was privately owned by small farmers who owned their land outright (i.e. the land was allodial and not tenurial) is uncertain. However, given all the turmoil, it would seem likely that much of England was owned by the king and manor landowners (ealdormen, elder men) who owed allegiance to the king, as well as by the church, and that this continued post king Alfred (AD 886-99). King Athelstan (925-39) issued a law (doom, ordinance) which required all free men to have a lord to whom they were accountable. This, likely, help precipitate a system of power (and land owning, tenure) being concentrated in a few persons, whose land was, then, worked by slaves and peasants (tied to the land). Also, by free tenants (socmen) who owned their land but it was subject to their allegiance to a lord. Thus, there was an increasing tendency to a feudal system. See also FL Attenborough (ed), The Laws of the Earliest English Kings (1963), p 129 'With regard to lordless men from whom no [legal] satisfaction can be obtained, we have declared that their relatives shall be commanded to settle them in a fixed residence where they will become amendable to publiclaw, and find them a lord at a public meeting.' See also Jessel, n 2, pp 19-25.

${ }^{128}$ Cf. Jessel, n 2, pp 26-7 'The manor itself was not known in England before 1066' and that, after 1066, 'All of England was divided into in manors. The few cases where land was not in any manor are specifically noted [in the Domesday Book].' However, one would suggest that the first sentence overstates the position. The manor as a factual description of a large estate (land) with an owner was known. All William I did was to incorporate it into the feudal system of land-holding, ending any allodial land at the same time and replacing, in most instances, the major Anglo-Saxon landowners (mainly, thanes and ealdormen) with his knights (barons). This also accords better with the later statement of Jessel, p 28 'The Norman and Flemish and Breton followers of William [I] saw themselves as taking over an existing system, not imposing a new one.'

${ }^{129}$ That is, the lord of the manor was intermediate between the tenant and the Crown save where the Crown was, itself, lord of the manor which occurred in the case of estates in ancient demesne.

${ }^{130}$ After the Black Death in 1351, lords of the manor tended to lease out their demesne land, see McBain, n 1, p 38. This initiated the process of the decline of the manor.

${ }^{131}$ At the time of the Norman Conquest, there were slaves. However, by the $13^{\text {th }}$ century, they had died out as a class. See also the text to $n$ 70.

${ }^{132}$ Land held by King Edward the Confessor (1042-66) and William I (1066-87) was called land in ancient demesne. And, there was a distinct court, a court of ancient desmene, to deal with disputes relating to the land between the Crown and the tenants. Harpum, n $32, \mathrm{p} 47$ 'Ancient demesne land was land held by freehold tenants in any manor that had belonged to the Crown in the time of Edward the Confessor or William the Conqueror. The tenants in ancient demesne were subject to certain restraints and entitled to certain immunities.' Sweet, $\mathrm{n} 2$ (ancient demesne) 'a freehold tenure confined to socage lands held of manors which belonged to the Crown in the reigns of Edward the Confessor and William I and are described in Domesday Book as Crown lands (terrae regis or terrae regis Edwardi). The tenants are freeholders, and formerly had exceptional privileges, the chief of which was the right to sue and be sued on questions affecting their lands in a manorial court called the Court of Ancient Demesne...'. See also Chambers, n 8, pp 214-5 and Jessel, n 2, ch 24. 
- Manorial Criminal Court - Court Leet. Also, by way of a franchise of the Crown prerogative, lords of the manor had the right to hold a court leet. That is, a court to deal with minor infractions of the criminal law within their jurisdiction. ${ }^{133}$ Such a court may have existed in Anglo-Saxon times. However, from the time of Henry I (1100-35), at least, it would have been treated as a franchise since the Crown from this time was asserting that it had jurisdiction over all crimes (pleas of the Crown), save where it franchised the same (for example, to a court leet). ${ }^{134}$

\section{(b) Manors \& Reputed Manors - The Difference}

The Statute of Quia Emptores 1290 prevented the creation of any manor after 1290 (even by the Crown). Indeed, any manor existing in the period 1189-1290 would only have existed as a sub-manor and not as a manor as such. ${ }^{135}$ As a result, the English courts held that a manor could only exist, legally, if it had:

- been created prior to 1290 ; and

- it had, at least, two tenants holding in common socage on the land (i.e. two free tenants or freeholders) ${ }^{136}$ so that a court baron could be held. ${ }^{137}$

Thus, in Glover v Lane (1789), ${ }^{138}$ Kenyon CJ stated:

to constitute a manor it is necessary not only that there should be two freeholders within the manor, but two freeholders holding of the manor subject to escheats. ${ }^{139}$

Further, as Coke noted in his Institutes of the Laws of England (1628), the Crown cannot create new manors. ${ }^{140}$ In conclusion, Jessel observed (in 1998):

The manor court [i.e. the court baron, the court of the lord] was the essential feature of the manor: a necessary adjunct. It was inseparable from the lordship which could not exist without it. ${ }^{141}$

\footnotetext{
${ }^{133}$ Sweet (writing in 1882), n 2 (court leet) 'The lords of a great number of manors have the privilege of holding a court leet, which, so far as it is useful in the present day, is held for the purpose of presenting small offences in the nature of a common nuisance, which require immediate attention and redress. It is a court of record; the steward of the manor is the judge and the jury is formed from the inhabitants. Originally it was a court of criminal jurisdiction over the tenants and the resiants (or persons resident within the manor) in all matters in which the sheriff's tourn had jurisdiction, from which court it is said to be derived; it also had the 'view of frank pledge', but these portions of jurisdiction are quite obsolete.'

${ }^{134}$ LJ Downer (ed), Leges Henrici Primi (Clarendon Press, 1972). This cites the (so-called) Laws of Henry I (1100-35), including provision on the royal jurisdiction, where breaches of the criminal law were termed breaches of the king's peace. See, p 109. See generally, as to breach of the peace, GS McBain, Modernising the Law: Breaches of the Peace and Justices of the Peace (2015) Journal of Politics and Law, vol 8, no 3, pp 170-1.

${ }^{135}$ See McBain, n 62, p 43.

${ }^{136}$ Jessel, n 2, p 70 'every manor had to have at least two dependent freeholders.' Coke, n 2, vol 1, s 73 (58a) 'The court baron must be holden [held] on some part of that which is within the manor, for if it be holden out of the manor it is void...this court is of two natures. The first is by the common law, and is called a court baron, as some have said, for that it is the freeholders or freemans court (for baron in one sense signify[ies] freemen), and of that court the freeholders being suitors be judges, and this may be kept from three weeks to three weeks. The second is the customary court, and that does concern copyholders, and therein the lord or his steward is the judge. Now there can be no court baron without freeholders, so there cannot be this kind of customary court without copyholders or customary holders. And as there may be a court baron of freeholders only without copyholders, and then is the steward the register, so there may be a customary court of copyholders only without freeholders, and then is the lord or his steward the judge. And when the court baron is of this double nature, the court roll contains as well matters appertaining to the customary court, as to the court baron. And for as much as the title or estate of the copyholder is entered into the roll whereof the steward delivers him a copy, thereof he is called the copyholder.'

${ }^{137}$ Sweet (writing in 1882), n 2 (court baron) 'A court baron, in the original sense of the word, is a court in which the free tenants or freeholders of the manor are the judges, and the steward of the manor is the registrar. In it all suits concerning lands held of the manor might be, and in early times not unfrequently were, determined, but their jurisdiction in real terms has been practically abolished, and now such courts are rarely held...'. The court baron should be distinguished from the copyholders court (the court customary), although it is (confusingly) also referred to, sometimes, as the customary court baron.

${ }^{138} 3$ TR 445 at 447. HW Peek, Six Essays on Commons Preservation, containing a legal and historical examination of Manorial Rights and Customs (1867), p 353 'To constitute a manor it is necessary not only that there should be two freeholders within the manor, but two freeholders holding of the manor, subject to escheats...'. Peek continued 'But in order to prove his claim to two such freeholders, the lord [of the manor] must show that their [his] ancestors or predecessors in title were tenants of the manor at a date anterior to [1290]...The difficulty of tracing an unbroken title through so long a period is evidently sufficient to make the cases in which such freeholders can be claimed by a manor extremely rare...'(italics supplied). See also McBain, n 1, p 23, n 147.

${ }^{139}$ See also Halsbury Laws, n 62, vol 32, para 99.

${ }^{140}$ Coke, n 2, s 31 'the king himself cannot create a perfect manor at this day; for such things as receive their perfection by the continuance of time come not within the compass of a king's prerogative...'. Halsbury Laws, n 62, vol 32, para 98 'A manor cannot be created today except by Act of Parliament...'. Fisher, n 30, p 3 'a manor certainly cannot begin this day.'

${ }^{141}$ Jessel, n 2, p 216.
} 
As a result, the large majority of manors today are not, legally, manors. They are 'reputed' (that is, 'alleged' or 'pretended') manors (i.e. a seignory (lordship) in gross), ${ }^{142}$ in which no one has legally challenged the title to the same. Thus, many a 'manor', 'manor farm' or 'manor house' is not such, legally. Instead, this is, merely, an affectation. Many of these manors will have sprung up in Tudor and Jacobean times when rich merchants and others thought to acquire status by buying land and, then, asserting that they were the lord of a manor. And, there was no one around with sufficient presumption to legally challenge them. Sweet (in 1882) stated:

Properly speaking a manor is a district of land of which the freehold is vested in a person called the lord of the manor, of whom two or more persons, called freeholders of the manor, hold other land in respect of which they owe him certain free services, rents or other duties. Hence every manor must be at least as old as the Statute of Quia Emptores [1290]; indeed, immemorial existence is essential to a manor.

The land which is vested in the lord is called the demesnes and comprises (1) the land of which the lord is seised, and which may be wholly in his own occupation or in that of his lessees for years, but in most manors [this] is to a great extent in the occupation of the copyhold and customary tenants of the manor; and (2) the waste lands of the manor, usually subject to the tenants' customary rights of common.

A court baron for the freeholders, and a customary court for the copyholders (if any), are necessary incidents to every manor, and the principal manor in a parish usually has an advowson appendant to the demesnes. There are also either annexed or appurtenant to the manor a variety of franchises exercisable by the lord, such as a right to have a court leet, the right to waifs and strays, treasure trove, wreck, the liberties [franchise] of holding fairs and markets, of taking tolls and the like.

Accordingly, a manor proper is shortly defined as consisting of demesne lands, jurisdiction in a court baron, and services of free tenants in fee, who are liable to escheat and owe attendance at the court; or more shortly still as consisting of demesnes and services.

If the number of free tenants is reduced below two, the court baron cannot be held, and the manor ceases to exist, but may survive as a manor by reputation for the purpose of making title to franchises or for holding copyholders' courts. If all the demesnes are alienated, the manor is extinguished, and becomes merely a 'lordship in gross', while a temporary severance of all the demesnes, as by a lease for years, causes a suspension of the manor. ${ }^{143}$

\section{In conclusion, most 'manors' today are not legally such. They are presumed (alleged) manors.}

\section{(c) Abolishing title of 'Lord of the Manor'}

Given that the title of 'lord of the manor' is (often) a mis-assertion of the true legal position (whether the title is held in gross or the titleholder, also, owns some manorial land) and that this causes confusion, it would seem appropriate - if the legal concept of the manor is abolished - to, also, abolish the title 'lord of the manor' and not leave such as a title in gross, one which can be bought and sold. Such would be to invite confusion and such a title, anyway, is not an honour as such. ${ }^{144}$ That is, the title 'lord of the manor' does not descend from - and is not granted by - the Crown by means of letters patent or otherwise.

\section{In conclusion, it is asserted that the title 'lord of the manor' should be abolished if the legal concept of the manor is abolished.}

\section{(d) Abolishing Manorial Courts ${ }^{145}$}

Obviously, if the legal concept of a 'manor' is abolished, then, all manorial courts should be abolished. However, it would be possible to abolish all manorial courts (including courts baron) and, yet, preserve the legal

\footnotetext{
${ }^{142}$ Ibid, p 218 'As the suitors [to a court baron] were an integral part [of a manor], there had to be at least two of them in the manor, one to bring his case and the other to act as judge. Thus if in any manor there were less than two freeholders of the manor, it could not have a properly constituted court baron and became a reputed manor.' See also Baxendale v Instow Parish Council [1982] 1 Ch 14, 27 (Megarry VC) 'If there ceased to be at least two free tenants of a manor, the manor became a 'reputed'; for the freeholders were the judges of the court baron, and at least two were needed so that an only freeholder would not be his own judge....'

${ }^{143}$ Sweet, n 2 (manor).

${ }^{144}$ Jessel, n 2, p 368 'lord of the manor is not a title in any of the senses given in this chapter [he was considering titles such as princes, marquesses etc]. It refers only to the person who owns the lordship. He is not entitled to be called 'lord' or ' $m y$ lord' or to sit in the House of Lords; he is not necessarily a gentlemen or indeed a human at all since a lordship can be owned by a company and many are owned by the church and by Oxford and Cambridge colleges... The lord of the manor is not, as such, a lord, although in the past most were squires and many lords who own estates also are lords of manors.' Halsbury Laws, n 62, vol 32, para 96 'The owner of a manor is called the lord of the manor, though the lordship is not a title of dignity and confers no social rank.'

${ }^{145}$ Ibid, ch 13. See also Halsbury Laws, n 62, vol 32, para 99
} 
concept of a manor. As it is, the vast majority of manorial courts - that is, courts baron, courts of ancient demesne and courts customary - were, in practice, long obsolete prior to the Administration of Justice Act 1977('AJA 1977'). Indeed, the Judicial Statistics of 1859 indicated that only 5 courts baron appeared to be extant (a court baron being necessary for the existence of a genuine manor, see (b) above). The same applies to courts leet which are, strictly, franchisal courts, as opposed to being manorial courts as such (they can exist other than on manors). As it is, the AJA 1977, s 23, which is still extant, preserved the operation of two courts the estray court of the lordship of Denbigh and the court leet for the manor of Laxton ${ }^{146}$ - neither of which are courts baron - and it enabled 32 other courts (not all of them courts baron) to continue to conduct customary business (but not legal proceedings). It provides as follows:

(1) The following courts, namely... any court of a description specified in [sch 4, pt 1] ${ }^{147}$ except -

(i) the estray court for the lordship of Denbigh, and

(ii) the court leet for the Manor of Laxton, ${ }^{148}$ and

(iii) the courts specified in Part II of that Schedule,

being the courts which appear to the Lord Chancellor to have, but not to exercise, jurisdiction to hear and determine legal proceedings, shall cease to have any jurisdiction to hear and determine legal proceedings; but any such court may continue to sit and transact such other business, if any, as was customary for it immediately before the coming into force of this section, and in the case of the courts specified in [sch 4, pt 3 which refers to some 32 courts] the business that is to be treated as having been customary shall (apart from business relating to the appointment of officers of the court) be the business specified in relation to that court in column 2 of that Part.

(2) The descriptions of courts in Part I of Schedule 4 to this Act include courts held for manors of which the Queen or the Duke of Cornwall is the lord.

Thus, all these 32 courts (which included manorial courts) no longer have, since 1977, jurisdiction to determine legal matters. However, they still can 'transact such other business...as was customary for it' prior to the Act. By reference to the 32 courts specified in sch 4, pt 3, what is 'customary business' includes:

(a) perambulating boundaries;

(b) receiving an 'address';

(c) proclaiming a charter;

(d) 'observing' a mid-summer fair. ${ }^{149}$

It should be noted, though, that none of these are legal requirements anyway. Also, since 1977, a major change has occurred - such that these courts cannot (it seems) have any legal vitality. This is due to the European Convention on Human Rights (ECHR) which has been incorporated into English domestic law by the Human Rights Act 1998, article 6 of which provides (in part):

In the determination of his civil rights and obligations or of any criminal charge against him, everyone is entitled to a fair trial and public hearing within a reasonable period of time by an independent and impartial tribunal established by law. (italics supplied)

However, none of the persons in the courts mentioned in the AJA 1977, s 23 - and, especially, the 32 courts referred to (as well as the estray court of Denbigh and the court leet of Laxton) - are legally qualified. Thus, they lack the training and expertise required of legally qualified, impartial, judges. Further, they cannot be said to be 'independent' since they are manorial tenants and, thus, intimately concerned in any civil (or criminal) land matter affecting it. ${ }^{150}$ Such, also, applies to the hundred court which is only a larger court baron. ${ }^{151}$

\footnotetext{
${ }^{146}$ The first deals with stray sheep once a year, see McBain, $\mathrm{n} 62, \mathrm{p} 48, \mathrm{n} 43$. The second sits at Laxton manor which operates the last open field system in England and Wales. See McBain, n 1, p 51.

${ }^{147}$ Sch 4 (schedule of curtailment of jurisdiction of certain ancient courts), part 1 (description of courts) referred to: (a) courts baron; (b) courts leet; (c) customary courts of the manor; (d) courts of pie poudre; (e) courts of the staple; (f) courts of the clerks of the markets (or clerk of the market); (g) hundred courts; (h) law days; (i) views of frankpledge; (j) common law (or sheriffs') county courts as known before the passing of the County Courts Act 1846.

${ }^{148}$ Reference is made to a court leet and not to a court baron. Thus, Laxton is now (probably) a reputed manor, in reality.

${ }^{149}$ Jussel, n 2, p 226 ' Customary' here probably means according to legal custom...'.

${ }^{150}$ Halsbury Laws, n 62, vol 32, para 99 fails to mention article 6.

${ }^{151}$ Sweet, $\mathrm{n} 2$ (hundred court), writing in 1882 'Hundred Court is only a larger court baron, being held for all the inhabitants of a particular hundred instead of a manor. Hundred courts are now seldom held.' Today, none are held.
} 
- Courts of Ancient Demesne. The AJA 1977, sch 4, pt 1 did not specifically refer to courts of ancient demesne. ${ }^{152}$ These also should be abolished, being long obsolete.

Given that courts baron are necessary for the existence of a manor, if they are abolished, then, so too are manors (cf. reputed manors). Thus, it is asserted that all courts referred to in the AJA 1977 s 23 (including the 32 referred to in sch 4, pt 3) should be abolished - whether or not the legal concept of a 'manor' is abolished since they are, now, wholly redundant.

In conclusion, all the courts referred to in the AJA 1977, s 23 and sch 4 (pts 1-3) should be abolished whether, or not, the legal concept of a manor is abolished. ${ }^{153}$

\section{(e) Conclusion}

It is asserted that the legal concept of a 'manor' should be abolished. So too, the title 'lord of the manor' and all manorial courts. As noted previously (see (b)), it would be possible to abolish the former while preserving the title. And, it would be possible to abolish all manorial courts, while preserving the legal concept of a manor. However, all 3 are intimately connected and, thus, all 3 should go at one and the same time since, today, the concept of a 'manor' is not legally required and most legal matters relating to the manor are obsolete ${ }^{154}$ However, if the legal concept of a 'manor' is abolished, it is necessary to consider the legal consequences of such an action. First, more minor matters will be considered in 12. Then, in 13-20, the class 3 incidents (rights and obligations) mentioned in 6(a)(iii) are discussed.

In conclusion, the legal concept of a 'manor' should be abolished - as well as the title 'lord of the manor'. Also, all manorial courts (i.e. courts baron, courts customary and courts of ancient demesne).

\section{CONSEQUENCES OF ABOLISHING LEGAL CONCEPT OF A MANOR}

If the legal concept of a manor is abolished, the consequences will, actually, be few. As to these:

\section{(a) Rents \& Revenues}

Jessel, in his work in 1998, considered this. He noted:

Some lords are still entitled to small sums of money, usually, a few pence a year, payable at the manor court by freeholders and leaseholders. They are of little value, now normally worth less than the stamp on the letter that demands or pays them, and they are viewed as a curiosity. ${ }^{155}$ (italics supplied)

More than 20 years have passed since Jessel wrote and it is asserted that all manorial rents are now nominal and no manorial courts have been operating since 1977 (i.e. to deal with legal proceedings). Thus, abolition of the legal concept of a manor will be negligible in relation to the same. Jessel also considered the following in connection with manors:

- Manorial court fines \&amerciaments. These are of no application today since no manor court as such now sits to conduct legal proceedings; ${ }^{156}$

- Manorial reliefs \&heriots. These are death duties connected to the manor. All are now extinct; ${ }^{157}$

- Manorial fines due to the lord by an incomer on admittance. All are now extinguished; ${ }^{158}$

- Fines on the grant (or assignment) of manorial leaseholds. These are now nominal, to the extent they still exist; ${ }^{159}$

\footnotetext{
${ }^{152}$ Jessel, n 2, p 375 'These did not lose their jurisdiction under the [AJA 1977] and so may still have legal powers. At least one, Portland, was expressly preserved.'

${ }^{153}$ Any ability to fine or amerce by such manorial courts would also, ipso facto, be abolished. Jessel, n 2, p 232 'Any jurisdiction to fine or amerce which still remained [pre-1977] was abolished by [AJA 1977, s 23] since fixing a penalty is determining a legal proceeding.'

${ }^{154} \mathrm{Jessel}, \mathrm{n} 2$, p xii 'many of them [i.e. the legal concepts relating to the manor] are worn out and obsolete.'As long ago as 1896, Howlett, n 119, stated: 'Centuries have robbed the manor of much of its importance...'.

${ }^{155}$ Ibid, p 230.

${ }^{156}$ The only 'manor' court still operating (although it is, actually, franchisal) is the court leet of Laxton (maximum fine is $£$ 20). See McBain, $\mathrm{n} 1, \mathrm{p} 125$. However, this is a minor criminal court.

${ }^{157}$ Jessel, n 2, p 236 'Copyhold reliefs and heriots were abolished under s 138 of the 1922 Act (rep). That section also provides that 'all manorial incidents of a like nature affecting any other land' should be extinguished in the like way. 'Other land' must mean leasehold and freehold land, and accordingly all reliefs and heriots must now be extinct.' For the older law on reliefs and heriots, see Fisher (in 1794), n 30, pp 70-6.

${ }^{158}$ Law of Property Act 1922, s 138 (rep). This would appear to cover both copyhold and freehold manorial fines. For copyhold, there were 3 types of admittance: (a) on voluntary grant; (b) on surrender from the former tenant; (c) on descent from the ancestor. See Fisher (in 1794), n 30 , ch 1 .
} 
- $\quad$ Rovalties/Commissions. Jessel referred to these. However, these are contractual royalties, not manorial rents. Thus, any abolition of the legal concept of a manor would not affect them; ${ }^{160}$

- Manorial rentcharges. These are now nominal ${ }^{161}$ and no new rentcharges (with limited exceptions) can be created post-1977; ${ }^{162}$

- $\quad$ Rentservices. These, so-called because there was a service such as fealty attached to it, include: (a) where the Law of Property Act 1925, s 153 applied (however, this section has now been repealed) ${ }^{163}$ (b) pre-1189 copyhold or pre-1290 freehold rents (where the sum would be nominal); ${ }^{164}$ (c) fee farm rents; ${ }^{165}$ (d) chief rents; ${ }^{166}$ (e) quitrents (these were extinguished under the Law of Property Act 1922 both copyhold and (likely) freehold). ${ }^{167}$

Jessel noted that the Law of Property Act 1922, s 138 (now repealed) temporarily saved certain incidents. Namely, quitrents, chief rents and similar payments, fines, reliefs, heriots, dues, some forfeitures and timber rights. However, after 1950:

no payments in relation to manorial incidents have been due except in the rare cases where the lord and former tenant agreed on a permanent rentcharge [which would now be nominal] ${ }^{168}$

Thus, abolition of the legal concept of a manor will have (in practice) almost no effect in respect of any rent or revenue passing to a lord of the manor, since the same have been abolished or are nominal. However, it is asserted that legislation should provide (for the avoidance of doubt) for the abolition of all:

- manorial fines and amerciaments (court and otherwise); ${ }^{169}$

- manorial rentcharges; ${ }^{170}$

\footnotetext{
${ }^{159}$ Jessel, n 2, p 237 'Fines could and can be charged on the grant or assignment of leaseholds. On the grant they are usually called premiums and are common. Section 11 of the Law of Property Act 1925 [rep] allows the landlord to charge a fine when the tenant assigns where the lease has expressly provided for it, and although rare this sometime happens. If therefore there was an ancient manorial lease of the type described below which reserves the right to a fine on death or assignment, then it may still be due and payable in the manorial court but such cases must be very rare.' Jessel also referred to the Landlord and Tenant Act 1927, s 19(1).

${ }^{160} \mathrm{Ibid}$, 'The original meaning of royalty was similar to franchise....In the context of the manor royalty normally relates to minerals. It does not appear different from a contractual royalty although some royalties, such as toll of tin in certain Cornish manors, may derive from custom. In Cornwall tinners have a right, known as tin bounding...This involves the right under the stannary laws to mine tin whether or not the lord, as owner of the property in the minerals, or the surface owner, gives permission. The person exercising the right must make a payment determined by custom.' It should be noted that tin bounding is now obsolete. Thus, no royalty is payable.

${ }^{161}$ Jessel noted that manorial rentcharges could arise, in particular: (a) under the Inclosure Act 1846, s 5 [rep], where a lord would be otherwise entitled to an allotment of land, he could receive a rentcharge instead; (b) under the Copyhold Act 1894, ss 15 \& 16 [rep], compensation payable to the landlord on enfranchisement of the copyhold could be a rentcharge (if more than $£ 1$, it could be an annual sum that varied with the price of corn); (c) under the Law of Property Act 1922, ss 138 \& 139 [rep], compensation could also be a rentcharge, either one that terminated after 20 years or it was a perpetual one.

${ }^{162}$ Jessel, n 2, p 240 'Under the Rentcharges Act 1977, no new rentcharges can be created (with limited exceptions) and existing rentcharges will be extinguished in ...2037. However, the Act does not extinguish rentcharges created under any Act of Parliament providing for the creation of rentcharges in connection with the execution of works on land (whether by way of improvements, repairs or otherwise) or the commutation of any obligation to do any such work....quitrents are precisely that so that rentcharges under the Copyhold Act [1894, rep] or the 1922 Act may continue to run even after 2037.'

${ }^{163}$ Ibid, p 241 'Under [the LPA 1925, s 153] where the term was for not less than 300 years and at least 200 years have still to run, where the rent is a pound or less and has not been collected for 20 years and the lease does not contain a right of re-entry, then the lessee can enlarge the lease into a freehold. In many cases that has never been done, often because the lease itself has been lost and no one knows whether it qualifies or not. If the lord can prove his rights he can demand the rent, but as this is usually only a few pence it is hardly worth doing.'

${ }^{164}$ Ibid, p 242 'rents could be payable for freeholds and, until 1926, copyholds. As copyholds could not (with rare exceptions) be created after 1189, and freeholds not after 1290 , such rents must either themselves be ancient or replace other ancient rights.'

${ }^{165} \mathrm{Ibid}$, 'A fee farm was an inferior freehold that was like a lease in that it reserved not just a nominal rent, but a substantial one of between a half and a quarter of the full annual value of the land.'

${ }^{166} \mathrm{Ibid}$, 'A chief rent is a rent payable by a freeholder, and in areas where rentcharges are common, the term is often used to refer to them but its likely origin is a rent payable to a chief lord, or superior lord of the freehold.'

${ }^{167}$ Ibid, p 243. 'All copyhold quitrents were extinguished under the 1922 Act [i.e. Law of Property Act 1922, s 138, rep]. The effect of s 138 is probably to extinguish freehold quitrents as well. There is a view that they survived, but I do not know of any cases where an undoubted quitrent is still paid.'

${ }^{168}$ Ibid, p 245. See generally, for the older law on rents, Fisher (in 1794), n 30, p 69.

${ }^{169}$ If manorial courts are abolished (see 11(d)), obviously, all court fines and amerciaments will go.

${ }^{170}$ See $\mathrm{n}$ 161. Sweet, $\mathrm{n} 2$ (writing in 1882)(rent charge) 'A rent charge is where a rent is payable in respect of land to a person who has no reversion in it, and a right of distress is given him by express agreement between the parties: as where a man (since Quia Emptores [1290]) conveys land in fee to another, reserving to himself and his heirs a certain rent with a right of distress, or if a man seised of land grants to another a yearly rent issuing out of it with a clause of distress.' Today, there is no right of distress. Therefore, the quitrent, as formally defined, would appear to no longer exist as such.
} 
- manorial rentservices, including all pre-1290 copyhold or freehold rents, fee farm rents, chief rents and quitrents,

all of which would be nominal today, anyway, to the extent they still exist. An exception would be where legislation provides for a rentcharge. ${ }^{171}$ However, these applied to land improvements on (and attached to) landed estates and not to a 'manor' as such.

\section{In conclusion, all manorial rents and revenues are either extinct, extinguished or wholly nominal. Thus, the abolition of the legal concept of a manor should have no practical effect.}

\section{(b) Ecclesiastical Manorial Rights \& Obligations}

If the legal concept of a manor is abolished, this might have legal effect in respect of the manorial rights and obligations of some lords of the manor concerning some Church of England ('C of E') churches. As to these:

- Advowsons. When lords of the manor built churches on their land they, sometimes, had a right of advowson. That is, the patronage to present (that is, to appoint) a clergyman (also called the vicar, parson, priest or rector) to that church. ${ }^{172}$ The Patronage (Benefices) Measure 1986 provides that all advowsons are now in gross (also, that they cannot be sold, see s 3). As it is, it may be appropriate to abolish, in any case, all advowsons (including Crown ones) since the patron is, today, often not a practising member of the $\mathrm{C}$ of $\mathrm{E}$. This would leave the appointment of clergy in the hands of the local bishop - a position (likely) reflecting Anglo-Saxon times; ${ }^{173}$

- Pew, Chancel or Other Church Repairs. A lord of the manor, as such, might have the right to a pew ${ }^{174}$ (in perpetuity or on payment of a rent). Or, to an aisle, chapel, vault etc. in a church. ${ }^{175} \mathrm{He}$ does not have, thereby, any freehold in the same but is responsible for repair. ${ }^{176}$ Abolition of the legal concept of a manor should terminate any such right or obligation. This, (likely) would be a relief to many lords of the manor who do not attend the church and yet find them themselves with a bill for upkeep. Abolition would not affect private owners of pews, ${ }^{177}$ vaults etc. Only those holding rights (and having obligations) qua lord of the manor;

\footnotetext{
${ }^{171}$ Under Victorian legislation, persons could improve land (in respect of drainage etc) and the cost (the debt) incurred as a result of such an improvement could attach to the land as a form of rentcharge. See e.g. Improvement of Land Act 1846, s 51 (costs of improvements approved by Inclosure Commissioners in respect of inclosed land).

${ }^{172}$ Jessel, n 2, pp 307-8 'When lords built churches for their own house or estate priest, they naturally had the right to appoint whoever they wished, providing they had been ordained. Where there was originally no estate church, the right to appoint clergy belonged to the bishop or the king and many advowsons still belong to the diocese or the Crown for that reason.' For an early text on advowsons, see J Mirehouse, Law of Advowsons (1824).

${ }^{173}$ Mirehouse, $\mathrm{n}$ 172, p 2 'In the earliest Saxon times, the interest and government of churches were exclusively in the bishop...'

${ }^{174}$ Generally, as Williams (in 1880) noted, n 24, pp 361-2 a right to a pew in a parish church was by virtue of a grant from the bishop (called a faculty) and 'in some cases a prescriptive right to a pew, as appurtenant to an ancient messuage in the parish. The evidence, however, must consist not only of the occupation of the pew for a time which will afford presumptive evidence of immemorial enjoyment, but also of proof of the repairs of the pew having been invariably paid for by the person who claims the pew as appurtenant to his dwelling house, or by his predecessors in title....A right similar to that of a pew is a right of burial in a particular vault, in a church or churchyard.'

${ }^{175} \mathrm{Jessel}$, n 2, pp 321-2 'In the Middle Ages the general custom of parishes was that the congregation were responsible for repair and maintenance of the nave of the church and the rector for the chancel. Both are now normally looked after by the parochial church council. However, in impropriate parishes the liability of the rector became that of the lay rector and still exists. Normally, this is attached to land. In theory this would be to the glebe, but that has long ceased to be separately identifiable (unless part of it was kept for the vicar's endowment) and so in impropriate rectories where the rectory is appurtenant to the manor, the liability for chancel repairs attaches to the whole of the demesne as it existed at the Dissolution [of the Monasteries 1536-41]. If a part of the demesne is sold off, one of two things happens. Either the liability is apportioned so that the purchaser of one per cent of the demesne will take on one per cent of thecost of chancel repairs. Or the lord [of the manor] will indemnify the purchaser and retain the whole liability. But that is a private arrangement between landowners. It does not affect the church and so the parochial church council is legally entitled to sue the landowner of any part of the former demesne (however small) for the whole cost of the repairs. He may be able to recover a contribution from the other landowners. In many parishes this is a real problem, and in recent years various proposals have been made to overcome it, but none has been generally accepted as fair to everyone involved.' See also Ibid, p 318. Sweet (writing in 1882), n 2 (impropriation) 'Impropriation is where a rectory or tithes belong to a lay person called the impropriator...Etymology. Said to be derived from the latin in proprietatem, because the living is held as a lay property.' (italics supplied). See also Williams (in 1880), n 24, pp 360-2.

${ }^{176}$ Ibid, p 318. For an early text on church repairs, see R Swan, Church Repairs and the Remedies for Enforcing them (1841).

${ }^{177}$ It may be noted that churches and chapels in England did not have seats for the congregation until the $15^{\text {th }}$ century and that, initially, such were movable. Further, cathedrals, generally, permitted no assertion of private rights that were legally enforceable. Thus, any abolition (or restriction) of such rights will assimilate parish churches to cathedrals and help consistency. It may also be noted that the assertion of legal rights to pews tended to be in vogue in the Victorian era, where class distinctions were important. For legal texts see A Heales, History and Law of Church Seats or Pews (1872) and, for older works, see Sweet \& Maxwell, n 25, vol 2 (English Law from 1801 to 1954) (heading, ecclesiastical law, 'pews').
} 
- $\quad$ Tithe, Modus. This was a form of church tax. The right to the tithe could be acquired by others. The most usual were impropriate rectors. ${ }^{178}$ The Tithe Act 1836 converted most tithes into a variable rentcharge. Such were, later, assumed by the Government (who compensated the $\mathrm{C}$ of $\mathrm{E}$ and other tithe owners) and, pursuant to the Tithe Act 1936, converted the same into redeemable stock which was abolished by the Finance Act 1977, s 56 (rep). However, it is conceivable that some forms of tithe (or payment in lieu) may still exist - such as modus. ${ }^{179}$ Abolition of the legal concept of a manor should terminate the right of a lord of the manor to such. In any case, it may be appropriate for legislation to abolish all tithes, moduses and any ecclesiastical annuity rentcharge - all of which are (likely) nominal today; ${ }^{180}$

- Gifts for Churches Act 1811. Like the Schools Acts 1841-52, ${ }^{181}$ the Gifts for Churches Act 1811 provided that manorial land could be set aside for the building of a church. For the same reasons as the Schools Acts, this legislation should be abolished (since it is no longer needed) with the Reverter of Sites Act 1977 applying to any extant sites where the original owner cannot be traced.

In conclusion, abolition of the legal concept of a manor would have little practical effect on ecclesiastical affairs, save for chancel etc. repairs.

\section{(c) Appointment}

In the past, lords of the manor had the right (or claimed the right) to appoint persons to certain offices, such as the steward of a court customary (for copyholders, now obsolete). Or, as a sexton (a manager who maintained the fabric of the church). Or, as a master (manager) of a hospital. ${ }^{182}$ Such are now rare and of nominal financial worth. ${ }^{183}$ If the title 'lord of the manor' is abolished, such a right will also go. Abolition of such a right is (unlikely) to be contentious. Further, since lordships can be held in gross and can be purchased by persons with no local interest, such would seem appropriate. Otherwise, the appointee can be unsuitable or without knowledge of the relevant subject matter.

In conclusion, abolition of the legal concept of a manor would have little practical effect on any rights of appointment still exercised by a lord of the manor.

\section{(d) Manors of the Duchies of Lancaster \& Cornwall}

Both these duchies have manors. Indeed, sub-honors and honors (i.e. groups of manors). Any abolition of the concept of a manor would affect them. In the duchy of Cornwall, 17 of the manors were called 'assessionable manors'. That is, they had no copyhold tenants as such. Rather, they had 'conventionary tenants' whose holding was more akin to a leasehold with a right to renew on payment of a fixed premium. However, such were enfranchised to free tenants by the Cornwall (No 2) Act 1844, also, called the Assessionable Manors Act 1844. ${ }^{184}$ Abolition of the legal concept of a manor would not affect any right to minerals, as set out in that Act, for which see $15 .{ }^{185}$

\footnotetext{
${ }^{178}$ GWO Addleshaw, Rectors, Vicars and Patrons in Twelfth and early Thirteenth Century Canon Law (1956), p 6, 'Ninth and tenth century bishops and abbots had, often very improvidently, parted with their share in a church's tithe to laymen; and this was the origin of much lay tithe-owning.' For the older law on tithes see PW Millard, The Law relating to Tithes ( $3^{\text {rd }}$ ed, 1938).

${ }^{179} \mathrm{Jessel}, \mathrm{n} 2$, p 323 'Along with tithes were other similar payments known as modus (which had to be created before 1189 as a fixed commutation of the previously variable tithe) and corn rents. In theory both of these were included in the reforms of 1836 and 1936 . In practice a few small tithe payments were not caught, probably because they were not worth the cost of converting to the new system, and have continued to be payable to the present time.'

${ }^{180} \mathrm{Ibid}$, 'There used also to be annuity payments or rentcharges payable to churches by reason of tenure. These may derive from cases where before 1290 [the Statute of Quia Emptores] church land was alienated by subinfeudation at a rent. They are rare.' For current tithe legislation, see Halsbury, Statutes (4th ed), vol 14, which refers to the Tithe Acts 1536, 1832, 1836, 1839, 1860, 1936 and 1951 as well as the Tithes and Offerings Act 1548.

${ }^{181}$ For analysis, see McBain, $\mathrm{n}$ 1, pp 76-7.

${ }^{182}$ Jessel, n 2, pp 281-2 cited old Victorian cases.

${ }^{183}$ Jessel, p 283, mentions the Padstow Harbour Revision Order 1987 (a $10^{\text {th }}$ commissioner to be appointed by the lord of the manor of Padstow).

${ }^{184}$ See G S McBain, Time to Abolish the Duchy of Cornwall ? (2013) Review of European Studies, vol 5, no 5, pp 40-58. For the list of 17 assessionable manors, see the Act, schs 1 and 2 (the latter listed manors sold by the duchy). Thus, sch 1 refers to the 11 manors of Helstonin Trigg, Penmayne, Tintagel, Restormel, Penlyne, Penkneth, Talskedy, Liskeard, Rillaton, Stoke Climsland and Trematon. Sch 2 refers to the 6 manors of: Tewington, Tybesta, Moresk, Tywarnhaile, Helston-in-Kerrier and Calstock. It may be noted that the Copyhold Act 1894 (which consolidated prior Acts and dealt with enfranchisement) did not apply to the duchy of Cornwall, see Adkin, n 30, pp 194, 240.

${ }^{185}$ See also Jessel, n 2, p 379. Also the Duchy of Cornwall (No 2) Act 1844 discussed in McBain, n 184, pp 14-5.
} 


\section{(e) ParliamentaryManors}

A member of Parliament (MP) wishing to resign, applies to the Chancellor of the Exchequer to be appointed to be steward (i.e. bailiff) of the: (i) manor of Northstead; or (ii) the Chiltern hundreds of Stoke, Desborough or Burnham. ${ }^{186}$ Abolition of the legal concept of a manor would affect this only nominally since there are no incidents attaching to such stewardship. Alternatively, exemption (or the resignation of an MP) could be provided for. $^{187}$

In conclusion, if the legal concept of a manor is abolished this, generally, will have little practical effect on: (a) any manorial rents or revenues - all of which are (almost certainly) now nominal; (b) eccelesiastical matters; or (c) powers of appointment. Nor on duchy or parliamentary manors (for which an exception could be made, if necessary).

\section{CLASS 3 MANORIAL INCIDENTS - FAIRS\& MARKETS ${ }^{188}$}

\section{(a) Rise and Decline of Fairs \& Markets}

Probably, in Anglo-Saxon times, the Crown asserted the prerogative (that is, the sole right or privilege) to hold markets and fairs. The former were regular markets. The latter were intermittent (often, annual) markets to which 'foreigners' (i.e. non-residents as well as those from abroad) also came. The franchise to hold a market or fair was popular from the $12^{\text {th }}$ century - when fairs in England began to expand rapidly - until the $15^{\text {th }}$ century, when fairs began to decline in importance. Lords of the manor (often) acquired a franchise from the Crown to operate a market or fair since it could be lucrative to them - given that they could (usually, as part of the franchise) impose various tolls on stallholders and others (such as for stallage, piccage, pennage etc). ${ }^{189}$

- Ending of Fair Courts. The decline in fairs is reflected by the decline in fair courts (courts of pie powder, pie poudre) which became few and far between in early Victorian times, extinct by $1898^{190}$ and inoperable by the Administration of Justice Act 1977, s 23; ${ }^{191}$

- Suppression of Fairs. The reason why was a practical one. Goods sold at fairs were those which, in times past, could not be obtained at local markets. However, this became not so with the advent of better roads and railways. Also, when the fair opened (usually) the local market was required to close. This engendered rivalry with local people winning in the end (sometimes, by buying out the right to the fair and suppressing it). Further, many fairs were suppressed under the Fairs Act 1871 (still extant) due to unruly behaviour. ${ }^{192}$

Franchises to lords of the manor to hold markets and fairs declined by the 15th century, with town corporations acquiring (or taking over) such, thereafter. Further, in Victorian times, legislation took over wholly from franchises of the Crown prerogative. ${ }^{193}$

\section{(b) Abolishing manorial right to hold Fair or Market}

Manorial rights still extant include the right of a lord of a manor to hold a fair or a market, see 6(a)(iii), and these are subject to registration under the Land Registration Act 2002. ${ }^{194}$ However, it is asserted that any

\footnotetext{
${ }^{186}$ Ibid, p 380.

${ }^{187}$ Ibid, p 380, also noted that Sir Arthur Lee gave his estate (together with the manors of Ellesborough Chequers and Mordaunts and of Great Kimble and Little Kimble in Buckinghamshire) for a residence for the prime minister. This was confirmed in the Chequers Act 1917. Abolition of the legal concept of a 'manor' would not affect this Act.

${ }^{188}$ See generally, McBain, n 14(e). See also GS McBain, The Strange Death of the Law Merchant [2016] International Law Research, vol 5, no 1, pp 32-151 ('McBain Law Merchant'). It discusses the early law of markets and fairs. The National Archives contains charters for markets and fairs from 1199, see First Report of the Royal Commission on Market Rights and Tolls (1889). For the standard text on markets and fairs see JG Pease and H Chitty, Law of Markets and Fairs ( ${ }^{\text {st }}$ ed, 1899 and subsequent editions). See also Williams, n 24, pp 293-300.

${ }^{189}$ Jessel, n 2, p 327 'Market franchises were usually granted to lords of manors who could exercise control through their courts and landholdings, but markets could be given to anyone such as burgesses [i.e. theresident citizens] of a town....A franchise on its own is of little value...Market toll...is not automatically implied in a market franchise, and must be specifically mentioned in the grant... '. For market tolls, see Pease \& Chitty, n 188, ch 4 who noted (in 1889), p 55, that the usual payments made to the owner of a market were toll (a reasonable sum of money due to the owner of the fair or market on the sales of good within the fair). Also, stallage (the right to erect a stall, or standing room, for cattle or goods in the market) and piccage (i.e. stallage where the soil is broken). Also, pennage (a right to erect animal pens).

${ }^{190}$ The last fair court is said to have been at Hemel Hemsptead in 1898. See McBain Law Merchant, n 188, p 136 and Pease \& Chitty, n 188, p 6.

${ }^{191}$ See 11(d)

${ }^{192}$ See Pease \& Chitty, n 188, ch 94-5 and later editions.

${ }^{193}$ Ibid, p 19 (writing in 1899) 'From the end of the twelfth century to the year 1516 all grants of fairs and markets were made by charter. Since that date all such grants have been made by letters patent. Since 1846 few, if any, [one would suggest, no], grants of market rights have been made by the Crown.' There is also no evidence of the Crown now running fairs or markets itself (so-called, king's fairs or king's markets). Ibid, $\mathrm{p} 18$.
} 
manorial right to a fair or market should be abolished since no such manorial fairs or markets appear to presently exist, acting pursuant to any Crown franchise.

- Indeed, all fairs (of which there are, likely, very few now) ${ }^{195}$ and markets now appear to be wholly regulated by general legislation today and not even by local or private legislation. ${ }^{196}$ A major factor to this was the power granted under the Public Health Act 1875 to district councils to establish markets in their districts. Also, there were decreasing profits arising to market (and fair) owners due to the expense of operating the same - including increasing costs in respect of regulation, health and safety; ${ }^{197}$

- Thus, even though such a manorial right may exist in theory, it does not occur in practice. Not least, since the operation of a fair or market tends to be onerous in that: there must be land available, the safety of persons visiting it must be assured, access by cars and persons must be agreed with the police, there is no automatic right to impose tolls (the Crown grant must specifically provide for this) etc. Thus, while such a right might be (theoretically) asserted by a lord of the manor, in practice, it has, today, become (often) long obsolete. ${ }^{198}$

In conclusion, any manorial (actually, franchisal) incident to hold (operate) a fair or market should be abolished - such matters now being, more appropriately, regulated by legislation rather than the Crown prerogative. As a result, the Crown prerogative to operate a fair or market (and any franchise of the same) should now be abolished generally, see 24.

\section{CLASS 3 MANORIAL INCIDENTS - SPORTING ${ }^{199}$}

(a) Introduction

As noted in 6(iii)(a), a manorial incident still extant -one subject to registration pursuant to the Land Registration Act 2002 - are sporting rights. However, it should be noted that there has been a change in the concept.

- In medieval times, the lord of the manor retained such a right over his demesne that had become manorial waste (commons) since the purpose of his hunting was necessity - to provide daily or weekly food for the manorial table. However, since Victorian and Edwardian times, the purpose has been pleasure not necessity;

- Also, today, in practice the hunting of animals and birds by lords of the manor has been much curtailed - as a result of a diminution in the number of lords of the manor, dis-interest in exercising such a right, common land becoming built up, the outlawing of fox hunting etc. ${ }^{200}$ It is likely that this will (much) increase in the future, with lords of the manor, as such, becoming less and less interested in the same. Not least, because of the difficulties involved in exercising such rights in practice.

It should be noted that one is referring, in this context, to manorial rights that have to be proved to exist. Not to contractually agreed sporting rights which members of the public (or clubs) have over private land (shooting estates etc) that does not comprise manorial land.

\section{(b) De-linking Sporting Rights from Lord of the Manor}

If the legal concept of the manor is abolished, any manorial right of a lord of the manor - whether such right exists as a result of his being the holder of manorial land or in gross - should be altered. It should be held instead qua land holder (or holder in gross) and not qua lord of the manor. Further, since such rights - while they may

\footnotetext{
${ }^{194}$ Halsbury Laws, n 62, vol 32, para 95 'The rights must, however, be registered. Manorial rights and franchises which are not registered before 13 October 2013 are liable to be overridden by first registration or registered disposition of the land to which they relate.' Reference is made to the Land Registration Act 2002, s 117(1), sch 1, paras 10 \& 11 and to sch 3, paras $10 \& 11$.

${ }^{195}$ Fairs proper refer to those where goods are sold and not to fun fairs, ad hoc fairs (wakes, car boot fairs), trade and agricultural fairs etc. since there was no charter or, if such, there was no sale of goods. See McBain Law Merchant, n 188, pp 72-4.

${ }^{196}$ See 24

${ }^{197}$ See Pease \& Chitty, n 188, p 19.

${ }^{198}$ As for cases, Jessel, n 2, p 327 referred to Spook Erection Ltd v SS for the Environment and Cotswold District Council [1988] 2 AE 667. Also, Gloucestershire CC v Farrow [1982] 2 AE 1031 (a manorial market needed planning permission). These cases are now 30 years old. Much has happened in the interim with available land for holding a market, often, having been built over and the costs of establishing and operating a market having increased. Thus, today, there is little financial benefit in re-establishing a manorial market in any case.

${ }^{199}$ See generally, RS Nolan, Sporting Rights and Relevant Matters (1914). Ibid, p 6 'A lord of the manor has as such no right to the game on the freeholds of the manor [cf. if a warren]...But the lord of the manor has the right to the game on the commons of the manor.'Also, many texts on game referred to in Sweet \& Maxwell, n 25, vols 1 \& 2, including BW Adkin, Law of Forestry, Trees, Trespass and Game (1914). Williams (in 1880), n 24, p 152 'The lord is also entitled, as owner of the soil, to sport over the waste...'.

${ }^{200}$ Other hunting of animals such as deer hunting (cf. deer shooting on private estates) and hawking etc have also declined as manorial pursuits. For how game was dealt with in earlier law see W Nelson, The Laws concerning Game (1762).
} 
be registered, in practice, are (often) never exercised - there should be a legal requirement for the renewal of the same (say, every 10 years) in order for the registration to remain valid. This also reflects the real legal basis for such manorial rights being permitted in the first place. That is, as a necessity (see (a) above). This would also have the benefit of such rights, in time, moving to become contractual rights (as with private sporting rights) as opposed to attaching to the land and 'clogging' the title.

In conclusion, any manorial incident to exercise a Class 3 sporting right should be de-linked from the holder of the same being lord of the manor, with the legal concept of a manor (including the title 'lord of the manor') being abolished. Further, any registered sporting right should be subject to renewal every 10 years, to prevent such rights clogging land title when, in fact, they are never exercised and, thus, are obsolete (spent) in practice.

\section{CLASS 3 MANORIAL INCIDENTS - MINES \& MINERALS ${ }^{201}$}

\section{(a) Introduction}

Mines and mining were an important source of income in the past as well as being, in the case of coal, a necessity for heating. Coal mining became even more important with the advent of the Industrial Revolution. As well as coal mining, there were, also, other minerals mined in England and Wales in the past. Thus:

- $\quad \underline{\text { Tin}}$. From ancient times - tin mining occured in Devon and Cornwall. This was regulated by its own stannary laws and customs and disputes were determined in its own stannary courts. ${ }^{202}$ Tin mining (tin bounding) was undertaken by individual miners opening, and working, their own seams;

- $\quad$ Lead. There was also lead mining in Derbyshire. This, also, was undertaken on an individual basis and it was regulated by its own laws and barmote courts; ${ }^{203}$

- $\quad$ Gold \& Silver. There were also gold and silver mines. ${ }^{204}$ However, the Crown had a sole prerogative over these and did not franchise the same - save (possibly) to the duchies of Cornwall and Lancaster (although no charter to the same appears to expressly state this). ${ }^{205}$

In the case of coal mining, there were also some local customs. For example, in Forest of Dean. Here, besides coal, mining for ochre (a clay pigment used for house, and artists', paints) was undertaken as well as for iron. ${ }^{206}$

\section{(b) Current Position Generally}

The coal industry, scarcely, operates in the UK today and there are now no deep mines as opposed to open (surface) mines. Further, coal powered fire stations will end by 2025, if not before. Thus, coal mining has, virtually, ended as a result of environmental and practical grounds - its place being taken by oil, gas, renewable and nuclear energy (the latter, itself, in decline).

- $\quad$ Tin \& Lead. Tin mining (in Cornwall) ended by 1998 and lead mining (in Derbyshire) by $1939 .{ }^{207}$ Thus, all the stannary customs and courts in respect of tin and lead mining, which related - it should be noted - to the exploitation of seams by individuals (for which a royalty was paid) are now obsolete.

\footnotetext{
${ }^{201}$ See generally, W Arundell, Law of Mines and Mining Companies (1863); W Bainbridge, Law of Mines and Minerals (1900 ed), PG Bamber, Manual of Modern Mining Law and Practice (1930); T Barlett, Law of Mining (1850); D Bowen, Mines and Quarries Acts (1923); ASC Carr \& W Fordham, Recent Mining Legislation (1931); JH Cockburn, Law of Coal, Coal Mining and the Coal Trade (1902); RP Collier, Treatise on the Law relating to Mines ( $2^{\text {nd }}$ ed, 1855); RF MacSwinney, The Law of Mines, Quarries and Minerals $\left(5^{\text {th }}\right.$ ed, 1922); J Pettus, Fodinae Regales or History, Laws and Places of the Chief Mines and Mineral Works in England, Wales and the English Pale in Ireland $\left(1^{\text {st }}\right.$ ed 1670, last 1706); A Rogers, Law of Mines, Minerals and Quarries ( $2^{\text {nd }}$ ed, 1876); T Tapping, Statutes for the Registration of Ore Mines and Colleries with notice of the Truck Act (1861). For a number of texts on the older Coal Mines Acts (now repealed), see Sweet \& Maxwell, n 25, vol 2, (mines and minerals).

${ }^{202}$ See, in particular, T Pearce, Laws and Customs of the Stannaries in the counties of Cornwall and Devon (1725). Also, texts cited in Sweet \& Maxwell, n 25, vol 1 (mines). See generally, McBain, n 184, pp 12-3. It may be noted that the last mine in Cornwall (South Crofty tin mine) closed in 1998 and the last copper mine (Dolcoath mine) in 1920-1). Ibid, p 13, n 145. Drakeslands mine in Devon, which opened to mine tungsten in 2015 , no longer operates.

${ }^{203}$ See GJ Steer, Complete Mineral Laws of Derbyshire (1734), T Tapping, Derbyshire Mining Customs and Mineral Courts Act 1852 (1854) and T Tapping, High Peak Mineral Customs and Mineral Courts Act (1851). Also, texts cited in Sweet \& Maxwell, n 25, vol 1, (mines). For the barmote courts, now obsolete, see GS McBain, Abolishing various Obsolete Courts (2012) Coventry LJ, vol 17, no 1, pp 46-8.

${ }^{204}$ CEM Edwards, Gold Mines Law(England)(1888). Also, His Majesty's Mines Royal in the Principality of Wales (1642). See also McBain, n 14(b), pp 100-3 (royal mines).

${ }^{205}$ McBain, n 184, p 9. Cf. McBain, n 14(b), p 102, n 46 and the Limitation Act 1980, s 37(6).

${ }^{206}$ See WO Hart, The Free Miners of the Forest of Dean (1951) and JG Wood, Laws of Dean Forest and the Hundred of St Briavels (1878). See also McBain, n 1, pp 60-1.

${ }^{207}$ The last lead mine in Derbyshire, Millclose mine, closed in 1939. See also McBain, n 203, p 47, n 185.
} 
- Coal - Forest if Dean. As to coal mining in places where local customs still prevail, reference may be made to the Forest of Dean. Here, the Crown owns any mines. However, a person can mine if they satisfy the requirements of being a 'free miner' and pay (since 1997) a licence fee (of £50). ${ }^{208}$ Today, there are no more than 7 coal mines being worked (i.e. mined) by up to 150 individuals working part time in the Forest of Dean and, on environmental - as well as on safety grounds - it is asserted that these should end. ${ }^{209}$

Thus, generally, all this mining law, it is asserted - which comprises local customs - should be abolished and the general law now applied. In practice, abolition of these local customs will have little (or no) effect on anyone save for the Forest of Dean where it will affect some coal miners. However, generally, any local right to mine coal (whether customary or pursuant to legislation) should now end on environmental grounds.

In conclusion, all local mining customs and law should be abolished. This, on the grounds of there being obsolete and their purpose (individual sustenence and livelihood) having ended. As a result, the general law on mines and mining will apply.

\section{(c) Manorial Right to Mine \& Minerals - Lord of the Manor}

Lords of the manor (often) retained rights to mines and minerals on manorial land occupied by villein (copyhold) tenants as well as on manorial waste. The reason was, in earlier times, necessity. They needed coal to heat their houses. Also, they extracted gravel to pave the manorial roads leading to and from the manor as well as within.

- Today, the general position as to mines and minerals is that - in respect of those under a freehold tenement in a manor - there is a (rebuttable) presumption that the possession of - and the property in them is in the tenant; ${ }^{210}$

- In the case of copyhold tenants, it may be noted that the mines below their soil belonged to the lord. However, since the estate of the copyholder lay in the soil, the lord could not access the same in the absence of custom (or an enabling power) without committing trespass. ${ }^{211}$

Today, lords of the manor do not exercise their right to mine coal, for the reasons given above. Further, gravel mining for manorial roads, also, is rare or non-existent (it was only a personal right accorded to the lord of the manor anyway for his roads). ${ }^{212}$ Modern roads, today, are of tar macadam and they need to be professionally laid and maintained with particular types of gravel. Further, highways legislation has taken over most manorial roads which the general public drive along. Mining for sand by the lord - for maintaining his manorial house and (possibly) for maintaining manorial roads - is also obsolete.

- Therefore, there would seem to be good grounds to exclude any right of the lord to mine coal (as well as tin, lead and iron) on environmental grounds;

- Also, to require any right to mine gravel and sand to be subject to registration and renewal of the same (say, every 10 years) in order to remove rights not actually exercised from 'clogging' the title register.

Given that extracting gravel and sand can also be environmentally damaging, consideration should, also, be given whether, today, it is appropriate for any manorial right to mine or to minerals continue to exist.

In conclusion, any manorial right in the lord of the manor to mine and minerals should no longer include coal, tin, lead and iron (also, possibly, gravel and sand extraction). Indeed, consideration should be given to wholly abolishing any such right, leaving the general law, today, to govern such matters.

\footnotetext{
${ }^{208}$ A 'free miner' is required to be: (a)a person over 21; (b) who is born, and lives, in the hundred of St Briavels; and (c) who has worked for a year and a day in a mine within the hundred. Free miners were exempt from nationalisation in the Coal Act 1938 and the Coal Industry Nationalisation Act 1946.

${ }^{209}$ The Dean Forest Acts 1819 \& 1861 deal with mining in the Forest. So too, the Dean Forest (Mines) Act 1838 and the Forest of Dean (Mines) Act 1904. See also the Dean Forest Act 1906 and the Dean and New Forest Act 1808. To mine, a gale rent (that is, a royalty) was payable. See also an article by C Manby on the ancient art of free mining, The Independent, 12th November 2018. Dean Forest also has one iron mine (not presently worked) and 8 small quarries.

${ }^{210}$ Halsbury Laws, n 62, vol 32, para 112. For the legal position in 1880, see Williams, n 24, pp 213-27. Ibid, p 213 'As to freehold lands held of the manor, the lord has no right to the minerals under them. They belong to the freeholder as part of the soil of which he is seised.'

${ }^{211}$ Ibid, para 114 'Mines and minerals under copyhold tenements of a manor belonged to the lord, but, as the estate of the copyholder was in the soil throughout his tenement (except the mines and minerals), the lord, in the absence of [a] custom or other enabling power, could not get them without rendering himself liable to an action for trespass at the suit of the tenant; and this was so notwithstanding that the tenant had let the surface to a third party.' For the legal position in 1880, see Williams, n 24, pp 213-27.

${ }^{212}$ Such rights were intended, originally, for the lord of the manor only for his personal use and to be only reasonably availed of.
} 


\section{(d) Manorial Right to Mine \& Minerals - Tenants}

As well as lords of the manor, tenants could have a right to mine or minerals on manorial waste. This, was given for the performance of their services to the lord. It was called common of digging. Thus, it was, originally granted on the basis of necessity. For example, to extract coal to heat their house. Or to use gravel and sand for repairs to their house. This right was, probably, an extension (or treated as part of) of the right to turbary and to estovers, see 16 \& 17. Williams (writing in 1880) noted as follows:

I now come to the consideration of rights of digging for sand, gravel, coal... right may be established either by prescription, as appurtenant to a tenement for the repair thereof or to be used thereon for any reasonable purposes, or by grant to be appurtenant to a tenement for any such purposes; or, I apprehend, either by prescription or grant, as a right in gross, independent of the enjoyment of any tenement. When a right of this kind is claimed as belonging to any particular tenement, it must, like the claim of estovers or turbary, be of a reasonable kind, and it must be for materials which, when taken, are to be used or consumed upon the tenement of which they are claimed. ${ }^{213}$ (italics supplied)

Today, it is difficult to argue that any such right is a necessity or a service benefit. Further, such extraction can be environmentally damaging. The position, therefore, as to the current worth of such a right is as with the lord of the manor (see above).

In conclusion, any manorial right in the tenant to mine and minerals should no longer include coal, iron, tin or lead (also, possibly, gravel and sand extraction). Indeed, consideration should be given to wholly abolishing any such right to mine and to minerals, leaving the general law, today, to govern such matters.

\section{(e) Duchy of Cornwall - Mines \& Minerals}

Mines and minerals in respect of 17 assessionable manors within the duchy (see 12(d)) are regulated by the Cornwall (No 2) Act 1844 which is, also, called the Assessionable Manors Act 1844. It is still extant.

- Duchy right to Assessionable Manor Mines. Express provision was made in this Act for the duchy to retain rights to mines and minerals under these assessionable manors in respect of conventionary tenants (who were akin to copyhold tenants and, by the Act, became freeholders) with the duchy paying compensation for any damage to the surface; ${ }^{214}$

- Claims barred to Duchy. Any claim by the Duke of Cornwall to a mine is barred by others possessing the land in question and having exclusively worked the relevant mine for 60 years. ${ }^{215}$ Also, any mine where possession of the land above is situated in the county of Cornwall and has been held by others for 100 years. ${ }^{216}$

The Act is not designed to affect the rights of tin miners in Cornwall (albeit, tin bounding - i.e. an individual miner inclosing waste ground for tin mining - is now obsolete, see (a)above) ${ }^{217}$ If the legal concept of a manor is abolished it is asserted that this Act should be repealed - including provisions in respect of mines and minerals relating to these 17 assessionable manors ( 6 of which had been sold by 1844),such that the general law on mines and minerals shall now prevail - as opposed to provision in this Act.

\footnotetext{
${ }^{213}$ Williams, n 24, p 203. Ibid, p 18 'There may also be a prescription for taking sand, gravel, clay, and loam for the repair of the roads or for the improvement of the dominant tenement...'. Digging was for personal consumption and could not be on-sold. Ibid, p 207. Cf. pp 2112 'The right to dig for sand, gravel etc, claimed by one person in the soil of another, must be carefully distinguished from the right of the lord of a manor to dig for the same materials in the waste land of the manor over which his tenants have rights of common of pasture. The lord's right to dig is by virtue of his ownership of the soil; and his ownership of the soil carries with it the usual rights of all owners, so long as the rights of the commoners are not infringed.' (italics supplied)

${ }^{214}$ Sections 53-5. See also McBain, n 184, pp 14-5.

${ }^{215}$ Section 71.

${ }^{216}$ Section 74 'the Duke of Cornwall shall not sue, impeach, question, or implead any person for or in any wise concerning any mines, minerals, stone, or substrata in, upon, under, or of any lands, manors, tenements, or hereditaments whatsoever situate in the county of Cornwall, where such lands, manors, tenements, or hereditaments shall have been held or enjoyed by such person, or any person by, through, or under whom he claims, or any person whomsoever other than the Duke of Cornwall, or any person claiming under him, for a period of [100] years before the filing, issuing, or commencing any action, bill, plaint, information, commission, or other suit or proceeding in respect of such mines, minerals, stones, or substrata, without interruption or disturbance by the Duke of Cornwall, or any person claiming under him, and where such mines, minerals, stones, or substrata shall not have been at any time during the said period of [100 years] worked and gotten, or the tolls, dues, royalties, or other profits thereof received or enjoyed, by the said Duke of Cornwall or some person claiming under him.'

${ }^{217}$ Section 84 'nothing in this Act...shall in anywise prejudice, affect, or extend to any lawful, right, profit, privilege, or easement to which the tinners of the county of Cornwall are or claim to be entitled, as such tinners, under or by force of any statute, custom, prescription, or royal charter; but the same shall be and remain in full force and vigour as if this Act had never been passed.' See also Williams (in 1880), $\mathrm{n}$ $24, \mathrm{p} 226$.
} 
In conclusion, the law on mines and minerals in the 1844 Act should be repealed and the general law on mines and minerals now prevail.

\section{(f) Conclusion}

Consideration should be given to abolishing any manorial incident (right) to mines and mining. In the past, this was given for necessity. Especially, coal and gravel for roads. Today, there is no such necessity. Rather, any exploitation would be for profit. Thus, the original legal purpose no longer exists. Further, few (if any) manors still exist.

- Thus, it is somewhat dubious whether they can claim any such right. Even if such is not abolished, it is asserted that the same should be limited. Thus, it should not apply to coal, lead, tinor iron. Nor to gravel or sand - save where needed for any private manorial road (which is, likely, to be rare);

- Also, as with sporting rights (see 14(b)), any manorial right to mines and minerals, where registered, should be subject to renewal every 10 years or so. In the past, it was intended that any right should be exercised regularly (especially coal). Not, that it should lie, latent, for decades or more.

It may be noted that, abolishing any manorial right, would not affect the Forest of Dean, where distinct legislation applies to mining. ${ }^{218}$ Finally, to the extent that any manorial right to mines and minerals is retained, the same should be de-linked from holding the same as 'lord of the manor'. Instead, the holding should, now, be qua landholder or in gross (if previously the same).

In conclusion, any local mining customs (such as in respect of coal, tin, lead and iron) should be abolished since they are obsolete. The general law on mines and minerals should now apply-including in the case of the Forest of Dean and the duchy of Cornwall.

Further, consideration should be given to abolishing any Class 3 manorial right to mines and minerals. In most instances, although registered, the same are never exercised which is not the legal purpose for which they were originally upheld (if retained, there should be a requirement of renewal - say, every 10 years). Even if not abolished, such should now be held - not qua lord of the manor - but qua the freeholder of land or in gross. Also excluded should be any right to mine coal, tin, lead or iron - all of which are not now individually mined. Also, possibly, gravel and sand extraction should also be excluded since such was, originally, accorded as a necessity and for manorial (and, in the tenant, only personal) use.

\section{CLASS 3 MANORIAL INCIDENTS - COMMON OF TURBARY}

\section{(a) Introduction}

As noted in the first article, common of turbary (from the medieval latin, turbus or turba, referring to turf or peat) ${ }^{219}$ was the right to dig for peat on manorial land, for fuel. Woolrych noted (in 1850):

The want [lack] of fuel pointed out to them [the manorial tenants] the further necessity of digging up the turves on the waste.... ${ }^{220}$

This class 3 right (see 6(a)(iii)) was given to the tenant who required, as a necessity, peat or coal to heat his house (it had to be an ancient house when claimed by prescription); otherwise he would have frozen. Thus, the right was given for him - whether freeholder or villein - to enable him to perform his agricultural and other due services to his lord in return for his being granted manor land. Today, we would (probably), retrospectively, call this right a form of payment in kind or additional perk of the job.

\section{(b) Abolishing Common of Turbary}

More than a 100 years ago, Elton (writing in 1886) said that this right to turbary had 'entirely fallen into disuse, or is only exercised for unwarranted purposes. ${ }^{221}$ The latter referred to tenants selling peat to others since it was only, legally, a right for their own use and only when the same was necessary in the individual case (also,

\footnotetext{
${ }^{218}$ See n 209.

${ }^{219}$ JH Baxter \& C Johnson, Medieval Latin World-List (OUP, 1955 rep)(turba). HW Woolrych, Treatise of the Law of Rights of Common

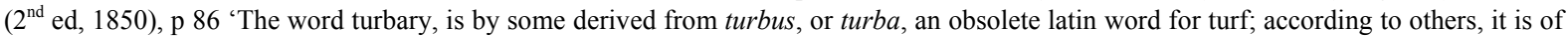
Saxon origin, meaning, either the right of taking turf, or the ground whence the turf is taken. A common of turbary is...a liberty [right] of digging turf upon the ground of another and it may be appendant, appurtenant, or in gross.' See also Williams (in 1880), n 24, p 187 'Common of turbary is a species of estovers, being the right to take peat or turf, which has become by course of time fit for burning, and not green turf, for the purpose of using the same for fuel in a messuage; and, when claimed by prescription, it must be claimed also in respect of an ancient messuage...'.

${ }^{220}$ See McBain, n 1, at fn 25 citing Woolrych, n 219, p 15. Also, Sweet, n 2 (turbary)

${ }^{221}$ Ibid, p 6, n 33.
} 
the quantity taken had to be reasonable). As it is, in Victorian times, coal was cheap. Thus, turbary was, rarely, availed of -peat, also, being less satisfactory than coal as fuel.

- Today, it is asserted that there is no need to retain this legal right (it can held as appendant or appurtenant to land or in gross) since the number of dwellings in the England and Wales without alternative fuel supplies in the form of electricity, gas, oil etc is now miniscule. Thus, it is not necessary;

- Further, burning peat as fuel has environmental and health consequences. And, digging for such damages the land. Finally, the number of persons who avail themselves of any registered right to turbary, in any case, in practice is (likely) to be very small and such will diminish further over the next few years, given the labour involved.

Thus, it is asserted that any common of turbary should be abolished - whether manorial or otherwise. ${ }^{222}$ Or, a date should be fixed for its abolition (say, 2027), to prevent the same being a 'clog' on land titles. Alternatively, if retained, it should be limited to places such as Dartmoor, ${ }^{223}$ the Forest of Dean ${ }^{224}$ the New Forest ${ }^{225}$ and Epping Forest ${ }^{226}$ where the likelihood of any continued need is the greatest. Abolition would not prevent persons acquiring such a right by contract, which is to be encouraged.

In conclusion, common of turbary (including any manorial Class 3 right to turbary) should be abolished, as no longer being a necessity and on environmental grounds. Failing that, it should end by a designated date (say, 2027).

\section{CLASS 3 MANORIAL INCIDENTS -COMMON OF ESTOVERS}

\section{(a) Introduction}

As noted in the first article, common of estovers from the Anglo-Saxon, botes (i.e. repairs, from botettan, to keep in repair or fence) and (likely) the Anglo-Norman fovere, to keep warm or from estover, to store or furnish ${ }^{227}$. was the right of the tenants to take wood on manorial waste land. ${ }^{228}$ Estovers were divided into 3 kinds, viz.

- house bote, to repair the tenant's house. Also, to cut wood for fuel in the house (also, called, fire bote);

- plough bote, where it was needed to repair farm equipment (including a farm cart); and

- hedge bote, where it was needed to repair hedges. ${ }^{229}$

\footnotetext{
${ }^{222}$ As Blackstone noted, n 31, vol 2, p 34 'common of turbary is a liberty of digging turf on another's ground' (italics supplied). Such was not invariably manorial ground. It could be on open moorland or hillside, for example, which was not (or not proved to be) part of a manor. D Walker, The Oxford Companion to Law (1980), (turbary) 'The liberty of digging turf on another's land. It may be created by grant or by prescription and be appurtenant to a house, to take turf as fuel for that house, or in gross.' See also Adkin, n 30, p 168 (freeman of a town might have a right of turbary).

${ }^{223}$ Dartmoor is regulated by the Dartmoor Commons Act 1985 which does not make provision for turbary as such. It may be appropriate to preserve the common right of turbary in Dartmoor, if still availed of and it is a necessity.

${ }^{224}$ For the Forest of Dean Acts, see n 209. These make no mention of turbary. It may be appropriate to preserve the common right of turbary in the Forest of Dean, if still availed of and it is a necessity.

${ }^{225}$ FE Kenchington, The Commoner's New Forest (1942), p 36 referred to the main forest rightsasa those of: (a) turbary (turf fuel), (b) estovers (wood fuel), (c) digging marl [i.e. marlstone, once used to improve the condition of the soil] for dressing the land, (d) bracken for the bedding for animals, (e) rights of common of pasture, including pannage or pawnage (a right for pigs to feed on acorns and the mast of beech trees in woods). However, he also noted, p 47 'The copyhold rights of common, turbary and shooting are of little modern significance'. The New Forest is governed by the New Forest Acts 1877, 1879, 1949, 1964 \& 1970 as well as the New Forests Act 1808. These do not refer to turbary (or estovers) as such. However, there is a register of commons referred to in to the 1877 Act. For the New Forest generally see, also, JR Wise, The New Forest. Its History and Scenery (1862, 1971 rep). It may be noted that the original purpose of the New Forest, from the time of William I (1066-87) was as a deer forest, for royal hunting. For pannage, see Williams, n 24 , p 189.

${ }^{226}$ Epping forest is governed by the Epping Forest Act 1878, see McBain, s 1, n 238. It does not refer to turbary.

${ }^{227} \mathrm{JH}$ Baker, Manual of French Law ( $2^{\text {nd }}$ ed, 1990)(estover). It may also (more likely) have come from estevoir or estovoir, meaning that which is necessary, see $\mathrm{n} 228$.

${ }^{228}$ Sweet, $\mathrm{n} 2$ (in 1882) (estovers) 'Every tenant for life or years of freehold land, unless restrained by agreement, may of common right take upon the land a reasonable quantity of wood for fuel, repairs etc. This is called estovers or botes, which are sometimes divided into housebote, for fuel and repairs of the house, plough-bote for making and repairing instruments of husbandry, and hay-bote for repairing fences (anglo-saxon, hegge; norman French, haye, a hedge or enclosure). Copyholders' rights of estovers are sometimes subject to customary restrictions.... (from the old french, estevoir or estovoir, that which is necessary).Walker, n 222 (estover) 'Any kind of sustenance, particularly wood, a reasonable amount of which any tenant for years or for life of freehold may by common right take from the land for fuel or repairs.'

${ }^{229}$ There was also cart bote, which was taking wood to repair a tenant's cart, now (effectively) obsolete or treated as part of plough bote. See Woolrych, n 219 (in 1850), pp 14-5 'It was natural that...tenants should build a house on their newly acquired lands; that they should raise a fence for the protection of their property, or for a boundary; that they should cultivate their ground for the maintenance of their
} 
Besides wood, house bote (of which fire bote was a division) could include other sources of fuel such as ferns etc. ${ }^{230}$ The right to estovers (like turbary) was to enable the tenant (freehold or copyhold) to perform his service obligations to the lord (ad manutenendum servicium socae, in the case of the freeholder). It was also accorded on the basis of necessity, had to be in reasonable quantities and it could not be on-sold. Further, the tenant had to cut himself.

\section{(b) Abolishing Common of Estovers}

The grounds for abolishing estovers generally - including in any class 3 manorial context - are the same as for turbury above. Such rights to wood are no longer necessary for fuel. Nor for the repair of a tenant's house or farm equipment. Nor, for the repair of hedges where, today, there is no more inclosure of common fields ${ }^{231}$ and fencing is often effected by means of barbed wire or comprises purchased pre-cut, treated, wooden posts etc. Further, although such a right is registered, it is asserted that, in practice, it is (increasingly) little availed of.

Alternatively, if this right is not abolished, it should be limited only to places such as Dartmoor, Forest of Dean, the New Forest and Epping Forest where the likelihood of any continued need is the greatest. Further, it should be subject to renewal (say, every 10 years) to prevent land titles being 'clogged'. Abolition would not prevent persons acquiring such a right by contract, which is to be encouraged.

\section{In conclusion, common of estovers (including any manorial Class 3 right to estovers) should be abolished, as no longer being a necessity and on environmental grounds(re using ferns to burn etc). Failing that, it should end by a designated date (say, 2027).}

\section{CLASS 3 MANORIAL INCIDENTS - COMMON OF PISCARY}

Common of piscary (fishery, from the latin, piscis, a fish) was, and is, the class 3 right of the tenant to fish in ponds and streams on manorial waste land. ${ }^{232}$ Again, like the right to turbary and to estovers (see above), it was a perk to enable the tenant, whether freehold or copyhold, to perform his obligations. It was one of necessity (for the tenant to feed himself and his family) not one of pastime (to fish for pleasure). ${ }^{233}$ It could be held as a right appendant, appurtenant or in gross. Williams (in 1880) stated:

Common of piscary is a liberty of fishing in another man's water, in common with the owner of the soil and perhaps also with others, who may be entitled to the same right. It does not very often occur...common of piscary may, like other common rights, be either appurtenant to a house; in which case it would seem that the fish taken ought to be consumed in the house, to which right it is

families. Hence....arose common of estovers. House bote was allowed to these tenants for rearing and sustaining their habitations, and for fuel to be burnt therein; hay or hedge bote for setting and keeping up their fences and inclosures; plough-bote and cart bote for making and repairing their instruments of tillage.' Blackstone, n 31, (in 1766), vol 2, p 35 'These several species of commons do all originally result from the same necessity as common of pasture; viz. for the maintenance and carrying on of husbandry: common of piscary being given for the sustenance of the tenant's family; common of turbary and fire bote for his fuel; and house-bote, plough-bote, cart-bote, and hedge-bote, for repairing his house, his instruments of tillage, and the necessary fences of his grounds.'

${ }^{230}$ Williams, n 24 (in 1880), p 199 referred to 'wood, turf, furze [i.e. gorse], fern etc'. Ibid, p 18 'rights of cutting timber, underwood, gorse or furze, and such like, for fuel to burn in the house [it had to be an ancient house, in the case where the claim was by way of prescription], called fire bote...'. See also Ibid, p 186 'no such user can possibly take place except in an ancient house.' For taking thorns to burn, see Ibid, pp 20, 202.

${ }^{231}$ See McBain, n 1. The last inclosure was 1914 (or, possibly, 1901). When inclosure was made, fencing was required to separate common fields into individually farmed fields.

${ }^{232}$ This right of fishing must be distinguished from a: (a) royal fishery; (b) public (or common) fishery. The first is an exclusive right of the Crown to fish in a public river (if granted to a subject it is called a free fishery). The second (also, called a public common of fishery) is the right of the public to fish in the sea and in public navigable rivers as far as the tide flows. Contrariwise, common of piscary is a private right of fishing which should also be distinguished from two other private rights, a: (c) several fishery; (d) free fishery, The first is an exclusive right of fishing in a particular water, and vested either in the owner of the soil or in someone claiming under him. The second is (according to Blackstone) the exclusive right of fishing in a public river. Sweet, $\mathrm{n} 2$ (in 1882) (common of piscary) 'common of piscary or fishery is the right of fishing in another man's waters, such as a pond or private river, but in common with, that is, not in exclusion of, the owner of the soil. Common of piscary is a profit a prendre, and may be either appurtenant or in gross, but apparently not appendant. The term seems to be confined to the right of fishing which the tenants of manorial land have in fishing in the waters of the lord.' One would agree that 'common of piscary' only applied, originally, to a manorial right to fish.

${ }^{233}$ Woolrych, n 219 (in 1850), p 15 'Common of piscary supplied the wants of their [the free and copyhold tenants'] tables, being given for the sustenance of their families'. Also, pp 89-91 'Common of fishery is a right which one may have in common with others, to take fish in the water of a third person and like other commons, it may be appendant, appurtenant, or in gross. The commencement of this right arose like other commonable privileges from the tenant's necessities; as estovers were given him for turves for his fuel, so fish were allowed him for the sustenance of his family... the taking must be reasonable... A piscary can only exist in rivers for the sea, and all navigable rivers, are open to all the king's subjects....It has been said, that the original grant of this privilege was for the tenant's family, and it seems, that the most proper mode of using it is to confine the consumption of fish to the commoner's table.' Blackstone, n 31, (in 1766), vol 2, p 35 'Common of piscary is a liberty of fishing in another man's waters...these several species of commons do all originally result from the same necessity as common of pasture; viz. for the maintenance and carrying on of husbandry...'. See also Williams, n 24, pp 259-70. 
appurtenant; or it may be claimed as a right in gross, and not attached to any tenement. And it may arise either by grant or prescription. The incidents of common of piscary appear to be in every respect analogous to those of common of estovers, turbary and the like. ${ }^{234}$

The amount taken had to be reasonable and was a personal right. It could not be on-sold. Today, even if registered, this right is rarely availed of and it is not a necessity. Nor given to effect a service obligation. For the same reasons as given in respect of turbary and estovers, it should be abolished or end by a designated date (say, 2027). It should be noted that, abolishing common of piscary, will not affect royal or public (common) fishery rights - which are fishing rights of the Crown or the general public. Nor other private rights of fishing, such as a right of several fishery (the right to fish in a particular water) or a right of free fishery (the exclusive right to fish in a public river). To avoid any confusion as to what is being abolished, however, specific reference could be made to the abolition of common of piscary in the manorial context, if necessary (see Appendix A).

In conclusion, the Class 3 right to common of piscary should be abolished. Failing that, it should end by a designated date (say, 2027).

\section{CLASS 3 MANORIALINCIDENTS - COMMON OF PASTURE}

Common of pasture was an important right in medieval times. Manorial tenants (whether freehold or copyhold) had to provide agricultural services using their oxen, horses etc. Thus, they needed somewhere on the manor to graze them. Also, they needed to graze their cattle, sheep, pigs etc. to sustain themselves. Having little ground to do this, they were accorded the right by the lord of the manor to graze their animals on manorial waste or, in uninclosed land, the free tenants allocated among themselves land for such purposes. ${ }^{235}$ Hence, in law, in time there was upheld a right to common of pasture and this could be a right that was appendant, appurtenant, in gross or in vicinage. However, the inclosure of land meant fewer tenants who exercised rights of common. Also, pasturing animals in common, often, increased the risk of disease spreading among them and made it less popular. Further, oxen gave way to horses and tenants tended to end up with just horses, cattle and sheep - given the value of the same. Scrutton wrote in 1887:

in the present days of high farming and careful breeding good cattle are not fed on the commons; the rights of common are but little used; and 'sufficiency of pasture', which is estimated by recent user, is a fast diminishing quantity. ${ }^{236}$

The number of persons availing themselves of rights of pasture has continued to decline today and registration of such rights is required by the Land Registration Act 2002 which Act made irrelevant precise distinctions as to common of pasture appendant and that of in vicinage. ${ }^{237}$

Since common of pasture still has some importance any class 3 manorial right should be de-linked from being a manorial right and become one held by a land owner or in gross. Further, any registered right should be subject to renewal every 10 years, to prevent such a right clogging the land title when, in fact, it is never exercised and, thus, it is obsolete (spent) in practice.

\section{CLASS 3 MANORIAL INCIDENTS - OBLIGATION re BRIDGES, SEA WALLS}

\section{(a) Introduction}

In Anglo-Saxon times, the Crown imposed three military duties on all men of England. It was known as the trinoda necessitas (the threefold obligation). These comprised: (a) attendance on the local militia (the fyrd); (b) the making of roads; and (c) the repairing of bridges and defensive fortifications. In the case of bridges, the Crown imposed a toll or tax (called bridtol) on those who used the bridge, to finance its continued maintenance and repair. ${ }^{238}$

- After, the Norman Conquest 1066, the toll became known as pontage (pontagium). The Crown also began to franchise the right to impose such a toll, as the network of bridges (and roads) expanded. The first grant of a franchise may have been in 1228 (for Ferrybridge, near York) ${ }^{239}$ Lords of the manor, often, sought such grants. However, such franchises of the Crown prerogative ended by the $15^{\text {th }}$ century

\footnotetext{
${ }^{234}$ Williams (in 1880), n 24, p 259. He distinguished common of piscary from a several fishery which, also, could be appurtenant to a manor. Ibid, p 264. See also Adkin (1911), n 30, pp 168-9.

${ }^{235}$ See generally, McBain, n 1, pp 34-5.

${ }^{236} \mathrm{Ibid}, \mathrm{p} 35, \mathrm{n} 32$

${ }^{237} \mathrm{Ibid}, \mathrm{n} 32$.

${ }^{238}$ See generally, McBain, n 14(c), pp 71-4.

${ }^{239}$ Ibid, p 72.
} 
${ }^{240}$ and the Crown was (often) too generous in granting exemptions to paying pontage (for example, all London citizens were exempt from paying all tolls throughout England and the sea ports). ${ }^{241}$

- There was uncertainty, too, as to who was legally obliged to maintain bridges. The result was that many bridges fell into dis-repair. Legislation was, therefore, enacted - the Statute of Bridges Act 1530. It provided that, if no one was found responsible for the upkeep of a bridge, the local justices of the peace had authority to tax every inhabitant of the relevant borough, shire etc. such sum they determined was reasonable for 'repairing, re-edifying and amendment of such bridges ${ }^{242}$ Other legislation relating to bridges -and their repair and maintenance -followed. ${ }^{243}$ For the Crown prerogative in respect of pontage, see 17.

In the case of defensive walls (including sea walls), these comprised defensive (military) fortifications and part of the trinoda necessitas. The relevant toll was called burhbot by the Anglo-Saxons and murage by the Normans. It, also, was franchised. The first grant being said to have been to the town of Shrewsbury in 1218 and the last in the $15^{\text {th }}$ or $16^{\text {th }}$ century when the nature of warfare changed and large defensive walls around London and fortified towns (burghs) were no longer required. ${ }^{244}$

\section{(b) Present Position}

The obligation of lords of the manor (or, less so, on a tenant) to maintain bridges and sea walls, as well as roads, was progressively reduced as the State took over more and more of these responsibilities by virtue of legislation and the road network developed. Also, with the process of inclosure, private, local and general legislation made provision on such matters (awards of the inclosure commissioners) and many bridges, ditches and dykes etc were altered, removed or filled in as the landscape changed. So too, in the case of sea walls. Thus, such an obligation fell into obsolesence in many cases. Also, general legal texts such as Woolrych, The Law of Rights of Common (second edition in 1850) and Williams, Rights of Common and Other Prescriptive Rights (in 1880) scarcely dealt with such. ${ }^{245}$

Today, as noted in 6(a)(iiii), the class 3 obligation of a lord of a manor (or a tenant) to maintain a seawall, bridge, dyke, ditch etc is subject to registration under the Land Registration Act 2002. It is asserted that - if the legal concept of a manor is abolished - this obligation should, also, be abolished. In practice, even in the case of registered rights it is, anyway, unlikely to apply in practice since local councils and the State, generally, have responsibility for all bridges used by the public as well as all sea walls (the location of which has, also, often changed). Alternatively, the obligation can be de-linked from his being a lord of the manor (or a tenant) and be applied to him qua land holder instead (these obligations would not appear to apply in gross).

In conclusion, any obligation of a lord of the manor to maintain a bridge, sea wall, ditch, dyke or the like etc should be abolished.

\section{ABOLISHING VARIOUS CROWN PREROGATIVES}

The Crown has certain prerogatives. That is, privileges or rights. ${ }^{246}$ Some of these, in early times, were granted to some lords of the manor pursuant to a charter (carta, writing). These franchises (a grant of a Crown prerogative) - which were, often, costly to acquire - are not manorial, but franchisal. They were also granted to important knights, clerics, abbeys, towns etc. Crown privileges commonly granted to lords of the manor were those of:

- waif;

- estray;

- royal fish;

- treasure trove;

- royal swans;

\footnotetext{
${ }^{240}$ Possibly, the last was c.1468, see Ibid, p 72, n 53.

${ }^{241}$ Ibid, $\mathrm{p} 73$.

${ }^{242}$ Ibid, p 74. There were also many local and private Acts dealing with specific bridges that imposed a charge on users for the repair, or maintenance, of the bridge.

${ }^{243}$ See also McBain, $\mathrm{n}$ 14(g), pp 44-5. In early Victorian times, for indictments for public nuisance (a criminal offence) for failure to repair a bridge, see Ibid, p 63 (Chitty, 1826). FromVictorian times there was a raft of legislation dealing with bridges, highways etc.

${ }^{244}$ McBain, n 14(c), pp 74-6.

${ }^{245}$ See e.g. Williams, n 24, pp 363-4 who, generally, cites Coke and some old cases.

${ }^{246}$ A useful work, summarising the Crown prerogatives in the Victorian era, is J Chitty Jr, A Treatise of the Law of the Prerogatives of the Crown (1820).
} 
- wreck.

If the tenurial system is abolished and/or if manors are abolished, the abolition of these franchises should also occur since they are now all obsolete in practice (save in respect of swans on the Thames). As to the first three of the above, they should be wholly abolished as Crown prerogatives (including any franchise), being obsolete and not required in any case.

\section{(a) Waif}

The Crown used to have the prerogative (right) to things cast away by a thief in flight (called 'waif') and - some what bizarrely - it continues to do so since this Crown prerogative has never been abolished. ${ }^{247}$ Thus, any franchise of the same is still extant. ${ }^{248}$ However, such a right is long obsolete. Halsbury states:

Waifs are things stolen and thrown away by the thief in his flight; and they belong to the Crown by prerogative right, as a punishment, it is said, to the owner for not having pursued the thief and retaken the goods. ${ }^{249}$

However, caselaw limited this right considerably. Thus:

- Right to Re-Take Stolen Goods. The stolen goods do not belong to the Crown until they have been seized on its behalf. Thus, property remains in the original owner if he can re-take the stolen goods before they have been so seized;

- Fresh Suit. Even when in the hands of the Crown, the owner is entitled to restitution if he pursues the thief with due diligence (this is called 'fresh suit'). Also, if the owner brings the thief to justice and secures a conviction;

- Goods Hidden or Left. If the stolen goods are hidden (or left behind) by the thief, they are not waifs and the property remains in the owner;

- Foreign Merchant. If the stolen goods belong to a 'foreign' merchant they are not waifs. ${ }^{250}$

It has been asserted that this Crown prerogative should be abolished. ${ }^{251}$ This would abolish any franchise as well.

- This prerogative derives from when a thief fled on foot (or horseback) and was pursued by hue and cry. Today, even if thieves throw away goods in flight (such as goods thrown from a car) they are, invariably, found and can be identified by the police - and returned to their owner. Thus, waif does not arise, in practice;

- Further, neither the Crown - nor any franchisee - asserts such a right in modern times and the case law is very old (the latest case may be Foxley (1600));

- Also, this right arose from the legal obligation to make 'hue and cry'. That is, of the victim to cry out that he had been robbed and, with others, to pursue the thief and apprehend him. However, hue and cry is also long obsolete and - since the early $19^{\text {th }}$ century - there has been a police force charged with the pursuit, and apprehension, of thieves. Indeed, the law does not (generally) encourage ordinary citizens to 'take the law into their own hands' and seize a thief because of the dangers of injury (or mistaken identity).

If the prerogative of waif was abolished, then, the ownership of goods thrown aside by a thief would remain with the owner - the same as when a thief hides (or leaves behind) another's goods. There is no need to distinguish the two.

\footnotetext{
${ }^{247}$ For an analysis of this see McBain, n 14(c), p 77. Blackstone, n 31, vol 1, p 297 'Waifs, bona waviata, are goods stolen and waived or thrown away by the thief in his flight, for fear of being apprehended. These are given to the king by the law as a punishment upon the owner, for not himself pursuing the felon and taking away his goods from him.' See also Williams (in 1880), n 24, pp 281-2.

${ }^{248}$ Williams, n 24, p 281 'Waifs are another prescriptive right, often belonging to lords of manors by grant from the Crown, or by prescription.'

${ }^{249}$ Halsbury Laws, n 62 (4 $4^{\text {th }}$ ed, 1994), vol 12(1), para 371. Halsbury referred to Foxley's Case (1600) 5 Co Rep 109a (77 ER 224) 'And the reason that waif is given to the king, and that the party shall lose his property in such case is, for default in the owner that he doth [does] not make fresh suit to apprehend the felon.' Sweet, n 2 (fresh suit) 'If a person is robbed of goods, and makes fresh suit, that is, immediately follows and apprehends the thief, he shall have his goods again, notwithstanding the thief may have thrown them away, so that if were not for the fresh suit they would become waifs.'

${ }^{250}$ McBain, n 14(c), pp 77-8.

${ }^{251}$ Jessel, n 2, p 261 'Waifs were stolen goods dropped or 'waived' by a thief in flight. The Crown claimed them even where the true owner was known. This was an inducement to bring the thief to justice, because on conviction the owner could reclaim them. Waifs were generally granted to lords of the manor and are now obsolete.'
} 
In conclusion, this Crown prerogative should be abolished, being obsolete. It would be of no loss to the Crown or to any lord of the manor (or other franchisee), in practice.

\section{(b) Estray}

Halsbury notes that:

Estrays [strays] are valuable animals of a tame or reclaimable nature which are found wandering in any manor or lordship, and whose owner is unknown. They belong to the monarch as general owner and lord paramount by way of recompense for the damage done, and to preserve the animal alive, unless, as is more generally the case today, they belong to the lord of the manor by grant or prescription. ${ }^{252}$

In olden times, farming was (generally) on an open field system in which the fields were not inclosed (fenced) and there was a lot of manorial waste as well as a lack of definition between the land of one person and that of another. Estrays did not include wild animals (apart from swans). ${ }^{253}$ Nor pets. Nor animals of the sovereign. Today, the potential for farm animals becoming estrays is very limited since such animals (such as horses, pigs and sheep) are marked and land is inclosed. Also, there are (very) few manors left. Further, there are limitations to asserting a right of estray, viz.

- $\quad$ Ownership. The absolute property in the estray does not vest in the Crown (or lord of the manor, as franchisee) until the holding of an estray has been proclaimed in the church and the two market towns next adjoining the place where it has been found and nobody has claimed it within a year and a day. After such, they will belong to the sovereign (or lord of the manor). Before that period the sovereign (or lord of the manor) has property in the estray against all but the rightful owner;

- $\quad$ Feed \& Preserve Estray. The sovereign (or franchisee) is obliged to feed (and preserve) any estray from damage during the year and a day period. Further, the franchisee is liable to be sued if he uses the animal for the purpose of labour. For its part, if the rightful owner claims the wandering animal within a year and a day it must pay the reasonable costs of feeding, keeping and proclaiming the same.

It is asserted this Crown prerogative should be abolished. It is simply unnecessary - since identification of stray farm animals is now most unlikely - and the case law is very old (the last case cited by Halsbury is in 1785). Further, the desire of the Crown (or any franchisee) to keep estrays of little worth for a year and a day must be minimal in modern times. Not least, because the same must bear all the costs of feeding and maintenance (further, the franchisee cannot use the animal). Today, strays would likely be (soon) handed over to the police or the RSPCA. Finally, a lord of the manor would have to prove that they have a Crown grant of such a franchise such a thing being unlikely in most cases and not worth the effort.

If the law on strays were abolished, the ownership of a tame animal wandering into the lordship of another would remain with the original owner - subject to the right of the finder in respect of abandoned animals under the law of bailment. Thus, the general law will apply.

In conclusion, this Crown prerogative should be abolished, being obsolete. It would be of no loss to the Crown or to any lord of the manor (or other franchisee), in practice.

\section{(c) $\underline{\text { Royal Fish }}^{254}$}

The Statute of Prerogativa Regis (still extant) is of uncertain date. Halsbury thought that it was c. 1324 although it may be earlier (c. 1273-4). ${ }^{255}$ Chapter 13 (translated from the latin) states:

\footnotetext{
${ }^{252}$ Sweet, n 2 (estrays) 'Estrays are such valuable animals as are found wandering in any manor or lordship, and no man knoweth the owner of them; after they have been proclaimed and kept for a year and a day without the owner appearing, the law gives them to theCrown; in most cases, however, they belong to the lord of the manor by special grant from the Crown.' See also McBain, n 14(c), pp 78-80.

${ }^{253}$ Blackstone, n 31, vol 1, p 288 'Any beast may be an estray, that is by nature tame or reclaimable, and in which there is valuable property as sheep, oxen, swine, and horses, which we in general call cattle...For animals upon which the law sets no value, as a dog or cat, and animals ferae naturae, as a bear or a wolf, cannot be considered strays. So swans may be strays, but not any other fowl; whence they are said to be royal fowl. The reason for which distinction seems to be be, that, cattle and swans, being of a reclaimable nature, the owner's property in them is not lost merely by their temporary escape; and they also, from their instrinsic value, are a sufficient pledge for the expense of the lord of the franchise in keeping them a year and a day.' See also Williams, n 24, p 286 'An estray is an animal of value, tame and reclaimable, such as an horse, an ox, a sheep, or a pig.'

${ }^{254}$ See generally, McBain, n 14(c), pp 80-3. Also, McBain, n 14(d), p 24, n 147. Jessel, n 2, pp 265-6, stated 'In theory the royal right to swans and royal fish (whales, sturgeon and grampuses [likely, a reference to porpoises]) could be granted as franchises, but they are unknown, although some subjects have limited rights to swans.' However, this is incorrect. Such franchises were granted. See also Williams (in 1880), n 24, pp 292-3.

${ }^{255}$ See generally, McBain, n 14(c), p 548.
} 
the king shall have ...throughout the realm, whales and great sturgeons taken in the sea or elsewhere within the realm, except in certain places privileged by the king. ${ }^{256}$

Such a Crown prerogative existed, at least, in the $12^{\text {th }}$ century. It may have derived from Danish or Norman law. The privilege was (likely) because whales and sturgeon were a delicacy. The right of the Crown may only have extended to the shore (or near the coast) and not on the high seas. Further, the Crown prerogative did not apply to certain privileged places such as Durham, Lancaster and, possibly, the principality of Wales. This prerogative was, sometimes, franchised by way of a grant to others or it arose by prescription (which pre-supposes a prior grant). The former (the grant) could be appurtenant to a manor (or a hundred or an honour) or in gross. ${ }^{257}$ The right of the Crown to royal fish was expressly preserved by the Wild Creatures and Forest Law Act 1971, s 1 of which abolished:

any prerogative right of her Majesty to wild creatures (except royal fish and swans), together with any prerogative right to set aside land or water for the breeding, support or taking of wild creatures. (italics supplied)

The Crown (the sovereign) in 1971 made it clear that she no longer wished to avail herself of this prerogative and, in any case, the catching of whales in the seas around England is prohibited. ${ }^{258}$ Also, all types of whales (cetacean) and sturgeon (acpensar sturio) comprise European protected species. As such, their capture, killing, disturbance, keeping, transport, sale or exchange is prohibited. ${ }^{259}$ Finally, there is no evidence of any lord of the manor (or any franchisee) seeking to assert a franchise in respect of royal fishing in modern times. ${ }^{260}$

\section{In conclusion, this Crown prerogative should be abolished.}

\section{(d) Treasure Trove}

In the distant past, the Crown (sometimes) franchised treasure trove - including to some lords of the manor. However, such was rare. ${ }^{261}$ The Treasure Act 1996 placed the law on treasure trove in statutory form, although it did not abolish the Crown prerogative as such. ${ }^{262}$ The Act, s 4 (ownership of treasure which is found) provides, in particular, as follows:

(1) When treasure is found, it vests, subject to prior interests and rights - (a) in the franchisee, if there is one; (b) otherwise, in the Crown.

(3) If the treasure would have been treasure trove if found before the commencement of this section, neither the Crown nor any franchisee has any interest in it or right over it except in accordance with this Act. ${ }^{263}$

Mention is made of franchisees in s 5 (meaning of franchisee):

\footnotetext{
${ }^{256}$ Ibid.

${ }^{257}$ Ibid, p 549.

${ }^{258}$ Whaling Industry (Regulation) Act 1934, ss 2-3.

${ }^{259}$ Conservation (Natural Habitats etc) Regulations SI 1994/2716 (as amended), reg 39(1).

${ }^{260}$ See generally, McBain 14(c), pp 80-3 and McBain, n 14(d), p 24.

${ }^{261}$ See 14(d). Williams (in 1880), n 24, p 2801'Treasure trove is another franchise often claimed by lords of manors by grant from the Crown or by prescription....Nothing but gold and silver comes within the description of treasure trove.'See also Jessel, $\mathrm{n} 2$, $\mathrm{p} 263$ 'In theory both royal mines and treasure trove could be granted as franchises. In fact they are rare...'.

${ }^{262}$ Halsbury Laws, n 62, vol 77, para 1088 'The common law doctrine of treasure trove...has been replaced by a new regime under the Treasure Act 1996...'Cf. Jessel, n 2, p 272 'It [the Treasure Act 1996] abolishes the old franchise of treasure trove and in its place creates a new greater franchise of treasure (though this is statutory rather than out of the royal prerogative) which includes everything that used to be treasure trove and a good deal more...Any holder of the former franchise is given the new one in exchange.' This would not appear to be well put since there was no abolition as such

${ }^{263}$ Section 4(2) \& (4) states: '(2) Prior interests and rights are any which, or which derive from any which - (a) were held when the treasure was left where it was found, or (b) If the treasure had been moved before being found, were held when it was left where it was before being moved. (4) This section applies - (a) whatever the nature of the place where the treasure was found, and (b) whatever the circumstances in which it was left (including being lost or being left with no intention of recovery).'
} 
(1)The franchisee for any treasure is the person who - (a) was, immediately before the commencement of section 4, or (b) apart from this Act, as successor in title, would have been, the franchisee of the Crown in right of treasure trove for the place where the treasure was found.

(2) It is as franchisees in right of treasure trove that Her Majesty and the Duke of Cornwall are to be treated as having enjoyed the rights to treasure trove which belonged respectively to the Duchy of Lancaster and the Duchy of Cornwall immediately before the commencement of section 4.

Given that the Treasure Act 1996 was (clearly) intended to supercede any Crown prerogative (and any franchise, none of which grants have been made in recent times) it is asserted that the Crown prerogative to treasure trove should be abolished. Also, any franchise. As it is, the only persons who would seem to have a franchise besides the duchies of Cornwall and Lancaster - are (possibly) the City of London (grant of 1638, "treasure found in the same city, or the liberty of the same') and the town of Bristol (grant of 1461, 'thesarum inventum '). ${ }^{264}$ However, the first would only cover the Square Mile now and the latter would be limited to the ambits of the town in 1461. And, both would only apply to treasure trove as covered by the Treasure Act 1996. Further, it is unclear the extent to which the City of London and the town of Bristol have ever asserted such rights.

As well as the Crown prerogative to treasure trove, the Crown has a prerogative to dig on the land of another for treasure trove. ${ }^{265}$ This, also, should be abolished, as an unnecessary intrusion on private ownership. In any case, it has (likely) been (very) rarely availed of down the centuries.

\section{In conclusion, this Crown prerogative should be abolished.}

\section{VARIOUS CROWN PREROGATIVES - FRANCHISE}

While the Crown prerogatives of waifs, estray and royal fish should be abolished entirely - being obsolete - any franchise of the Crown prerogative to royal swans - should, today, be limited to certain long-standing franchisees. And, any franchise of wreck should be abolished (indeed, it, often, is onerous rather than being a benefit). Such franchises were, in the past, sometimes, granted to lords of the manor. As to these:

\section{(a) Royal Swans ${ }^{266}$}

The Crown is entitled to white swans as volitalia regalia (royal fowl) if they are:

- wild;

- unmarked; and

- $\quad$ swimming in open and common rivers. ${ }^{267}$

This prerogative has existed, at least, since 1186. The reason for such was that young swans were a choice food reserved for the sovereign at feasts and banquets. This Crown prerogative to swans did not prevent subjects from having the right to unmarked swans on their own lands. However, if these escaped - and were found in open and common (public) rivers - the king's officer could seize them.

In early times, the Crown franchised this prerogative to, inter alia, lords of the manor in respect of certain parts of the country. ${ }^{268}$ Today, the Crown only exercises this Crown prerogative in respect of certain stretches of the Thames and its surrounding tributaries. ${ }^{269}$ Also, the swans are not eaten. The only present franchisees of this Crown prerogative are the:

- Worshipful Company of the Vintners;

\footnotetext{
${ }^{264}$ See 14(d), pp 20-2 (including reference to the duchies).

${ }^{265}$ See McBain, n 14(d), pp22-3.

${ }^{266}$ See generally, McBain, n 14(c), pp 80-3. Halsbury Laws, n 62, vol 29, para 144 'Provided they are wild and unmarked, the property in all white swans swimming in open and common rivers belongs to the Crown by prerogative right.'

${ }^{267}$ This was confirmed in the Case of the Swans (1592) 7 Co Rep 15b at 16a 'all white swans not marked, which having gained their natural liberty, and are swimming in an open and common river, might be seized to the king's use by his prerogative .....as a swan is a royal fowl; and all those, the property whereof is not known, do belong to the king by his prerogative.' Ibid, 17a, 'none can have [i.e. put] a swan mark...unless it be by grant of the king, or of his officers authorised thereto, or by prescription. And if he hath [has put] a lawful swan mark, and hath [has] swans swimming in open and common rivers lawfully marked therewith, they belong to him ratione privilegia...and he who hath [has] such swan mark may grant it over.'

${ }^{268}$ See McBain, n 14(c), p 82, fn 120, a grant in 1357 to one CW for 7 of all wild signets unmarked between Oxford and London. Also, a grant in 1393 of all wild swans unmarked in the county of Cambridge.

${ }^{269}$ Today, the swans are not marked but ringed and this is practised by the Crown's master of swans annually (in July) on a stretch of the Thames from Sunbury to Abingdon (a distance of 79 miles). 'Upping' refers to their being taken from the water.
} 
- Worshipful Company of the Dyers ${ }^{270}$

- Illchester family. ${ }^{271}$

None of the above are franchisees in a manorial capacity. It would seem appropriate to now restrict this Crown prerogative to the river Thames. One imagines the Crown would have no problem with such. Also, to confirm that any franchise - apart from those mentioned - is abolished.

\section{In conclusion, this Crown prerogative should be limited to the river Thames and to certain designated franchisees.}

\section{(b) $\underline{\text { Wreck }}^{272}$}

The Crown prerogative to wreck was, in early times, sometimes franchised (as well as that to flotsam, jetsam, ligan and derelict) ${ }^{273}$ since it could be valuable given the large amount of shipwrecks along the English coast. Sometimes, the franchisee was a lord of the manor. ${ }^{274}$ However, today, wrecks are few and this Crown prerogative is not availed of by any franchisee, since the same is (invariably) worthless, given modern shipping. ${ }^{275}$

\section{In conclusion, any franchise of this Crown prerogative should be abolished.}

\section{ABOLISHING MORE CROWN PREROGATIVES -ROADS, BRIDGES\&FERRIES etc}

Jessel - in his text on the Law of the Manor (1998) ${ }^{276}$ - mentioned other Crown prerogatives (with the right to toll, this being a distinct grant) which a person (including the lord of a manor) in times past may have acquired a franchise of. He stated: 'most ancient tolls are long gone but enough traces remain to call for an explanation ${ }^{277}$ In respect of these, the following may be noted:

- Castles \&Defensive Walls - Murage. For obvious reasons, from early times, the Crown reserved to itself the right (the prerogative) to build castles or fortified houses (forts) for the purpose of defence. This prerogative to castellate (and any franchise) still prevails - although it should be abolished as unnecessary ${ }^{278}$ The Crown also franchised the right to maintain, and repair, castle walls - as well as defensive walls, such as City and town walls - together with the right to levy a toll (a tax) called murage. The latter was levied on travellers and carts entering the castle, City or town. Such a franchise

\footnotetext{
${ }^{270}$ The grant to the Dyers was given in 1473 and that to the Vintners c. 1483. See McBain, n 14(c), p 82.

${ }^{271}$ This swannery (swan breeding colony) was established by monks who built the monastery at Abbotsbury (which was not on a manorial estate) during the 1040's (it was dissolved in 1539). Its purpose was to farm swans for banquets. The franchise passed to the Ilchester family who own the breeding colony today.

${ }^{272}$ See generally, McBain, n 14(e), pp 306-12. Also, Williams (in 1880), n 24, pp 289-90.

${ }^{273}$ Jessel, n 2, pp 264-5 'There are four varieties [of wreck]. Flotsam is where a ship is split, and the goods being carried, float onto the foreshore. Jetsam is where a ship is in danger of sinking and the goods are thrown out into the sea to lighten it. Ligan, lagan or ligam is where goods are deliberately thrown into the sea with a buoy marking the spot, so that they are not abandoned, but if the owner does not come and claim them...they are wreck. Derelict is where a ship comes to land or sinks. Franchises of wreck normally comprise only jetsam, flotsam and ligan but the jurisdiction of the receiver of wreck under s 255 of the Merchant Shipping Act 1995 extends to derelict, and, in practice, particularly where a ship broke up, the tenants of a coastal manor would often take and keep the timbers for themselves. Wreck was often granted to lords of coastal manors...'. (italics supplied). See also Williams (in 1880), n 24, p 290 and Blackstone, n 31, vol 1, p 292.

${ }^{274}$ Ibid, p 265 'The Act of 1995 [Merchant Shipping Act1995] replaced the Merchant Shipping Act 1894 which made express provision for the right of lords, as under s 254 notice of the finding of a wreck had to be given to a lord who had the franchise and under s 525 and 526 he had an opportunity to claim it. Following changes made under the Merchant Shipping (Registration etc) Act 1993 the legislation no longer refers to lords of the manor but their rights are not affected. However, nowadays a wreck is more often a nuisance to be cleared up than a profitable advantage, and local authorities who want unsightly rubbish removed from a beach may try to pin responsibility onto a lord who has the wreck.' Williams (in 1880), n 24, p 291 'The right to wreck of the sea was in ancient times frequently granted by the Crown to lords of manors and other persons; and it may be claimed by a subject either by express grant or by prescription.'

${ }^{275}$ McBain, n 14(e), p312, n 234 citing NE Palmer, Interest in Goods (2 ${ }^{\text {nd }}$ ed, 1998) 'The system of reporting and disposal [of wreck] has infact largely fallen into disuse. For example, just 25 items of wreck were reported in 1990, of which 21 had no value and were disposed of immediately by the receiver. The four other cases involved a small pleasure craft broken free from its moorings, a marine engine, a coil of rope and one item from a historic wreck.'

${ }^{276}$ Jessel, n 2, ch 15.

${ }^{277}$ Ibid.

${ }^{278}$ See McBain, n 14(g), pp 34-8. Jessel, n 2, pp 259-60 stated 'After the chaotic times of king Stephen [1135-54], castles could only be built under a royal licence [i.e. franchise] to castellate and most defended houses needed such authority. In the fifteenth century, many moated manor houses were built, but if defended they needed a franchise. These rights of defence are now obsolete, anyone who wished to erect a castle nowadays would need planning consent, but in any case, since the use of gunpowder became widespread, such fortresses have little value.' Coke, n 30, vol 1, 5a 'no subject can build a castle or house of strength imbattled, etc, or other fortress defensible...without the licence of the king, for the danger which might ensue, if every man at his pleasure might do it.'
} 
was (often) availed of by towns which had large defensive walls around them, see also $\mathbf{2 0}{ }^{279}$ Lords of the manor with towns on their land, also, availed themselves of the franchise - especially before town corporations began to exist. ${ }^{280}$ The Crown prerogative to levy murage is long obsolete. It ended by the $15^{\text {th }}$ century at the latest when castles and defensive City and town walls became obsolete with the changing nature of warfare. It should be abolished. In conclusion, the Crown prerogative (and any franchise) to: (a) castellate (i.e. to erect a castle or fortified house); and (b) to levy murage, should be abolished;

- $\quad$ Road Tolls- Tolls Thorough \& Traverse. In medieval times, it was possible for the Crown to franchise to others its right to maintain, and repair, highways (roads). Also, to levy a toll in respect of the same. Thus, there was toll thorough which was a toll to maintain (and repair) a public highway - as opposed to where a highway was dedicated by a private landowner for public use which was called toll traverse. ${ }^{281}$ Today, there would appear to be no instance of a lord of the manor (or anyone else) having a Crown franchise to impose road tolls -as opposed to a statutory right to toll. ${ }^{282}$ Not least, since this would be evidenced by toll gates and these had all been removed by late Victorian times. ${ }^{283}$ In conclusion, the Crown prerogative (and any franchise) to levy road tolls should be abolished, since such is now (and should be) statutory;

- Bridge Tolls - Pontage. The Crown, by charter, in early times franchised to persons (including lords of the manor) the right to maintain (and repair) bridges used by the public - as well as impose a toll for the same (it was called pontage), see 20. ${ }^{284}$ However, all public bridges (and tolls) are now governed by statute. That is, the toll is levied by virtue of a general or local Act of Parliament. As it is, there are no tolled bridges in Scotland (they have been abolished since 2008) or in Wales ${ }^{285}$ and those in England are now wholly governed by general ${ }^{286}$ or local Acts ${ }^{287}$ - with one possible exception (Eling Bridge, operated by a local council and not a lord of the manor). Thus, pontage no longer exists. ${ }^{288}$ In conclusion, the Crown prerogative (and any franchise) to levy bridge tolls (pontage) should be abolished - since such is now (and should be) statutory;

- $\quad$ Ferries. In olden times, the Crown operated ferries across major rivers such as the river Thames. ${ }^{289}$ It also franchised its prerogative to operate the same - including the right to levy a toll. Such franchises included some to lords of the manor. Today, ferries have been replaced by bridges in most cases and so they are relatively rare. ${ }^{290}$ However, those that do operate are regulated and are governed by general or local legislation. Or, they are privately operated (not purporting to carry as common carriers). In conclusion, the Crown prerogative (and any franchise) to franchise a ferry (including the right to levya toll) should be abolished - since such is now (and should be) statutory.

It should, also, be noted that franchises could (and can) be lost by non-user. For example, where a ferry had not been operating within the last 50 years or so. ${ }^{291}$ Thus, while the right of a lord of a manor might, theoretically, have a right to operate a ferry (by way of an old Crown grant), if he sought to invoke such a right, today, a court

\footnotetext{
${ }^{279}$ See also Truro Corporation v Reynalds (1832) 8 Bing 275 (131 ER 407). See generally, McBain, n 14(c), pp 74-6.

${ }^{280}$ The first town corporation (commune) was London which was recognised by the Crown in 1189.

${ }^{281}$ For how the king's highway and common (public) highways developed, see McBain,n 14(g), pp 1-107. See also Williams, n 24, pp 299300 .

${ }^{282}$ The Department for Transport (DfT) has a list of such toll roads (Statutory Tolled Undertakings in the UK). Details are also available on websites.

${ }^{283}$ Statutory authorisation is not the same as Crown authorisation (a Crown franchise) since the former is an Act of Parliament while the latter is a Crown grant pursuant to a charter.

${ }^{284}$ McBain, n 14(c), pp 74-6.

${ }^{285}$ The Department for Transport (DfT) has a list of such toll bridges. Details are also available on websites.

${ }^{286}$ See McBain, n 14(c), p 86, n 86.

${ }^{287}$ Ibid. Thus, in England, (old) local legislation still governs the tolling of the following 7 bridges: (a) Aldwark; (b) Dunham; (c) Kingsland/Shrewsbury; (d) Rixton and Warburton; (e) Swinford; (f) Whitchurch; (i) Whitney-on-Wye.

${ }^{288}$ Jessel, n 2, p 250 stated (in 1998) 'Nearly all road bridges which are highways are now the responsibility of the county council, and the lord has no duty to repair and no corresponding right to charge pontage. There may still be a few footbridges over streams where the old rules apply.'

${ }^{289}$ See McBain, n 14(e), pp 301-6.

${ }^{290}$ The Department for Transport (DfT) should have details of all ferries still operating.

${ }^{291}$ Jessel, n 2, p 270 'Franchises can cease to exist in different ways. ..Many manors formerly had franchise of ferry which is a monopoly of the right to carry passengers across a short stretch of water, either a river or an arm of the sea. Because it is essential to commerce, he holder of a ferry who does not keep boats ready and available risks forfeiture for non-use.'
} 
might well hold that such had lapsed through (long) non-user. So too, the position in respect of pontage, murage, tolls thorough and traverse.

In conclusion, the Crown prerogatives (and any franchise, licence) of the right to build a castle or fort should be abolished, as obsolete. Crown prerogatives to levy (and franchise) murage (i.e. a toll to repair, and maintain, castle and defensive walls) should also be abolished as obsolete. So too, the Crown prerogative to levy (and franchise) road - as well as bridge - tolls, since such matters are now governed by legislation. Similarly, the Crown prerogative to levy (and franchise) the right to operate a ferry (as well as to impose any toll for the same) should be abolished.

\section{ABOLISHINGMORE CROWN PREROGATIVES - FAIRS \&MARKETS}

Markets and fairs have been previously discussed, see13. As well as any manorial franchise of the same being abolished, the Crown prerogative to hold any fair or market (as well as any franchise of the same) should be abolished since it seems that all fairs and markets today have (long) been operated pursuant to legislation whether general or local - and that such is more appropriate (indeed, it seems that no fairs or markets in England and Wales are still operating pursuant to local legislation, ${ }^{292}$ general legislation now wholly governs such matters).

In conclusion, the Crown prerogative (and any franchise) to hold a fair or market should be abolished, being obsolete, since general legislation now governs such matters.

\section{ABOLISHING THE HUNDRED \& LORD OF THE HUNDRED}

The hundred (or wapentake) was an administrative unit of government first established in Anglo-Saxon times. ${ }^{293}$ Although hundreds were superceded, in practice, by shire courts and courts leet, they never appear to have been abolished as such ${ }^{294}$ and the title 'lord of the hundred' (one in gross) has, sometimes, been an object of sale. ${ }^{295}$

If hundred courts are abolished, see 11(d), this will not affect either the existence of the hundred as such (redundant as it is as an administrative unit) or the title. Both should be abolished as being of no legal worth today. The only relevance of the hundred today would seem to be with regard to the Parliamentary title, see12(e) and to the requirement in the Forest of Dean that any free miner should live within the hundred of St Briavels, see $\mathrm{n} 208$. Exceptions could be made in these cases, if necessary.

\section{In conclusion, the hundred - and the title 'lord of the hundred' - should be abolished.}

\section{CONCLUSION}

As noted in the first article, much of our land law is antiquated and, also, obsolete. Such prevents the consolidation of legislation as well as makes our land law very confused. This is of no benefit to practising lawyers. Nor to the general public. It is, also, very expensive to the taxpayer. The present article argues for the abolition, or repeal, of the following:

- Norman Tenurial System. The vestiges of this should be abolished so that people no longer hold (technically) their land directly, or indirectly, from the Crown. Abolition will (likely) have no practical effect since: (a) the forms of tenurial service (and any payment in lieu) have long ended; (b) there are no benefits from being a mesne lord or from escheat. A Table summarises the current position for ease of reference, see Appendix B;

- Manorial System. This is not the same as the Norman tenurial system. However, there is a degree of inter-connectedness. Thus, if the tenurial system is abolished, consideration should be given to abolishing the manorial system as well. This can be most easily achieved by abolishing the legal concept of a 'manor'. Such will include: (a) all manorial courts (i.e. courts baron, court customary, courts of ancient demesne, all of which no longer operate); (b) the title 'lord of the manor'; and (c) all

\footnotetext{
${ }^{292}$ For example, the last market in Wales that was governed by local legislation was the Abergavenney livestock market governed by the Abergavenney Improvement Acts 1854-71. It was repealed in 2011. See McBain, n 14(e), p 289, n 92. All other markets in Wales were governed by the Food Act 1984 .

${ }^{293}$ The basic administrative units were the: (a) vill (village, town); (b) hundred; (c) shire; and (d) kingdom. Vills (towns) could be smaller, that is, demi-vills (if 10 freemen lived there), hamlets (if less than 5). See Williams, $n$ 24, pp 42-3. (a)-(c) were administered by reeves (the town reeve, hundred man, shire reeve (sheriff). For trading centres, the reeve was called the port reeve and for fortified towns (burghs) the borough reeve.

${ }^{294}$ Jessel, n 2, p 297 'Hundreds...have not formally been abolished. They were inactive that, when rural and urban district councils were set up under the Local Government Act 1894, it was not thought necessary to abolish any residual local government function of hundreds.'

${ }^{295} \mathrm{Ibid}$ 'The title lord of the hundred is still held by the successors of the lords who originally acquired the jurisdiction as a franchise from the Crown, but the hundred is even more intangible than a manor. It does not carry demesne land or services or sporting or mineral rights or any other matters of value.'
} 
manorial incidents save for Class 3 rights and obligations (see below). A Table summarises the current position for ease of reference, see Appendix C;

- Class 3 Rights- Commonsof Turbary, Estovers, Piscary\& Digging.Any rights to common of: (a) turbary (i.e. to take turf/ peat); and (b) estovers (i.e. to take wood to repair a house or farm equipment or for fuel); (b) piscary (i.e. to fish in manorial waters); and (d) digging (i.e. the right of freeholders and enfranchised copyholders, to dig for minerals on manorial waste land)should be abolished generally on environmental grounds - with a possible saving in respect of Dartmoor, the Forest of Dean and the New Forest, all of which are governed by distinct legislation anyway;

- $\quad$ Class 3 Rights-Mines \&Minerals. Any right of the lord of the manor or a tenant to mines and minerals on manorial waste land should be abolished and the general law apply. If not, such rights should be: (a) subject to renewal; and (b) exclude iron, lead, tin and coal (also, possibly, gravel and sand) on environmental grounds. In any case, specific local customs in respect of tin (tin bounding), lead and coal mining by individuals should be abolished. In the case of the duchy of Cornwall, the Cornwall (No 2) Act 1844 (also, called the Assessionable Manors Act 1844) should be repealed. In conclusion, the general law on mines and mining should now prevail;

- Class 3 Rights - Fairs \& Markets. Any right of a lord of the manor to hold (i.e. to operate) a fair or market should be abolished as well as generally (see below), being obsolete. Legislation should now govern;

- Class 3 Rights - Sporting. Any manorial sporting right of a lord over manorial waste should now be held qua land holder or in gross (where previously so held) and not qua lord of the manor and should be subject to renewal (say, every 10 years);

- Class 3 Rights - Bridges, Sea Walls, Dykes etc. Any obligation of a lord of the manor (or tenant) in respect of these should be abolished;

- Crown Prerogatives - Waifs, Estray, Royal Fish, Treasure Trove. Various Crown prerogatives which were, sometimes, franchised to those in the Norman tenurial system as well as to lords of the manor are long obsolete and should be abolished, viz. (a) waif; (b) estray; (c) royal fish; (c) treasure trove; (d) the right to dig for treasure trove on the land of another;

- Crown Franchises - Roval Swans, Wreck. Any franchise in respect ofroyal swans should be abolished - save in respect of the Thames as well as to certain long-standing franchisees. Any franchise in respect of wreck - which franchise was, sometimes, also given to lords of the manor - should be abolished;

- Crown Prerogatives - Pontage, Murage, Castellation, Operating a Ferry (\&ferry tolls). Various Crown prerogatives (which were, sometimes, franchised) included the right to: (a) impose bridge tolls (pontage); (b) impose road tolls (tolls thorough and toll traverse); (c) castellate (i.e. to construct a castle or fort); (d) repair defensive walls (murage). These should be abolished, being obsolete since legislation now governs such matters.

Abolition of all the above would not be difficult and could be achieved by a Land Reform Act, see Appendix A. 


\section{APPENDIX A: LAND REFORM ACT}

\section{Feudal Land Tenure ${ }^{296}$}

(1) All forms of feudal land tenure (that is, the holding of land in return for providing a feudal service or a payment in lieu) are abolished including, for the avoidance of doubt, frankalmoign and divine service $;^{297}$

(2) Tenure by way of common socage shall become (and be termed) 'ownership' or 'freehold' and the Law of Property Act 1925, s 1(1) shall be amended to state: 'The only estates in land capable of existing, or being created, at law are:

(a) ownership (also, called freehold);

(b) leasehold (formerly, a reference to a term of years absolute).

(3) The following tenurial hierarchy and titles are abolished:

(a) the Crown as lord paramount;

(b) any mesne lordship;

(c) any tenancy in paravail. ${ }^{298}$

(4) All incidents (that is, rights and obligations) of feudal land tenure are abolished, including:

(a) fealty; ; $^{299}$

(b) escheat (and rights of disclaimer pursuant to the Insolvency Act 1986, sections 178 and 315 shall now be treated as bona vacantia); ${ }^{300}$

(c) any quitrent, rent or other payment in lieu of performing the tenurial service. ${ }^{301}$

(5) The Statute of Quia Emptores 1290 is repealed. ${ }^{302}$

\section{Honorary Services ${ }^{303}$}

(1) The following are abolished:

(a) grand sarjeanty, save in relation to any honorary coronation service; ${ }^{304}$

(b) petty sarjeanty.

\section{Abolition of certain Courts ${ }^{305}$}

(1) The following are abolished, all:

(a) courts referred to in the Administration of Justice Act 1977, section 23and schedule 4;

(b) courts of ancient demesne. ${ }^{306}$

\section{Commons of Turbary, Estovers, Piscary and Digging ${ }^{307}$}

\footnotetext{
${ }^{296}$ The word 'tenure' applies to land only. However, 'land tenure' confirms this.

${ }^{297}$ Frankalmoign and divine service could have continued after 1926 in respect ofpriests obliged to perform such services at the time, see $\mathrm{n}$ 81. However, all of such will now have died. It may be noted there was no fealty for frankalmoign.

${ }^{298}$ This comprised the hierarchy of tenurial land holding. Abolishing it enables land to be held absolutely.

${ }^{299}$ Strictly, fealty for common socage still exists, although no oath is ever sought by the Crown or a mesne lord. Homage for common socage was abolished by the Tenures Abolition Act 1660. Abolition of fealty as a tenurial incident will abolish any forfeiture for breach of the same.

${ }^{300}$ See 9.For escheat of manorial land, see s 5.

${ }^{301}$ This section applies to common socage (and, possibly, to frankalmoign) quitrents etc. For manorial rents etc, see 5.

${ }^{302}$ If no tenurial hierarchy remains, then, the subinfeudation of the fee simple (now, ownership) is not possible. Quia Emptores 1290 only dealt with the fee simple and not the fee tail or life estates. Fee tails cannot be granted post-1996, see McBain, n 1, pp 64-6.

303 These cannot be included in s 1 since they are no longer tenurial but honorary.

${ }^{304}$ Grand sarjeanty was abolished by the Tenures Abolition Act 1660 , save as any honorary service, see 7. Petty sarjeanty, a form of common socage, was preserved in an honorary capacity.

${ }^{305}$ This section needs to be set out separately, and not be part of s 5, since the courts referred to in the AJA 1977 s 23 include courts other than manorial courts (i.e. courts baron, courts of ancient demesne and courts customary). If these latter manorial courts are abolished, then, so too, is the right to impose a fine or amercement in respect of the same. Also abolished would be any homage or fealty sworn in these courts, abolishing any forfeiture for breach. Cf. Jessel, n 2, p 290.

${ }^{306}$ These were not covered in Sch 4, pt 1 although some were mentioned in pt 3. They are all now obsolete.
} 
(1) The following are abolished, all commons of:
(a) turbary; ${ }^{308}$
(b) estovers; ${ }^{309}$
(c) piscary; 310
(d) digging. ${ }^{311}$

\section{Manor $^{312}$}

(1) The legal concept of a manor ${ }^{313}$ is abolished, including the following:

(a) the title 'lord of the manor';

(b) save as specified in (2), any manorial incident (that is, any manorial right or obligation), including any manorial:

(i) incident of common socage, ${ }^{314}$ including: (a) fealty; ${ }^{315}$ (b) suit to court; (c) forfeiture; (d) relief; (e) the payment of any quitrent, rent or other sum of money in lieu of performing a manorial service; ${ }^{316}$

(ii) incident of copyhold, including escheat; ${ }^{317}$

(iii) fine, ${ }^{318}$ rentcharge ${ }^{319}$ or rentservice (including any fee farm rent, chief rent, quitrent, customary rent or rent of assize);

(iv) right to appoint a person to an ecclesiastical office or employment;

(v) right to a pew or other part of a church;

(vi) obligation to make, and/or to pay for, any chancel or other repair to a church;

(vii) manorial obligation of a lord of the manor to maintain and repair a sea wall, bridge, dyke, ditch or the like; ${ }^{320}$

(viii) common of piscary (fishery). ${ }^{321}$

\footnotetext{
${ }^{307}$ This abolishes the right generally and not just for manors, since they can exist other than in the manorial context. They should be abolished for environmental reasons (especially in respect of taking turf, furze (i.e. gorse, thorns). Also, because the original purposes for which they were granted (necessity and as a service benefit) no longer apply.

${ }^{308}$ Ibid. This is the common law right to take turf for fuel. An exception might be made for places such as Dartmoor, Forest of Dean, New Forest and Epping Forest. The number of persons availing themselves of this right in practice, today, must be very small and will increasingly reduce in any case.

${ }^{309}$ Ibid. Estovers comprises the common law right to take wood for fuel and for the repair of a house or farm equipment (including a cart). Invaribly, it tended to be restricted to manorial tenants. It should end due to its original purposes (necessity and as a service benefit) no longer applying. An exception might be made for places such as Dartmoor, Forest of Dean, New Forest and Epping Forest. The number of persons availing themselves of this right in practice, today, must be very small and will increasingly reduce in any case.

${ }^{310} \mathrm{Ibid}$. However, this right (at least, originally) was manorial only.

${ }^{311}$ Ibid. However, this right (at least, originally) was manorial only.

${ }^{312}$ If it was decided not abolish the legal concept of a manor, it would be possible to abolish the courts in $\mathrm{s} 3$ but provide that abolition of the same shall not affect the legal definition of a manor. Otherwise, abolition of all courts baron (or the abolition of escheat) will, ipso facto, turn all manors into reputed manors.

${ }^{313}$ An honor (also called a barony) - as well as a subsidiary honour - is a description of a group of manors. Thus, the term would end with any abolition of a manor, see s 9. The Crown and the duchies of Lancaster and Cornwall have honours. See also Jessel, n 2, p 353.

${ }^{314}$ Where common socage (including burgage) is tenurial, any incident (including fealty) will be abolished pursuant to s 1.

${ }^{315}$ Jessel, n 2, p 288 'Fealty is still in theory due from freehold tenants but as they are rare it is never given in practice...Fealty by copyholders was abolished by s 128 and para 1(b) of sch 12 to the Law of Property Act 1922, but would have gone on enfranchisement in any case.'

${ }^{316}$ See 12(b). It should be noted that an advowson (right to appoint a rector) was not a manorial incident as such. Only limited manors (as well as the Crown and certain bishops in certain cases) acquired such an ecclesiastical right. For advowsons, see s 8 .

${ }^{317}$ Copyhold was abolished in 1926 and the only incidents retained appear to be those referred to in 6(a)(i.e. class 3 incidents). Copyhold (unlike common socage) can only be manorial. Escheat to a mesne lord has been abolished, see n 85. However, it can apply to the Crown (and the duchies of Lancaster and Cornwall) in the case of enfranchised copyholds. Ibid.

${ }^{318}$ Fines on the grant (or assignment) of a leasehold were payable in a manorial court and are now nominal. See 12.

${ }^{319}$ This includes any former rent seck, see Sweet, $\mathrm{n} 2$ (rent).

${ }^{320}$ See 20. For the manorial right to hold a market or fair, see $\mathbf{1 3 .}$

${ }^{321}$ Abolition of common of piscary generally is abolished in s 4. However, it may be limited to manorial common of piscary.
} 
(2) The following rights (whether appendant, appurtenant or in gross) over manorial common land shall now be held by the holder of the same, not as lord of the manor or as a tenant (or former tenant), but as the owner of freehold land or in gross (when they were, previously, in gross), that is, rights:
(a) of sporting;
(b) of common of pasture;
(c) to mine and to minerals, subject to (3). ${ }^{322}$

Further, such rights, to exist and to remain valid, must be:

(a) registered pursuant to the Land Registration Act 2002; and

(b) registration must be renewed every 10 years from the first date of registration; also,

(c) any right in (2)(c)to mine, and to the following minerals, is abolished: (i) coal; (ii) tin; (iii) lead; (iv) iron; (v) gravel; ${ }^{323}$ (vii) sand. ${ }^{324}$

(3) The preservation of manorial court rolls shall be as provided in Appendix [ ]. ${ }^{325}$

\section{Abolition of certain Legal Concepts}

(1) The following are abolished:
(a) waif;
(b) estray;
(c) royal fish.

\section{Certain Crown Prerogatives and Franchises}

(1) The following are abolished, the Crown prerogative (and any franchise) to:
(a) levy murage, ${ }^{326}$
(b) levy pontage; ${ }^{327}$
(c) levy toll traverse or toll thorough; ${ }^{328}$
(d) hold a fair or market; ${ }^{329}$
(e) castellate (that is, to build a castle or fortified house) $;^{330}$
(f) treasure trove;
(g) dig for treasure trove on the land of another.

(2) The Crown prerogative to royal swans shall now only apply to the river Thames and its tributaries. Also, any franchise of the same is abolished, save for the following franchises, to the:
(a) Worshipful Company of Vintners (only on the Thames and its tributaries);
(b) Worshipful Company of Dyers (only on the Thames and its tributaries);
(c) swan breeding colony at Abbotsford, Dorest.

(3) The following are abolished, any Crown franchise of:

\footnotetext{
${ }^{322}$ It is suggested that any manorial rights of common to mine or to take minerals (inc. common of digging for freehold and copyhold tenants) should end, see 15. If not, it is suggested that (3) apply, vis-a-vis what minerals may be mined.

${ }^{323}$ Today, there would appear to be no manorial mining of coal, tin, lead and iron and there is no reason why the general law should not apply. The position on gravel is uncertain. The other mineral that tended to be mined by lords of the manor was sand. For mines and mining in the duchy of Cornwall, see s 10.

${ }^{324}$ These comprise all the minerals set out in legal texts (it seems), with the possible exception of mining for loam (compost). It would seem that, presently, there is no manorial mining of (i)-(iv). Also, such cause environmental damage. In the cases of the duchy of Cornwall, Dartmoor, New Forest, Forest of Dean, Epping Forest, separate provision should bemade since tin, lead, iron and coal mining was common there (and coal still is, the case of the Forest of Dean).

${ }^{325}$ Such an Appendix will set out the Law of Property Act 1922, ss 144 \& 144A.

${ }^{326}$ This has been obsolete since the $15^{\text {th }}$ century (comprising a toll repair, and maintain, defensive walls for military purposes).

${ }^{327}$ Crown grants to levy a toll to maintain, and repair, bridges (pontage) ended by the $16^{\text {th }}$ century. All bridge tolls in England today (they do not exist in Scotland or Wales) are imposed by virtue of local, or general, legislation, see 23.

${ }^{328}$ No such tolls (and toll gates) appear to still exist.

${ }^{329}$ No fairs or markets appear to be presently operating by way of a Crown grant, manorial or otherwise.

${ }^{330}$ There is, presently, a prohibition on castellation by the general public, see McBain, $\mathrm{n} 14(\mathrm{~g})$. This should be abolished as being obsolete.
} 
(a) wreck (including flotsam, jetsam, ligan and derelict).;

\section{Advowsons, Tithes, Moduses}

(1) The following (and any payment in lieu in the case of (b) and (c)) are abolished:
(a) any advowson, or other right of patronage in respect of any ecclesiastical office; ${ }^{331}$
(b) tithe;
(c) modus.

(2) The Gifts for Churches Act 1811 is repealed and the Reverter of Sites Act 1977 shall apply to any church gifted pursuant to that Act.

\section{Hundred and Honor}

(1) The following are abolished, the:
(a) hundred and the title 'lord of the hundred'; 332
(b) honor (honour) and the title 'lord of the honor'. 333

\section{Duchy of Cornwall}

(1) The Cornwall (No 2) Act 1844 (also, called the Assessionable Manors Act 1844) is repealed. ${ }^{334}$

\section{New Forest, Forest of Dean, Dartmoor, Epping Forest ${ }^{335}$}

(1) New Forest Acts;

(2) Forest of Dean Acts;

(3) Dartmoor Act Commons Act 1965;

(4) Epping Forest Act 1878.

\section{APPENDIX B:NORMAN LAND TENURE}

The current position in respect of Norman land tenure is as below (reference to the ' 1660 Act' being to the Tenures Abolition Act 1660).

\section{$\underline{\text { Service }}$}

Knight Service

Grand Sarjeanty

Petty Sarjeanty

Frankalmoign

(inc Divine Service)

Common Socage $\underline{\text { Status }}$

Abolished, 1660 Act.

Made honorary, 1660 Act.

Made honorary, 1660 Act.

Abolished, save where extant in 1926

Extant

\section{$\underline{\text { Proposal }}$}

Restrict to coronation services

Abolish.

Obsolete. Abolish.

Extant incidents comprise: (a) fealty (albeit, obsolete); (b) escheat (albeit, ss $178 \& 315$ of the Insolvency Act 1986 are

\footnotetext{
${ }^{331}$ Abolition could be restricted to any advowsons held by a lord of the manor, in which case it should be added to 5 .

${ }^{332}$ This would affect the parliamentary stewardship of the hundreds of Stoke, Desborough or Burnham, see 12(e). Qualification as a free miner involves reference to the hundred of St Briavels, see n 208. Exceptions could be made in these cases.

${ }^{333}$ There would appear to be no honor courts in existence.

${ }^{334}$ This converted conventionary tenants in certain (17) manors into free holders. It also preserved certain rights to mines and minerals. If repealed, the general law on mines and minerals will apply,

${ }^{335}$ In the legislation relating to these, exceptions should be made in the case of commons of turbary, estovers etc.
} 
better treated as bona vacantia not escheat). ${ }^{336}$

\section{APPENDIX C: MANORIAL TENURE}

The current position in respect of manorial tenure is as follows:

$\underline{\text { Status }}$

Lord of the Manor

Freeholder

Enfranchised Copyholder

\section{Incidents}

Class 3 rights to: (a) sporting; (b) minesand minerals; (c) hold a fair or market. Also, (d) - the obligation to maintain bridge, sea wall etc.

(i) Fealty, suit to court, forfeiture to the Lord and relief; (ii) commons of turbary, estovers, piscary \& digging; (iii) common of pasture; (iv) see (d) above; (v) escheat.

Same as (ii)-(iv)

\section{Proposal}

De-link (a). Abolish or de-link (b). Abolish (c) \& (d).
Abolish (i)-(v) save for (iii) which de-link.

\section{Copyright}

Copyright for this article is retained by the author(s), with first publication rights granted to the journal. This is an open-access article distributed under the terms and conditions of the Creative Commons Attribution license (http://creativecommons.org/licenses/by/4.0/).

\footnotetext{
${ }^{336}$ An oath of fealty is never now sought by the Crown (or mesne lords) and, thus, it is obsolete. In the case of ss $178 \& 315$, medieval tenure never made provision for disclaimer (cf. forfeiture). Thus, these are better taken as examples of bona vacantia (there was, also, no company or bankruptcy law in that time). Any common socage tenurial rents (such as burgage rents, quitrents etc.) are now nominal.
} 